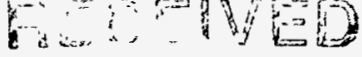

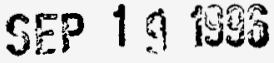 \\ OSTI
}

BNL- 63331

\section{PRODUCED WATER DISCHARGES TO \\ THE GULF OF MEXICO: BACKGROUND INFORMATION FOR ECOLOGICAL RISK ASSESSMENTS}

Anne F. Meinhold, Seymour Holtzman, and Michael P. DePhillips

June 1996

Prepared for

Bartlesville Project Office

United States Department of Energy

Bartlesville, OK

BIOMEDICAL AND ENVIRONMENTAL ASSESSMENT GROUP

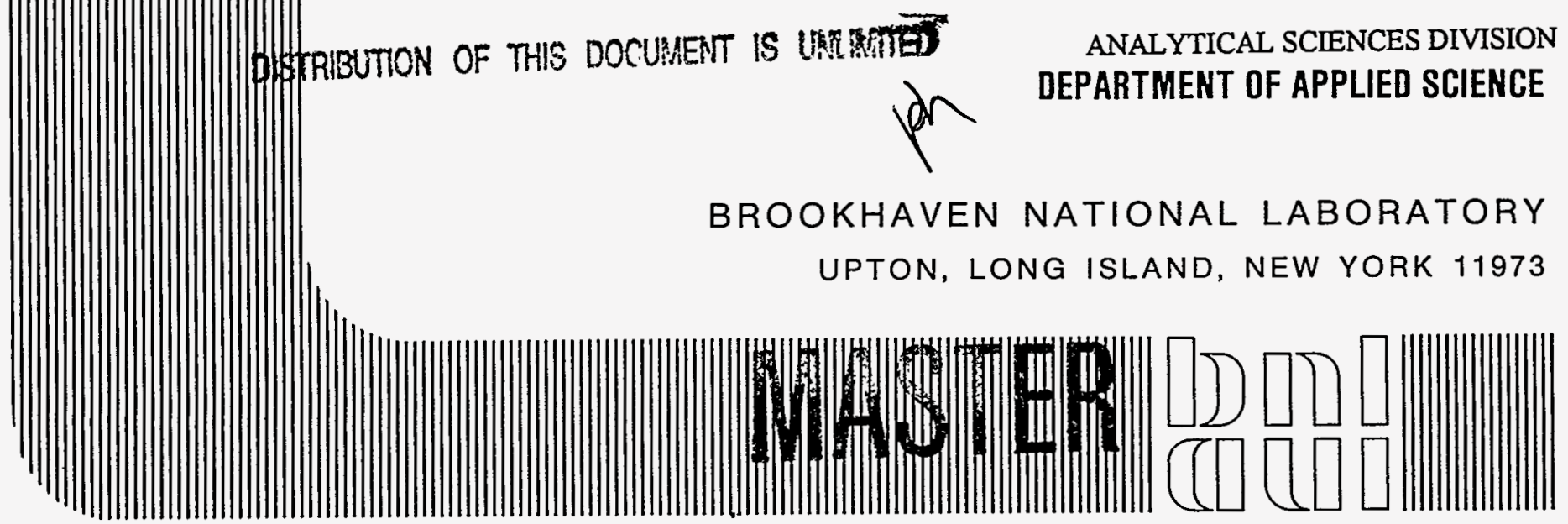




\section{DISCLAIMER}

This report was prepared as an account of work sponsored by an agency of the United States Government. Neither the United States Government nor any agency thereof, nor any of their employees, nor any of their contractors, subcontractors, or their employees, makes any warranty, express or implied, or assumes any legal liability or responsibility for the accuracy, completeness, or usefulness of any information, apparatus, product, or process disclosed, or represents that its use would not infringe privately owned rights. Reference herein to any specific commercial product, process, or service by trade name, trademark, manufacturer, or otherwise, does not necessarily constitute or imply its endorsement, recommendation, or favoring by the United States Government or any agency, contractor, or subcontractor thereof. The views and opinions of authors expressed herein do not necessarily state or reflect those of the United States Government or any agency, contractor or subcontractor thereof. 


\section{PRODUCED WATER DISCHARGES TO THE GULF OF MEXICO: BACKGROUND INFORMATION FOR ECOLOGICAL RISK ASSESSMENTS}

Anne F. Meinhold, Seymour Holtzman, and Michael P. DePhillips

June 1996

Prepared for Bartlesville Project Office United States Department of Energy Bartlesville, OK

BIOMEDICAL AND ENVIRONMENTAL ASSESSMENT GROUP ANALYTICAL SCIENCES DIVISION DEPARTMENT OF APPLIED SCIENCE BROOKHAVEN NATIONAL LABORATORY ASSOCIATED UNIVERSITIES, INC.

Under Contract No. DE-AC02-76CH00016 with the U. S. Department of Energy 


\section{DISCLAIMER}

Portions of this document may be illegible in electronic image products. Images are produced from the best available original document. 


\section{ACKNOWLEDGMENTS}

This work was supported by the United States Department of Energy, Office of Fossil Energy, with guidance from Mr. John Ford as project officer in Fiscal Year 1996 and Dr. Brent Smith in FY 1995. Ms. Sharon Baxter prepared many of the maps that appear in this report. Dr. Leonard D. Hamilton, Dr. Michael Rowe and Dr. Sam Morris reviewed the manuscript and made useful additions and suggestions. 


\section{CONTENTS}

\section{page}

ACKNOWLEDGMENTS .............................................................. i

ACRONYMS..........................................................................

EXECUTIVE SUMMARY ................................................................. xiii

1 INTRODUCTION..................................................................... 1

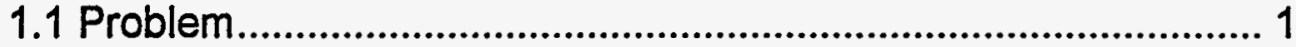

1.2 Risk Assessment........................................................................ 4

1.3 This Report .................................................................... 5

2 ECOLOGICAL RISK ASSESSMENT ........................................ 7

2.1 Introduction .................................................................... 7

2.2 Framework for Ecological Risk Assessment .............................. 7

2.2.1 Problem Formulation.................................................... 7

2.2.2 Analysis Phase - Exposure Assessment.............................. 10

2.2.3 Analysis Phase - Effects Assessment.................................. 10

2.2.4 Risk Characterization..................................................... 11

2.2.5 Risk Management ............................................................... 11

2.3 Methods and Data for Exposure Assessment ........................ 11

2.3.1 Transport and Fate ..................................................... 11

2.3.2 Quantification of Exposure .............................................. 12

2.3.2.1 Estimation of Dose ............................................... 12

2.3.2.2 Internal Exposure ................................................. 13

2.4 Methods and Data for Effects Assessment .................................... 14

2.4.1 Toxicity Testing........................................................ 14

2.4.2 Effects Extrapolation .............................................. 18

2.5 Methods for Risk Characterization ......................................... 20

2.5.1 Compare Exposure and Effects Values ..................... 21

2.5.2 Population and Ecosystem Level Effects .................. 21

2.6 Uncertainty................................................................... 23

2.7 Data for Ecological Risk Assessments for Produced
Water Discharges ........................................................... 24

3 BIOLOGICAL RESOURCES OF THE GULF OF MEXICO ............... 27

3.1 Major Ecosystems ................................................................ 27

3.2 Biota............................................................................ 28

3.3 Commercial and Recreational Fisheries ............................... 29

3.4 Application to Ecological Risk Assessments for Produced Water Discharges ............................................................. 31

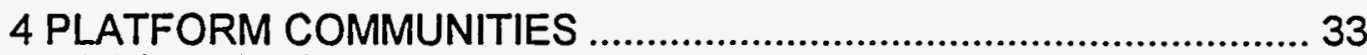

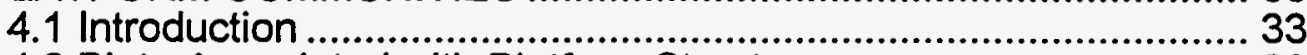

4.2 Biota Associated with Platform Structures ................................ 33

4.3 Conceptual Model .................................................................. 39

4.4 Application to Ecological Risk Assessments for Produced Water Discharges 
5 ENDANGERED SPECIES AND SENSITIVE ECOSYSTEMS

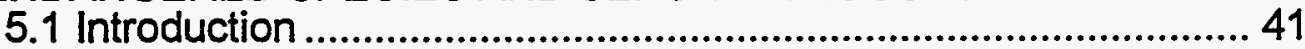

5.2 Endangered Species and Marine Mammals .................................. 41

5.3 Unique and Sensitive Ecosystems................................................ 46

5.4 Application to Ecological Risk Assessments for Produced Water Discharges

6 CHEMICAL/PHYSICAL CHARACTERIZATION OF

PRODUCED WATER ........................................................................ 51

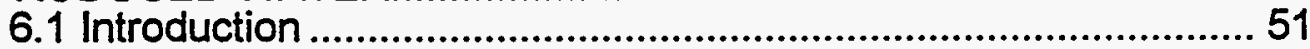

6.2 Conventional Pollutants, Heavy Metals and Organics ................. 51

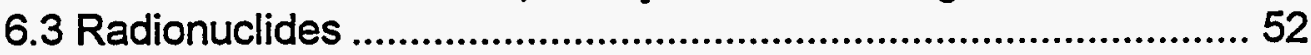

6.4 Discharge Rates................................................................... 52

6.5 Application to Ecological Risk Assessments for Produced Water Discharges ......................................................................... 52

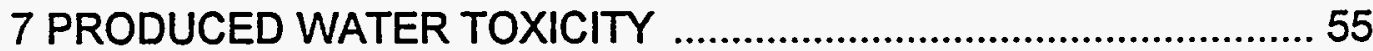

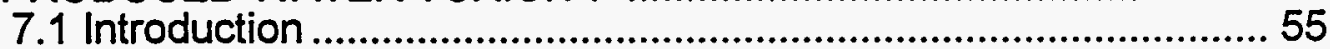

7.2 Laboratory Bioassays............................................................. 55

7.2.1 NPDES Permitting Data ....................................................... 56

7.2.2 The Buccaneer Gas and Oil Field Study.............................. 56

7.2.3 Offshore Operators Committee (1992).................................. 58

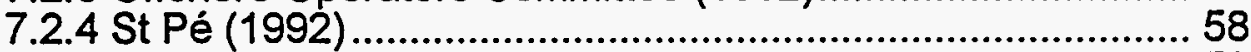

7.2.5 Enviro-Lab (Federal Register, 1992)............................... 59

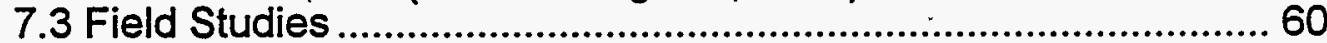

7.4 Toxicity Studies on Sediments Near Outfalls.............................. 61

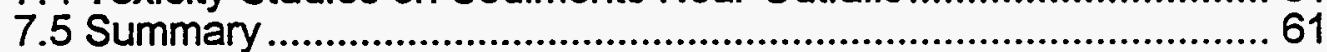

7.6 Application to Ecological Risk Assessments for Produced

Water Discharges

8 BIOACCUMULATION OF MAJOR TOXIC COMPONENTS OF

PRODUCED WATER............................................................................6. 62

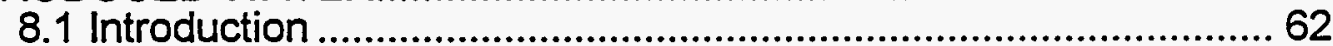

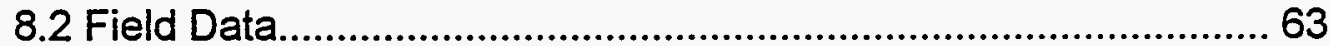

8.2.1 Organic and Hydrocarbon Compounds...............................63 63

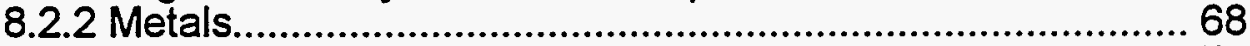

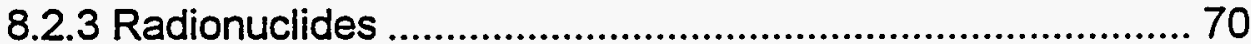

8.3 Bioaccumulation Factors....................................................... 75

8.3.1 Bioaccumulation Factors for Polyaromatic Carbon

Compounds.................................................................... 75

8.3.2 Bioaccumulation Factors for Inorganic and Organic Chemical Toxicants............................................................. 76

8.3.3 Bioaccumulation Factors for Radium ..................................... 76

8.4 Application to Ecological Risk Assessments for Produced

Water Discharges 
9 TOXICITY OF MAJOR INDIVIDUAL CHEMICAL COMPONENTS .... 82

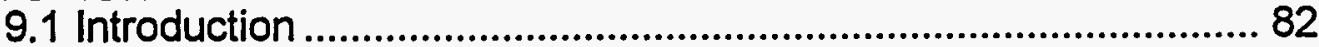

9.2 Toxicity of Chemicals in Water................................................... 82

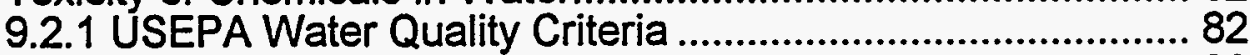

9.2.2 Available Toxicity Data....................................................... 89

9.3 Sediment Chemical Toxicity ....................................................... 89

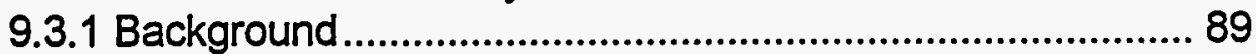

9.3.2 Methods for Developing Sediment Quality Criteria ............. 91

9.3.3 Suggested Sediment Quality Criteria.................................... 93

9.4 Histopathological and Genotoxic Effects in Fish......................... 95

9.5 Application to Ecological Risk Assessments for Produced Water Discharges .......................................................................... 96

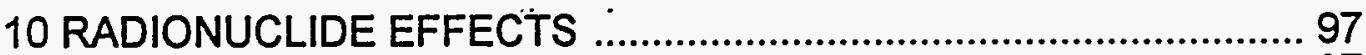

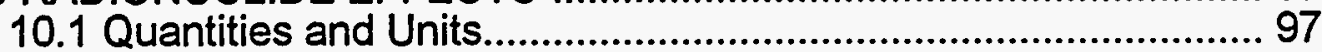

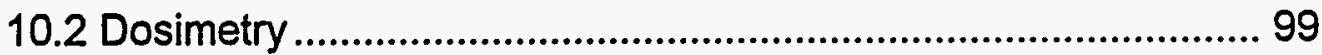

10.2.1 Model Codes and Dose Conversion Factors ................... 99

10.2.2 IAEA (1976) Method....................................................... 100

10.3 Effects on Individuals and Populations .................................. 101

10.4 Application to Ecological Risk Assessments for Produced Water Discharges ................................................................... 103

11 EFFECTS ON BENTHIC COMMUNITIES .................................... 104

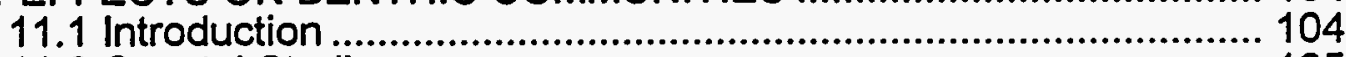

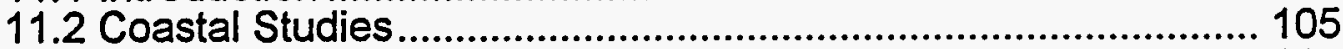

11.3 Offshore Benthic Communities.................................................... 112

11.4 Summary of Benthic Effects .................................................... 115

11.5 Application to Ecological Risk Assessments for Produced Water Discharges ..................................................................... 116

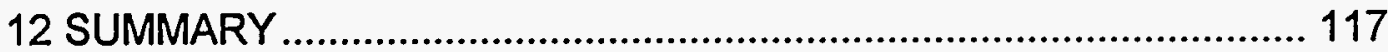

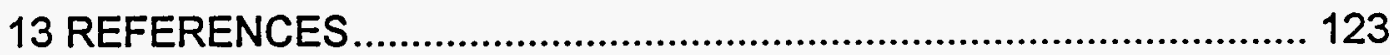

APPENDIX A. Species lists for the Gulf of Mexico.............................. 141 


\section{Figures}

page

1-1. Offshore oil and gas platforms in the Gulf of Mexico ...................... 2

1-2. Coastal produced water discharges in the Gulf of Mexico............. 3

2-1. Framework for ecological risk assessment ................................... 8

4-1. Conceptual model of a platform community.................................. 40

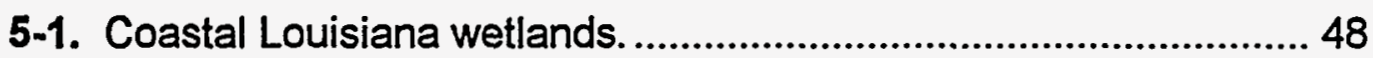

5-2. Topographic features in the Gulf of Mexico ................................ 49

5-3. Chemosynthetic benthic communities in the Gulf of Mexico.......... 50 


\section{Tables}

page

2-1. Uncertainties and their importance in ecological risk assessment (from Smith and Shugart, 1994; adapted from Cothern, 1988)

3-1. Major ecological systems of the Texas-Louisiana continental shelf and upper continental slope (modified from Darnell and Phillips, 1988).

3-2. Composition of catch around oil and gas platforms off Louisiana (modified from Stanley and Wilson, 1990).

4.1. Dominant organisms (by weight) for coastal, offshore and blue water biofouling communities (modified from Darnell and Schmidly, 1988)

5-1. Marine mammals of the central and western Gulf of Mexico (modified from Schmidly and Scarborough, 1990; as cited in MMS ,1993)

5-2. Endangered and threatened species in the northern Gulf of Mexico potentially impacted by produced water discharges (MMS, 1994)

6-1. Ranges of metals and organic contaminant concentrations in produced waters $(\mu \mathrm{g} / \mathrm{l})$

6-2. Radionuclides in produced water discharges in the Gulf of Mexico (pCi/l)

6-3. Produced water discharge rates for coastal and offshore discharges in the Gulf of Mexico 54

7-1. Toxicity data, Louisiana DEQ NPDES Permits 56

7-2. Acute toxicity ( $L C_{50}$ value) for four coastal Louisiana produced water effluents (St Pé, 1990).

7-3. Field bioassay in February 1979 (adapted from Workman and Jones, 1979) 
8-1. Fossil Fuel Pollution Index (FFPI), and concentrations (ppb) of total polycyclic aromatic hydrocarbons (PAH) and total soluble hydrocarbons $(\mathrm{SH})$ in native bivalves at inshore produced water sites and reference sites ${ }^{*}$ (Boesch and Rabalais, 1989a)

8-2. Measured concentrations ( $\mathrm{ppm}$, lipid) of hydrocarbons and PAHs in oysters; controls and 14-day exposures at reference sites and oil production areas (data from Rabalais et al., 1991)

8-3. Measured concentrations (ppm, lipid) of hydrocarbons and PAHs in oysters; controls and 27-day exposures at reference sites and oil production areas (data from Rabalais et al., 1991)

8-4. Measured concentrations ( $\mathrm{ppb}$, wet weight) of PAHs and volatile hydrocarbons in oysters; 30 -day exposures at reference site and oil production areas (data from St. Pé, et al., 1990).

8-5. Comparison of ranges of concentrations of PAH (ppb, wet weight $)^{1}$ from two investigations of produced waters, by deployment of oysters, Crassostrea virginica, in Louisiana coastal waters

8-6. Mean concentrations of alkanes in biota sampled at the Buccanear Oil and Gas Field

8-7. Measured concentrations (ppm, dry weight) of metals in oysters; controls and 14-day exposures at reference sites and oil production areas (data from Rabalais et al., 1991).

8-8. Measured concentrations (ppm, lipid) of metals in oysters; controls and 27-day exposures at reference sites and oil production areas (data from Rabalais et al., 1991).

8-9. Concentration (ppm, dry weight) ranges in three species of finfish, captured in four South Carolina estuaries (abstracted from Matthews, 1994)

8-10 Radium concentrations measured in organisms near the Eugene Island platform 70

8-11. Radium concentrations measured in organisms near the Ship Shoal platform. 
8-12. Radium concentrations measured in organisms sampled from the legs of the South Timbalier platform.

8-13. Radium concentrations measured in organisms sampled in study of coastal produced water discharges

8-14. Radionuclides in blue crab at Golden Meadow 74

8-15. Radionuclides in blue crab and hardhead catfish at Quarantine Bay 74

8-16. Generic bioaccumulation factors for organics and metals. 77

8-17. Estimated bioaccumulation factors for selected trace metals and petroleum components in produced waters 78

8-18. Maximum BCFs from USEPA AQUIRE database for exposure in salt water. 79

8-19. IAEA default bioaccumulation factors for radium 79

8-20. Calculated radium bioaccumulation factors for organisms sampled in the Continental Shelf Associates (1991) study.

9-1. USEPA (USEPA, 1985 and proposed) and LDEQ water quality criteria 85

9-2. Minimum concentrations of contaminants yielding $L_{50} s$ in selected taxa of aquatic organisms in salt water 90

9-3. Proposed sediment quality criteria (from Long et al., 1995) .......... 94

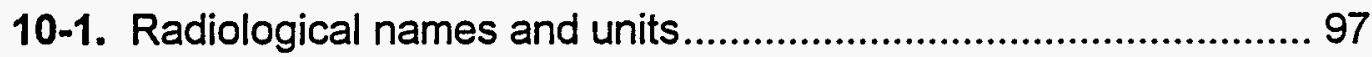

10-2. Prefixes used in radiation protection.......................................... 97

10-3. IAEA dose conversion factors (mSv/hr per $\mathrm{Bq} / \mathrm{m}^{3}$ ).................. 100

11-1. General characteristics of study areas (adapted from Boesch and Rabalais, 1989a). 105 
11-2. Threshold concentrations of chemical constituents in near-bottom waters and surficial sediments at or above which benthic fauna was depressed at Pass Fourchon (adapted from Rabalais et al., 1991). 107

11-3. Threshold concentrations of chemical constituents in surficial sediments at or above benthic fauna was depressed at Bayou Rigaud (adapted from Rabalais et al., 1991). 108

11-4. Threshold concentrations of chemical constituents in surficial sediments at or above benthic fauna was depressed at East Timbalier Island (adapted from Rabalais et al., 1991)

11-5. Threshold concentrations of chemical constituents in surficial sediments at or above benthic fauna was depressed at Eugene Island (adapted from Rabalais et al., 1991). 


\section{ACRONYMS}

AET Apparent Effects Threshold

AF Application Factor

API American Petroleum Institute

AQUIRE Aquatic Toxicity Information Retrieval Database

BAF Bioaccumulation Factor

BAT Best Available Technology Economically Achievable

BCF Bioconcentration Factor

BEAG Biomedical and Environmental Assessment Group

BEDS Biological Effects Database

BGOF Buccanear Gas and Oil Field

BNL Brookhaven National Laboratory

CEAM Center for Exposure Modeling

CORMIX Cornell Mixing Zone Expert System Model

CSA Continental Shelf Associates, Inc.

$E_{50} \quad$ Median Effective Concentration

EIS Environmental Impact Statement

ERL Effects Range Low

ERM Effects Range Median

FFPI Fossil Fuel Pollution Index

FWS Fish and Wildlife Service

IAEA International Atomic Energy Agency

ICRP International Commission on Radiological Protection

IFEM Integrated Fate and Effects Model 
LC $C_{50} \quad$ Median Lethal Concentration

LD $_{50} \quad$ Median Lethal Dose

LDEQ Louisiana Department of Environmental Quality

LOEC Lowest Observed Effects Concentration

LOAEL Lowest Observed Adverse Effect Level

MATC Maximum Acceptable Toxicant Concentration

MFO Mixed Function Oxidase

MMS Minerals Management Service

NEPA National Environmental Policy Act

NCRP National Council on Radiation Protection and Measurements

NMFS National Marine Fisheries Service

NOAA National Oceanic and Atmospheric Administration

NOEC No Observed Effects Concentration

NOEL No Observed Effects Level

NORM Naturally Occurring Radioactive Material

NPDES National Pollution Discharge Elimination System

OEI Offshore Ecology Investigation

OOC Offshore Operators Committee

PAC - Polyaromatic Carbon

PAH Polycyclic Aromatic Hydrocarbon

QF Quality Factor

RBE Relative Biological Effectiveness

SEP Sediment Equilibrium Partitioning

SI International System of Units (Systeme International) 
SWACOM Standard Water Column Model

TDS Total Dissolved Solids

USDOC United States Department of Commerce

USDOE United States Department of Energy

USDOI United States Department of Interior

USEPA United States Environmental Protection Agency 


\section{EXECUTIVE SUMMARY}

\section{Introduction}

Oil and gas production is often accompanied by the production of a saline wastewater, called produced water. In offshore and coastal areas, this wastewater may be discharged to surface water. Produced water may contain a number of contaminants, including oil and grease, organics, heavy metals and radionuclides. Many of these contaminants are toxic to marine organisms at high concentrations.

Environmental impacts associated with discharges of produced water are of concern to regulators at the state and federal levels, the public, environmental interest groups and industry. Most of the current (and projected future) oil and gas platforms in the U.S. are located in the central and western Gulf of Mexico. This area supports economically important commercial and recreational fisheries, as well as unique, socially valued ecosystems, and several endangered and threatened species.

This report reviews ecological risk assessment concepts and methods; describes important biological resources in the Gulf of Mexico of potential concern for produced water impacts; and summarizes data available to estimate exposure and effects of produced water discharges. The emphasis is on data relating to produced water discharges in the central and western Gulf of Mexico, especially in Louisiana. Much of the summarized data and cited literature are relevant to assessments of impacts in other regions. Data describing effects on marine and estuarine fishes, mollusks, crustaceans and benthic invertebrates are emphasized.

This review is part of a series of studies of the health and ecological risks from discharges of produced water to the Gulf of Mexico, supported by the United States Department of Energy (USDOE). These assessments will provide input to regulators in the development of guidelines and permits, and to industry in the use of appropriate discharge practices.

\section{Ecological Risk Assessment}

Early environmental decision-making was based on qualitative descriptions of effects of pollutant discharges on organisms and the environment, with some reliance on the assumption that protection of human health would ensure adequate protection of the environment. Current information and environmental regulations suggest a need for a more quantitative risk-based approach to decision-making for environmental protection. 
USEPA (1992) proposed a framework for ecological risk assessment that includes three phases:

- Problem formulation;

- Analysis (exposure and effects assessment); and

- Risk characterization.

The problem formulation phase identifies the factors to be considered in the assessment, and determines the scope and objectives of the analysis. Specific steps in the problem formulation phase include planning, identification of stressor characteristics, description of the ecosystem potentially at risk, identification of potential ecological effects, endpoint selection, and development of a conceptual model for the assessment.

Selection of endpoints is a critical step in an ecological risk assessment. Selection of assessment endpoints includes identifying the valued components of the environment that are at risk, and developing an operational definition of effects. USEPA recommends that this selection consider ecological relevance, policy goals and societal values, and susceptibility to the stressor (USEPA, 1992).

Approaches to ecological risk assessment were reviewed in the context of USEPA's proposed framework. Methods for exposure assessment include application of transport and fate models, and approaches to the estimation of dose and internal exposure. Methods and data for the effects assessment phase include data from acute and chronic toxicity tests at the individual and population level; and methods to extrapolate effects between species and genera and from acute to chronic effects. Methods for risk characterization include comparing exposure and effects values or distributions, and application of population and ecosystem models.

Major uncertainties in ecological risk assessments come from three fundamental sources: the heterogeneity or stochasticity of natural systems, measurement error, and lack of knowledge. Uncertainties in ecological risk assessments that come from a basic lack of knowledge should be described qualitatively. Other major uncertainties, including natural heterogeneity or stochasticity, and parameter error, can be treated analytically.

A commonly used tool in risk assessment is Monte Carlo analysis. In a Monte Carlo analysis, a sample from the distribution of an input parameter is placed into a simulation run to interact in a model with samples from other input parameters. 


\section{Biological Resources In The Gulf Of Mexico}

A description of the important fisheries resources in the Gulf of Mexico is needed to complete the problem formulation phase of an ecological risk assessment and to identify endpoints for a specific analysis. Additional site or region specific data may be needed for a specific analysis, and species with important social value other than commercial or recreational uses should also be considered.

The Gulf of Mexico includes a wide variety of habitats for marine biota, both in the water column and on the seafloor. Important coastal ecosystems associated with the Gulf of Mexico include extensive wetlands and estuaries. Wetlands provide habitat for a great number and diversity of invertebrates, fish, reptiles, birds and mammals, and are important nursery grounds for many species of fish.

The commercial fishery resources of Texas and Louisiana are of national importance, and the Gulf of Mexico provides almost 20 percent of commercial fish landings in the United States (MMS, 1993). Marine recreational fishing in the Gulf of Mexico accounts for an estimated $\$ 769$ million in sales and employment for over 15,000 people (Sports Fishing Institute, 1987 as cited in MMS, 1993). Recreational fishing takes place from shore or within state waters, as well as offshore from private or charter boats.

Sportfishing in Louisiana and Texas is concentrated around oil and gas structures. Ditton and Auyong (1984) found heavy use of offshore platforms by private recreational fishing boats. Most private recreational boats were bottom fishing, with snapper and seatrout reported most frequently as the major target species. Croaker was reported as a major target species in the Delta Region.

\section{Platform Communities}

A description of the communities associated with coastal and offshore platforms in the Gulf of Mexico is needed to complete the problem formulation phase of an ecological risk assessment and describe the environment at risk. Community descriptions are also required to identify assessment endpoints.

Oil and gas platform structures are colonized by microorganisms, algae, and sessile invertebrates that live attached to the structure and form the biofouling mat. These organisms provide food and habitat for many motile invertebrates and small fishes that live in close association with the biofouling mat. There is also a diverse assemblage of demersal and pelagic fishes associated with the platforms, some of which are residents. The composition of the biofouling community and assemblage of demersal and pelagic fishes associated with platforms varies with distance from shore, water depth, latitude and age of the platform (Gallaway and Lewbel, 1982). 


\section{Endangered Species And Sensitive Ecosystems}

Descriptions of the major ecosystems and biota potentially at risk will support the problem formulation step in an ecological risk assessment. Endangered species and sensitive ecosystems represent unique social values and should be considered in identifying assessment endpoints.

Seven species of baleen whales have been reported in the Gulf of Mexico, but are rare: the northern right whale, blue whale, fin whale, sei whale, Bryde's whale, minke whale and the humpback whale. Five of these species are listed as endangered. Twenty-five species of toothed whales and dolphins have been reported in the Gulf of Mexico. The sperm whale is the only one of the toothed whales and dolphins listed as endangered.

Endangered and threatened species of coastal and marine birds potentially impacted by produced water discharges include the brown pelican, bald eagle, arctic peregrine falcon, piping plover and the whooping crane. One species of fish listed as threatened is potentially affected by produced water discharges the Gulf Sturgeon (a subspecies of the Atlantic sturgeon).

Five species of marine turtles occur in the Gulf of Mexico, and all are listed as threatened or endangered (loggerhead turtle, green turtle, leatherback, hawksbill and Kemp's ridley).

Unique and sensitive biological resources of the Gulf of Mexico include coastal wetlands, the pinnacle trend live-bottom features, topographic features inhabited by hard-bottom benthic communities, and deep water chemosynthetic benthic communities.

\section{Chemical/Physical Characterization Of Produced Water}

Data describing contaminant concentrations and discharge rates of produced water are needed to formulate the problem, identify potential impacts and describe the source term for an ecological risk assessment. Data presented here are limited and additional data derived from permit files and other sources will be needed in a site or area specific assessment.

Produced waters usually have high total dissolved solids (salinity) and total organic carbon, and are low in dissolved oxygen. Other components of potential concern include heavy metals, dissolved and dispersed petroleum hydrocarbons, various treatment chemicals and radionuclides. Contaminants and contaminant concentrations in produced water vary widely, because the characteristics of the saline water and oil in the formation varies and because treatment methods and efficiencies vary over time and space. 
Concentrations of metal discharges in produced waters vary widely. Metals that have been measured in produced waters at concentrations greater than seawater include aluminum, barium, beryllium, cadmium, chromium, copper, iron, lead, manganese, mercury, nickel, silver vanadium and zinc (MMS, 1993).

Produced waters contain petroleum components, with volatile and soluble acidextractable components present in higher concentrations than the heavier components (PAHs) (Middleditch, 1984).

\section{Produced Water Toxicity}

Studies of the toxicity of produced water discharges can be used to assess potential effects on organisms. Problems with using these data include the importance of biocides in causing toxicity, and the change in toxicity that occurs with time and space. Site-specific toxicity tests are preferable to data derived from other sources.

Results of produced water bioassays conducted in the laboratory range from providing evidence of very low toxicities (Middleditch, 1984), to evidence that produced water was highly toxic (Federal Register, 1992). This could be due to differences in the toxicity of the produced water, problems with protocols used in testing, or the presence of biocides in some discharges.

The largest produced water toxicity data base used in permitting applications consists of self-monitoring compliance data required by Louisiana Department of Environmental Quality (LDEQ) discharge permits (Avanti Corporation, 1993). $\mathrm{LC}_{50} \mathrm{~s}$ for mysids ranged from $0.05 \%$ to $>100 \%$ effluent, with a mean 96 hour $\mathrm{LC}_{50}$ of $12.1 \%$. $L C_{50}$ s for sheepshead minnow ranged from $1.17 \%$ to $>100 \%$, with a mean of $27.4 \%$.

\section{Bioaccumulation Of Major Toxic Components Of Produced Waters}

Data describing the bioaccumulation of produced water components can be used to formulate the problem, identify contaminants of potential concern and assess exposure. They can also be used to assess effects, although data relating body burdens to effects are limited. The (bioaccumulation factor) BAF approach is commonly used in both human health and ecological risk assessments, but its reliability may be questionable.

Measurements on field-collected specimens are the preferred method for estimating site-specific bioaccumulation, but they may be fiscally prohibitive (Lee, 1992). There is limited information on bioaccumulation of specific contaminants from produced waters in marine and estuarine organisms in the Gulf of Mexico. Because the data are limited, a BAF modeling approach is often 
used to estimate concentrations of organics, metals and radionuclides in animals.

Only limited data are available for BAFs for organics and metals in saltwater organisms. Bioaccumulation factors in the literature should be reviewed in the context of their relevance and appropriateness for application to a specific organism and specific circumstance. Generic values are often used in screening-models (Strenge and Peterson, 1989) and for organics may be calculated from octanol-water partition coefficients. Bioaccumulation factors for some contaminants in produced water have been estimated by USEPA (Avanti Corporation, 1993) and others are available in the USEPA AQUIRE database (Russom et al., 1991).

\section{Toxicity of Chemical Components of Produced Water}

Data on toxicity of produced water chemical components are needed to support an effects assessment. Limited data are available to describe toxicity to marine organisms native to the Gulf of Mexico, and extrapolating from laboratory studies performed on standard test organisms adds uncertainty to an analysis.

A good place to start in developing the toxicity data needed in an analysis are the USEPA water quality criteria developed to protect saltwater animals as well as other values (USEPA, 1986). Additional data are available in the documents that support these criteria, in the open literature, and in electronic data bases.

USEPA maintains a comprehensive AQUatic toxicity Information REtrieval Database (AQUIRE) that is updated quarterly (Russom et al., 1991). The goal of this data base is to enhance ecological and human health risk assessment processes, by providing comprehensive access to up-to-date available information on aquatic pollutants, including: standardized nomenclature and CAS registry numbers for each chemical; test organism identification by scientific and common names; parameters such as life stage; taxonomic information; test conditions and location; exposure duration and type; water chemistry and chemical analyses; adequacy of controls; effects parameters; and references for each entry.

Another important concern in terms of potential impacts from produced water are effects on animals living on or in the sediment. There are limited data available to describe toxicities to these organisms, but sediment quality criteria have been derived for some contaminants (Long et al., 1995). Limited data also are available to suggest relationships between exposure to contaminants in water and sediment, and genotoxic and histopathologic effects in fish.

Several studies have related particular groups of chemicals to increased incidence of histopathological lesions in fish from saline environments. High 
PAH concentrations in sediments were associated with hepatic lesions (Johnson et al., 1993), and biomarkers (Goksøyr et al., 1994) in marine fishes.

\section{Radionuclide Effects}

An aquatic organism may be irradiated externally by radionuclides in water and sediment, and internally by radionuclides taken into the body by ingestion or direct absorption. Most incorporated radionuclides are differentially distributed among the organs and tissues of the organism.

NCRP (1991) reviewed several models for estimating dose to aquatic animals based on concentrations in water. Models described include CRITR (Soldat et al., 1974), EXREM III, and BIORAD (Trubey and Kaye, 1973). IAEA (1976) presents a method for estimating the dose to aquatic organisms for radionuclides in water, sediment and accumulated in tissue.

IAEA (1988) developed dose conversion factors that relate the radiation exposure of an organism to a unit concentration of the radionuclide in the water in which the organism lives. These dose conversion factors are based on models using assumptions concerning the bioaccumulation factor, sorption coefficient $\left(K_{d}\right)$, and the sizes and shapes of the animals (see IAEA, 1988). These factors may be useful for screening purposes.

Exposure to ionizing radiation can result in injury at the molecular, cellular and whole body levels. Most studies of the effects of radiation on aquatic organisms are concerned with the induction of deterministic, somatic effects. These effects include increases in mortality and pathophysiological, developmental and reproductive effects. There is little information available concerning induction of cancer and genetic effects.

The National Council on Radiation Protection and Measurements recently reviewed the literature on the effects of ionizing radiation on aquatic organisms, and derived reference levels that would protect aquatic populations (NCRP, 1991). NCRP (1991) suggested a reference dose rate of $10 \mathrm{mGy} / \mathrm{d}$ to protect aquatic populations. NCRP also suggested a detailed assessment if an initial analysis results in estimated dose rate above $2.4 \mathrm{mGy} / \mathrm{d}$.

IAEA (1988) came to similar conclusions, but expressed their reference levels in terms of dose equivalent rather than absorbed dose. IAEA (1988) concluded that: 
- increased mortality is expected above $10 \mathrm{mSv} / \mathrm{hr}(240 \mathrm{mSv} / \mathrm{d})$;

- reduced reproductive success may occur between 1 and $10 \mathrm{mSv} / \mathrm{hr}$ (24$240 \mathrm{mSv} / \mathrm{d})$;

- some somatic effects which would be eliminated by natural selection could occur between 0.004 and $1 \mathrm{mSv} / \mathrm{hr}(0.1-24 \mathrm{mSv} / \mathrm{d})$; and

- no adverse effects are expected below background levels of $0.004 \mathrm{mSv} / \mathrm{hr}$ $(0.1 \mathrm{mSv} / \mathrm{d})$.

\section{Effects On Benthic Communities}

Site-specific assessments of benthic effects from produced water discharges may have limited application for assessments at other sites. However, available studies do provide estimates of threshold levels for effects useful in the development of the problem formulation phase of an ecological risk assessment for produced water discharges.

Effects of platforms and platform discharges on benthic communities can vary from reductions in populations and diversity to increases in populations and diversity. This variation includes an increase in diversity at the expense of preexisting species, or an increase in numbers of particular species while total diversity declines. Some of these results are attributable to the introduction of a new structure (i.e., the platform), as well as the accumulation of contaminants in sediments. In the latter case relatively low levels of contaminants may increase populations (hormesis) of opportunistic species that can either metabolically adapt to the contaminants, or compensate for toxic effects on particular lifestages by increases of more resistant stages in the populations.

A number of studies have shown differences in benthic communities with distance from platforms discharging produced water. This was particularly true for coastal sites, in contrast to offshore areas. Although some studies found correlations between the number of species and individuals and the chemical constituents in the near bottom waters or surficial sediments, the findings were site specific and not consistent across all studies. Some studies found little or no disturbance in the benthic communities. Results from studies which found a correlation would be difficult to use for predicting effects, because it is not clear whether the effect was due to periodic contact with toxic substrates in the produced water, substrate disturbance due to currents eddying around the platform leg and removing the substrate, or some other confounding factor (Harper et al., 1981). 


\section{References}

Avanti Corporation, 1993, Ocean Discharge Criteria Evaluation for the NPDES General Permit For the Western Gulf of Mexico OCS, prepared for the United States Environmental Protection Agency, Water Management Division, Region VI.

Ditton, R.B. and J. Auyong, 1984, Fishing Offshore Platforms, Central Gulf of Mexico, An Analysis of Recreational and Commercial Fishing Use at 164 Major Offshore Petroleum Structures, Minerals Management Service, Metairie, LA, MMS-84-0006.

Federal Register, 1992, "Environmental Protection Agency, Final NPDES General Permit for the Western Gulf of Mexico Outer Continental Shelf", Federal Register 58:224:54642-54671.

Gallaway, B.J. and G.S. Lewbel, 1982, The Ecology of Petroleum Platforms in the Northwestenr Gulf of Mexico: A Community Profile, U.S. Fish and Wildlife Service, Office of Biological Services, Washington, D.C., FWS/OBS-82/27, Bureau of Land Management, Gulf of Mexico OCS Regional Office, Open-File Report 82-03.

Goksøyr, A., J. Beyer, A. M. Husoy, H. E. Larsen, K. Westrheim and S. Wilhelmsen, 1994, "Accumulation and Effects of Aromatic and Chlorinated Hydrocarbons in Juvenile Atlantic cod (Gadus morhua) Caged in a Polluted Fjord (Sørfjorden, Norway), Aquatic Toxicology 29:21-35.

Harper, D.E. and D.C. Potts, 1981, "Distribution and Abundance of Macrobenthic and Meiobenthic Organisms", pp 133-177 in B.S. Middleditch (ed.)

Environmental Effects of Offshore Oil Production, the Buccaneer Gas and Oil Field Study, Plenum Press, NY

IAEA, 1976, Effects of lonizing Radiation on Aquatic Organisms and Ecosystems, Technical Report Series No. 172, International Atomic Energy Agency, Vienna:

IAEA, 1988, Assessing the Impact of Deep Sea Disposal of Low Level Radioactive Waste on Living Marine Resources, Technical Reports Series No. 288, International Atomic Energy Agency, Vienna.

Johnson, L. L., C. M. Stehr, O.P. Olson, M.S. Myers, S.M. Pierce, C.A. Wigren, B.B. McCain and U. Varanasi, 1993, "Chemical Contaminants and Hepatic Lesions in Winter Flounder (Pleuronectes americanus) From the Northeast Coast of the United States", Environmental Science and Technology 27:2759-2771. 
Lee, H., II, 1992,. "Models, Muddles, and Mud: Predicting Bioaccumulation of Sediment-Associated Pollutants", Chapter 12 in : G. A. Burton Jr., ed., Sediment Toxicity Assessment, Lewis Publishers, Boca Raton FL pp. 267 293.

Long, E. R., D. D. Macdonald, S. L. Smith, F. D. Calder, 1995, "Incidence of Adverse Biological Effects Within Ranges of Chemical Concentrations in Marine and Estuarine Sediments", Environmental Management 19:81-97.

Middleditch, B.S., 1984, Ecological Effects of Produced Water Discharges From Offshore Oil and Gas Production Platforms, Final Report on API Project No. 248, American Petroleum Institute, Washington, D.C.

MMS, 1993, Gulf of Mexico Sales 147 and 150: Central and Western Planning Areas, Final Environmental Impact Statement, Volumes I, II, United States Department of the Interior, Minerals Management Service, New Orleans, LA, OCS EIS/EA MMS 93-0065.

NCRP, 1991, Effects of lonizing Radiation on Aquatic Organisms, NCRP Report No. 109, National Council on Radiation Protection and Measurements, Bethesda, MD.

Russom, C. L. and E. B. Anderson, 1991, "Aster in Integration of the Aquire Data Base and the QSAR System For Use in Ecological Risk Assessments", Science Of The Total Environment 109:667-670.

Soldat, J.K., N.M. Robinson and D.A. Baker, 1974, Models and Computer Codes For Evaluating Environmental Radiation Doses, BNWL-1754, Battelle Pacific Northwest Laboratories, Richland, WA.

Sports Fishing Institute, 1987, Number of Paid Fishing License Holders, License Sales, and Cost to Fishermen, Fiscal Year 1986, Bulletin No. 387, Washington, D.C. (as cited in MMS, 1993).

Strenge, D.L. and S.R. Peterson, 1989, Chemical Data Bases for the Multimedia Environmental Pollutant Assessment System (MEPAS): Version 1, PNL7145, Pacific Northwest Laboratory, Richland, WA.

Trubey, D.K., and S.V. Kaye, 1973, The EXREM III Computer Code For Estimating External Radiation Doses to Populations From Environmental Releases, ORNL-TM-4322, Oak Ridge National Laboratory, Oak Ridge, TN. 
USEPA, 1986, Quality Criteria for Water, Office of Water Regulations and Standards, United States Environmental Protection Agency, Washington, D.C., EPA4440/5-86/001, NTIS PB87-226759.

USEPA, 1992, Framework for Ecological Risk Assessment, Office of Research and Development, United States Environmental Protection Agency, Washington, D.C., EPA/630/R-92/001. 


\section{INTRODUCTION}

\subsection{Problem}

Oil and gas production is often accompanied by the production of a saline wastewater, called produced water. In offshore and coastal areas, this wastewater may be discharged to surface water. Produced water may contain a number of contaminants, including oil and grease, organics, heavy metals and radionuclides.

Environmental impacts associated with discharges of produced water are of concern to regulators at the state and federal levels, the public, environmental interest groups and industry. Most of the current (and projected future) oil and gas platforms in the U.S. are located in the central and western Gulf of Mexico (Louisiana and Texas; Figures 1-1, 1-2). This area supports economically important commercial and recreational fisheries, as well as unique, socially valued ecosystems and several endangered and threatened species.

Most of the contaminants discharged in produced water occur naturally in the geologic reservoir along with the oil and gas. Many of the contaminants are toxic to marine organisms at high concentrations. Some produced waters also contain added biocides or other treatment chemicals that may be toxic to aquatic organisms.

In offshore environments produced water is diluted so rapidly that contaminants cannot be detected in the water column or sediment, even a few meters from the outfall, and effects on marine life are likely to be minimal. In shallower, coastal environments, contaminants have been detected in water, sediment and organisms several hundred meters from the discharge. Effects on benthic organisms in shallow coastal settings and on organisms in the biofouling mat close to discharge points have been documented (Boesch and Rabalais, 1989a; Gallaway et al., 1981a).

This report is part of a series of studies of the health and ecological risks from discharges of produced water to the Gulf of Mexico, supported by the United States Department of Energy (USDOE). These assessments will provide input to regulators in the development of guidelines and permits, and to industry in the development and application of appropriate discharge practices. 


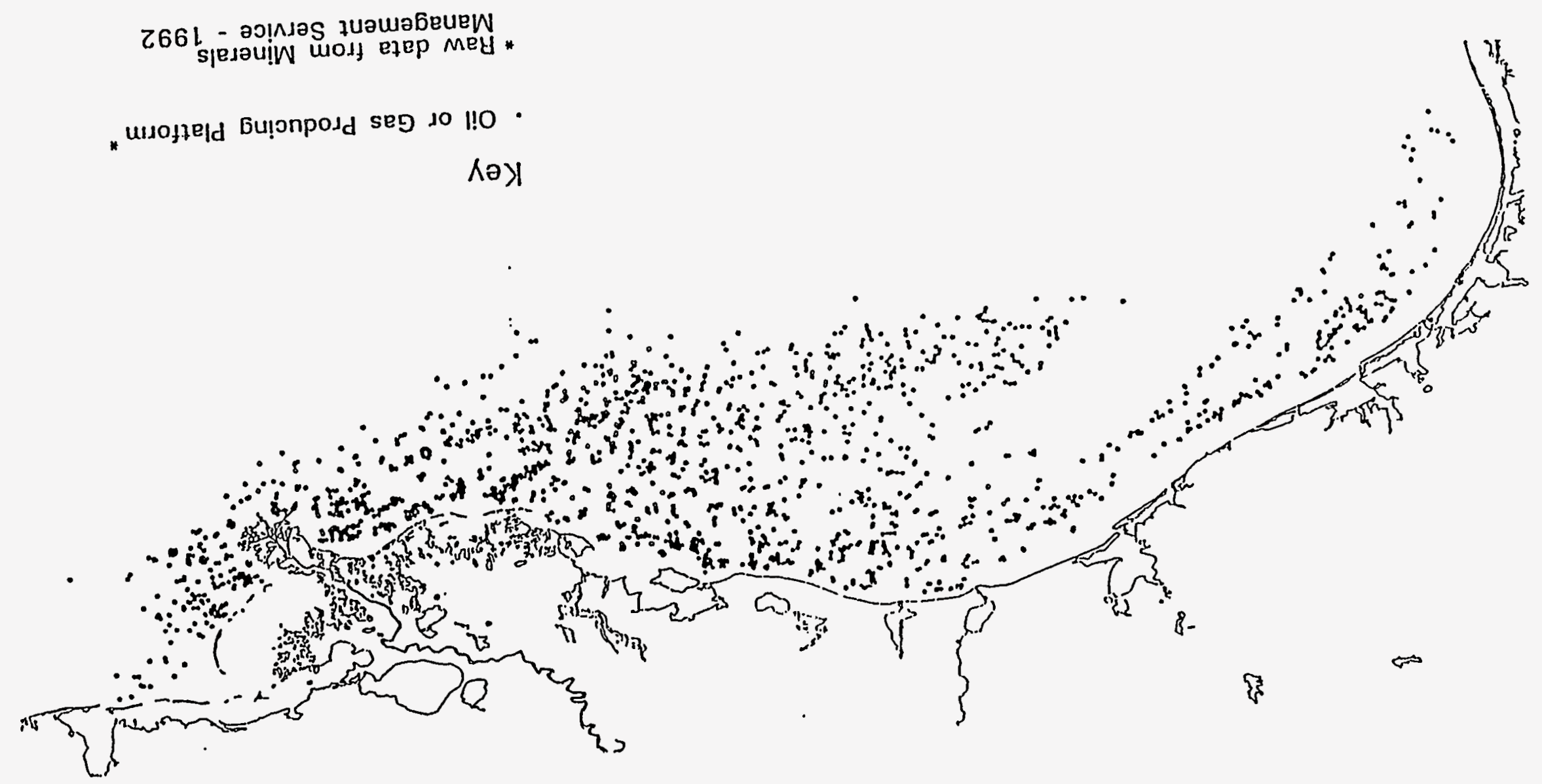

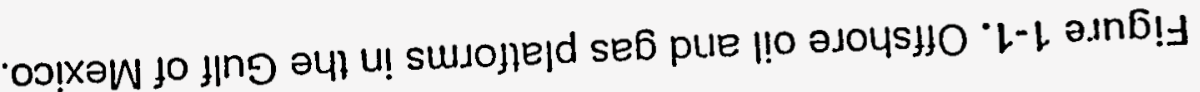




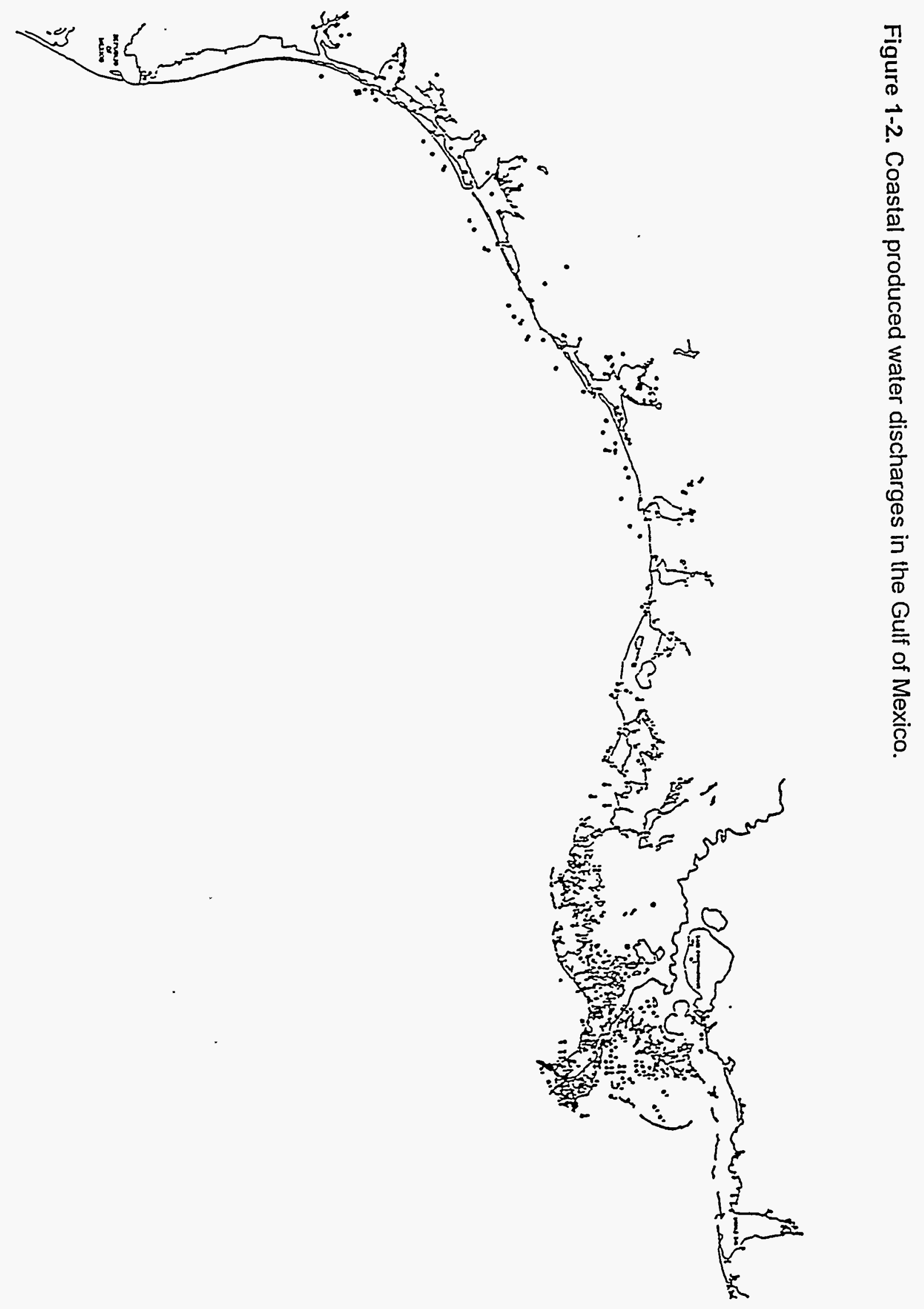




\subsection{Risk Assessment}

Early environmental decision-making was based on qualitative descriptions of effects of pollutant discharges on organisms and the environment, with some reliance on the assumption that protection of human health would ensure adequate protection of the environment. Current information and environmental regulations suggest a need for a more quantitative risk-based approach to decision-making for environmental protection.

"Risk assessment can be defined as the process of assigning magnitudes and probabilities to the adverse effects of human activity or natural catastrophes" (Suter, 1993a). Risk management is the process of decision-making concerning risks - environmental regulation is a form of risk management. Risk assessments provide risk managers with the scientific information needed to balance the degree of risk permitted against competing risks and the cost of risk reduction.

Risk assessment is useful in environmental decision-making because it (Suter, 1993a):

- Provides a quantitative basis for comparing and prioritizing risks;

- Provides a systematic means of improving the understanding of risks;

- Acknowledges the inherent uncertainties in predicting future environmental states;

- Estimates clear and consistent endpoints; and

- Clearly separates the scientific process of estimating the risks (risk assessment) from the process of choosing among alternatives and determining the acceptability of risk (risk management).

The general paradigm developed for assessment of human health risks is now being applied to the estimation of the risks to the environment. The field is new and definitions have not been standardized. For the purposes of this report, "environmental risk assessment" refers to an assessment of the risks to man from contaminants in air, water, soil or food. "Ecological risk assessment" refers to an assessment of risks to the natural environment (Suter, 1993a). The receptors or values of concern in an ecological risk assessment may range from individual organisms to entire ecosystems and fundamental ecological processes. 
The most commonly used framework for human health risk assessment includes the following four phases (NRC, 1983):

- Hazard identification;

- Dose-response assessment;

- Exposure assessment; and

- Risk characterization.

Human health risks are described as the probability of an adverse health effect (e.g., cancer death or toxic effect) occurring in an individual in an exposed population, or the number of health effects expected in the population (individual and population risk). A major characteristic of a risk analysis is that risks are described in terms of probabilities of effects, and uncertainties are explicitly considered in both the analysis and the expression of its result.

With some modifications and additional uncertainties, this framework can be applied to ecological assessments. Because of the number of different species in a community and the complexity of inter-species interactions and basic ecological processes, the level of organization for which the assessment is performed can vary widely (individual, population, community, ecosystem), and the potential endpoints for the assessment are many (death, acute or chronic toxicity, reproductive or developmental effects, disruption of basic processes). USEPA (1992) has proposed a framework for ecological risk assessment that includes three phases:

- Problem formulation;

- Analysis (exposure and effects assessment); and

- Risk characterization.

\subsection{This Report}

This report presents a summary review of the data available to support both traditional qualitative assessments and more quantitative ecological risk assessments of produced water impacts. The emphasis is on data relating to produced water discharges in the central and western Gulf of Mexico, especially in Louisiana. Much of the summarized data and cited literature is relevant to assessments of impacts in other regions. Data describing effects on marine and estuarine fishes, mollusks, crustaceans and benthic invertebrates are emphasized. Data for macroalgae, zooplankton and phytoplankton, and basic ecological processes are not as readily available or as easily applied in an assessment.

This report does not present an impact analysis or ecological risk assessment. Environmental assessments relating to subsets of produced water discharges in the Gulf of Mexico (e.g., discharges in open Louisiana bays, offshore 
discharges) are being developed using the data and information presented here, combined with data collected in a field study conducted by the USDOE and results of environmental transport and exposure modeling.

Not all data or models needed in a specific ecological risk assessment are presented here. The intent of this report is to summarize data available for the Gulf of Mexico, review more generic data, describe and document additional data sources, and introduce the concepts and methods of ecological risk assessment.

Section 2 reviews important ecological risk assessment concepts and methods. Sections 3 through 5 describe the important biological resources in the Gulf of Mexico of potential concern for produced water impacts. These resources include fish and shellfish resources, platform communities, endangered and threatened species, and sensitive and unique ecosystems.

Sections 6 through 11 summarize data available to estimate exposure and effects of produced water discharges including:

- Produced water characteristics;

- Toxicity studies of produced waters;

- Bioaccumulation of produced water components;

- Toxicity studies of produced water components and USEPA water quality criteria;

- Sediment chemical toxicity and sediment quality criteria;

- Radionuclide effects; and

- Field studies of effects on benthic communities. 


\section{ECOLOGICAL RISK ASSESSMENT}

\subsection{Introduction}

Ecological risk assessment is a relatively new field, but regulatory requirements and the desire to improve the bases for environmental decision-making have accelerated its development. Several books summarizing various approaches to risk assessment are available (Suter, 1993b; Bartell et al., 1992; Calbrese and Baldwin, 1993), and USEPA has recently developed a framework for ecological risk assessment (USEPA, 1992).

As used here, "ecological risk assessment" is the study of risks to the natural environment. The objective of ecological risk assessment is to use available toxicological data to estimate the probability of some specific effect on individual organisms, natural populations, communities or ecosystems. An important feature of risk assessment is "the explicit, quantitative consideration of uncertainties in the analysis and the expression of the final estimated effects as a probability" (Bartell et al., 1992). This quantitative result is the goal of an ecological risk assessment, but in practice assessments are often deterministic or qualitative (USEPA, 1992).

\subsection{Framework for Ecological Risk Assessment}

Several similar frameworks for ecological risk assessment have been suggested (Suter, 1993c; USEPA, 1992). All of these frameworks are derived from the human health risk assessment paradigm suggested by the National Research Council (NRC, 1983). USEPA (1992; 1994) developed a framework for ecological risk assessment composed of three phases: problem formulation, analysis, and risk characterization.

Figure 2-1 outlines the steps in an ecological risk assessment as described by USEPA (1992). These steps are described in more detail below (summarized from USEPA, 1992; Suter, 1993c).

\subsubsection{Problem Formulation}

The problem formulation phase identifies the factors to be considered in the assessment, and determines the scope and objectives of the analysis. This phase includes the preliminary data gathering and conceptual development needed to define the problem. Specific steps in the problem formulation phase include planning, identification of stressor characteristics, description of the ecosystem potentially at risk, identification of potential ecological effects, endpoint selection, and development of a conceptual model for the assessment. These steps are not independent of one another, and the decisions and information gathered in each step may influence the others. 
Figure 2-1. Framework for ecological risk assessment (from USEPA, 1992).

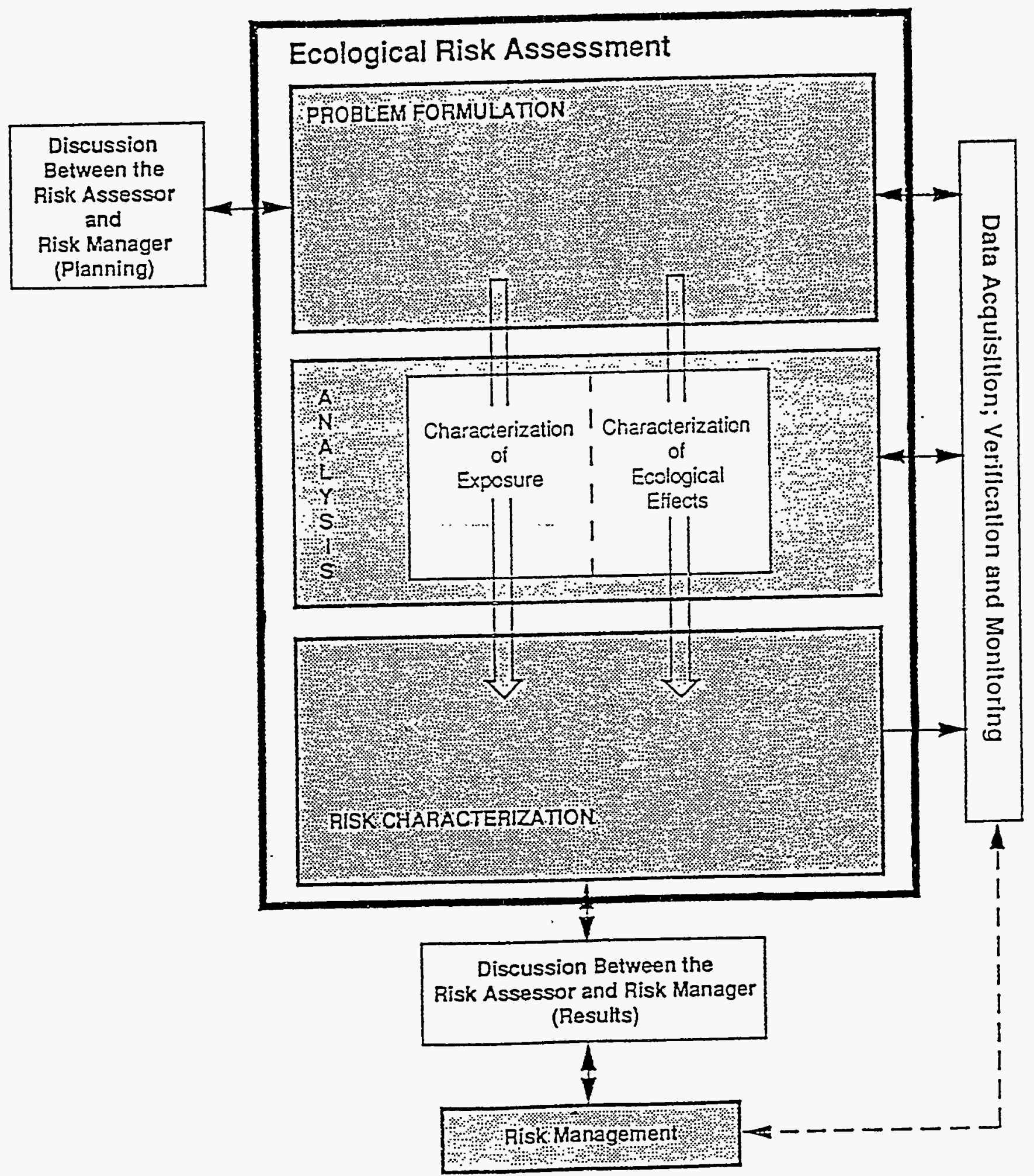




\section{Planning}

This step in the problem formulation phase involves discussion with risk managers to ensure that risk assessments will be relevant to regulatory needs and public concerns. Risk assessment and risk management are separate processes, but interaction with regulators and other stakeholders at this early stage in the process will support the development of relevant assessments.

\section{Stressor Characteristics}

Identification of stressor characteristics includes identifying the potential chemical and physical stressors of concern. In this step, source terms are described in terms of concentration or magnitude, duration, frequency, and spatial scale. Source terms may be estimated directly from emissions data, or derived using transport models and monitoring data.

\section{Ecosystem Potentially at Risk}

This step involves describing the ecosystem potentially at risk from the identified stressor(s). Properties of the ecosystem to be considered include physical aspects of the environment, and ecosystem structure and function.

\section{Ecological Effects}

This step is a preliminary assessment of available data on ecological effects to help focus the assessment on important stressors and ecosystem components.

\section{Endpoint Selection}

Selection of endpoints is a critical step in an ecological risk assessment. An assessment endpoint is a formal expression of the environmental values to be protected (Suter and Barnthouse, 1993). Selection of assessment endpoints includes identifying the valued components of the environment that are at risk, and developing an operational definition of effects.

USEPA recommends that this selection consider ecological relevance, policy goals and societal values, and susceptibility to the stressor (USEPA, 1992). Suter and Barnthouse (1993) make similar recommendations and give five criteria for an assessment endpoint: societal relevance, biological relevance, unambiguous operational definition, accessibility to prediction and measurement, and susceptibility to the hazardous agent.

There is a distinction between assessment endpoints and measurement endpoints. Measurement endpoints are an expression of the results of toxicity tests or field monitoring studies. Assessment endpoints refer to effects on 
populations or ecosystems - things that usually cannot be measured and must be derived by extrapolation from measurement endpoints. Measurement endpoints should be selected on the basis of how well they represent the assessment endpoint.

\section{Conceptual Model}

This is the development of the planned assessment approach. The conceptual model " $(1)$ describes how a given stressor might affect the ecological components in the environment; (2) describes the relationships among the assessment and measurement endpoints, the data required, and the methodologies that will be used to analyze the data and (3) summarizes the steps that will be taken to ensure that laboratory or field data collected for the assessment will be sufficient to achieve the intended objectives" (Barnthouse and Brown, 1994). In the conceptual model, possible exposure scenarios are described, and a series of hypotheses are developed about how the stressor might affect the ecosystem at risk.

\subsubsection{Analysis Phase -- Exposure Assessment}

In the exposure assessment environmental concentrations of the contaminant are described, and exposure of the organisms and ecosystems of concern are estimated. The exposure assessment estimates the transport of the contaminant through the environment, including its transformation and uptake by organisms. Much of the effort in an exposure assessment involves using models to estimate concentrations of contaminants in various media. Estimates of exposure or dose to the endpoint organisms or systems are then developed. The rates of exposure derived in the exposure assessment must be provided in units compatible with the dose-response data developed in the effects assessment. Methods and data used in exposure assessment are described in more detail in section 2.3.

\subsubsection{Analysis Phase -- Effects Assessment}

The effects assessment determines the relationship between exposure to the contaminant and effects on the measurement endpoint. The effects assessment is usually based on the results of toxicity studies. These results are extrapolated to relate the effects on individual organisms to effects on populations, communities and ecosystems. Most effects data for ecological risk assessment are in terms of external exposure in air, soil or water. For mammals and birds, intake and uptake may be used, and internal dose or body burdens estimated. Section 2.4 describes data and statistical extrapolation approaches that may be used in an effects assessment. 


\subsubsection{Risk Characterization}

The risk characterization phase integrates the estimates of exposure and doseresponse relationships, developed in the analysis phase, to produce an estimate of the risk to the identified assessment endpoint. Risk characterization also involves describing the analysis to the risk manager, and discussing the uncertainties associated with the analysis and their implication for the results. Approaches to risk characterization are discussed in section 2.5 .

\subsubsection{Risk Management}

Risk management decisions are made based on the results of the ecological risk assessment. Risk management uses results of the risk assessment to support decisions relating to acceptable risks from environmental discharges.

Regulatory agencies involved in standard setting and regulation development are engaged in risk management. The goal should be to minimize risks without undermining other societal values. A risk assessment should be performed independently of risk management, but the needs and concerns of risk managers should be considered in the design of the risk assessment to ensure that the results are relevant, useable, and understandable to risk managers.

\subsection{Methods and Data for Exposure Assessment}

Exposure assessment comprises two major efforts: an analysis of the transport and fate of the stressor in the environment; and quantification of the exposure of the identified receptor(s) to the contaminant.

\subsubsection{Transport and Fate}

This part of exposure assessment involves translating a source term into estimates of concentration in environmental media. Models are used to simulate transport, dilution, transformation, degradation and partitioning between media, and to generate predictions of the temporal and spatial dynamics of concentration (Suter, 1993c). The input data to these transport models include release rates, chemical and physical characteristics of the pollutant, and characteristics of the receiving environments.

Mackay and Paterson (1993) and Suter et al. (1994) discuss the application of transport models to ecological risk assessment. Models used in human health risk assessment and in assessments for regulatory purposes are applicable. Compilations of model codes are available from the USEPA Center for Exposure Modeling (CEAM; Bouchard et al., 1995), and other reviews of available codes have been published (Moskowitz et al., 19.95). 
Two models of specific interest to the modeling of produced water discharges in the Gulf of Mexico include the Offshore Operators Committee Model (OOC) and the USEPA Cornell Mixing Zone Expert System model (CORMIX).

The OOC model was developed by the Offshore Operators Committee (OOC) and Exxon Production Research Company to predict the initial fate of drilling mud and cuttings to the marine environment (Brandsma and Sauer, 1983a, 1983b; O'Reilly et al., 1988; Brandsma et al., 1992). The model was modified to allow prediction of the initial dynamics and passive diffusion of produced waters.

The OOC model simulates the descent of a jet of discharged material through the water column, dynamic collapse as the material spreads out on the bottom or within the water column, and passive diffusion. Currents can be variable in three dimensions, density profiles can change with time, and the model can incorporate variable depths and land boundaries. The $00 \mathrm{C}$ model has been validated by comparing model predictions to laboratory and field observations (O'Reilly et al., 1988; Brandșma et al., 1992).

The CORMIX model (Doneker and Jirka, 1990) may be used for the prediction of aqueous toxic or conventional pollutant discharges to surface water bodies. Its major emphasis is on prediction of plume geometry and dilution within an initial mixing zone, but the model also predicts plume behavior at greater distances (Bouchard et al., 1995). The current version allows simulation of submerged or surface, single and multiport discharges. CORMIX has been used by USEPA in rulemaking for produced water discharges.

\subsubsection{Quantification of Exposure}

Exposure defines the contact between the receptors and the contaminant in the environment. Factors considered in estimating exposure include receptor behavior and bioavailability of the contaminant.

\subsubsection{Estimation of Dose}

The calculation of dose or effective concentration is the most common approach to estimating exposure. Estimated environmental concentrations are combined with assumptions or parameters that describe the receptor's contact with environmental media (Suter et al., 1994).

Exposure of aquatic organisms to contaminants in water, and exposure of terrestrial organisms to contaminants in respired air, is usually estimated by assuming that the contaminants are well mixed and that the organism is exposed to a representative concentration. Exposure of terrestrial organisms through ingestion in food, water and soil is estimated by combining ingestion rates with estimates of concentrations in environmental media. USEPA (1993a) tabulated 
parameters needed for an exposure assessment for several birds and mammals. Methods are available to estimate the radiation dose to animals from both external and internal exposure (IAEA, 1979; NCRP, 1991; see section 10).

\subsubsection{Internal Exposure}

\section{Biomarkers and Body Burdens}

Most ecological risk assessments describe exposure in terms of external exposure, or for large terrestrial organisms in terms of intake. In many cases, estimates of internal exposure would be more appropriate. Quantification of internal exposure can be estimated through measurement of biomarkers and body burdens.

Biomarkers measure biochemical or physical changes in an exposed organism. Biomarkers currently have only limited application to ecological risk assessment because of the lack of data relating biomarker measurements to effects (Suter et al., 1994).

The most common approach to estimating internal exposure is through the measurement (or estimation through modeling) of body burdens. This approach works well for exposure to radiation in the environment, because methods are available to estimate dose and related effects (see section 10). For other contaminants the use of body burdens is problematic because there are few data available to relate internal exposure to effects.

Field data, describing concentrations of contaminants in organisms, are usually limited because of the effort and expense involved in sampling biota. A modeling approach is commonly used to estimate the concentration of contaminants in organisms from concentrations in environmental media. The approach used for aquatic organisms is called the bioaccumulation factor approach.

\section{Bioaccumulation Factor}

A bioaccumulation factor (BAF) is useful for estimating tissue concentrations, when the alternative of direct tissue measurements is not available (Lee, 1992). Choice of BAF values are dependent on their biological relevance to potential toxicity. USEPA (1989a) defines a bioconcentration factor (BCF) as the ratio of concentration of a contaminant within an organism to the concentration in water. Practically, BCF is usually based on exposure of an aquatic organism in the laboratory to water containing a contaminant. A BAF is the accumulation of a contaminant in an organism from all sources of exposure, including the ambient medium and trophic considerations. In addition to measurements in the field, 
BAFs are also estimated by calculations that combine BCFs with factors for trophic levels and biomagnification.

BCFs and BAFs are highly uncertain parameters, depending on time of exposure, species, and ambient chemical and physical conditions. Influences on bioaccumulation that are difficult to quantify include intraspecific and interspecies variability, conditioning factors and developmental stages (Franke et al., 1994). Trophic factors add another layer of uncertainty to calculated BAFs.

Although site- and organism-specific factors are desirable, they can be difficult and expensive to obtain. Use of a generic BAF or BCF assumes a steady-state linear relationship between ambient concentrations of a contaminant $\left(\mathrm{C}_{\mathrm{amb}}\right)$ and concentration in an organism $\left(\mathrm{C}_{\text {org }}\right)$, ignoring uncertainty arising from these influences.

$$
B A F=\frac{C_{\text {org }}}{C_{\text {amb }}}
$$

The linear relationship between $C_{\text {org }} / C_{\text {amb }}$ and $B A F$ is usually assumed to be independent of the concentration in the environment. In general, this is valid only for relatively small environmental concentrations. Bioaccumulation factors are often calculated as the geometric mean of a set of bioaccumulation factors in similar organisms that were tested in a specific environment. The BAF approach can produce severe errors if this assumption is not correct. These assumptions, allow the use of generic concentration factors in assessment models. The assumptions may not always be justified, and generic factors can only be used in a preliminary assessment as a first order estimate of bioaccumulation.

In the absence of site-specific BAFs, USEPA recommends that BCF values be obtained in the laboratory, with careful consideration of the problems described above (USEPA, 1989a). A Limited number of BAF values are available for organics, metals and radionuclides (section 8.3 ).

\subsection{Methods and Data for Effects Assessment}

\subsubsection{Toxicity Testing}

By using different methods, periods of exposure, life stages and species; bioassays provide toxicological information on a variety of endpoints for different levels of biological organization. Acute tests usually use mortality as an endpoint, while chronic tests include sublethal endpoints, such as growth, development, reproduction and behavior. When combined with other studies they provide opportunities to determine cause and effect relationships. 
Most standard testing is done in the laboratory, for exposures in water. Standard tests for contaminants associated with sediment have also been developed. Most toxicity studies are performed on individual animals, but there are also methods available to test effects on populations and ecosystems.

\section{Organism Level Tests: Exposure in Water}

Results of toxicity tests on individual animals are usually the basis for the effects assessment. These can be used directly, but more often must be modified to account for differences in response of different species, or to extrapolate to a higher level of organization. Most toxicity tests on individual organisms are performed in the laboratory, although field tests are also possible.

Two types of tests are standard for aquatic organisms: acute and chronic. The standard acute endpoint is the $96-\mathrm{hr}$ or $48-\mathrm{hr}$ median lethal concentration LC 50 (USEPA, 1982; ASTM, 1991). Dose-response functions are derived from the data collected in these toxicity tests, and the $L C_{50}$ value estimated from the function. Models are used both to calculate the single value $L C_{50}$ endpoint and to describe the dynamics of the dose-response function.

Commonly used functions to analyze acute toxicity data are the S-shaped probit and the logit function. These functions assume no threshold and a dichotomous response (i.e. mortality) (Suter, 1993d). Continuous responses and nondichotomous responses can also be fit to these functions by representing the response as a proportion of the control response. For a more detailed description of methods, see Suter (1993d), Stephan (1977), and Kooijman (1983a, 1983b). In the absence of functions relating concentration to response, linear approximations can be constructed by using the origin and the acute toxicity benchmark $\left(\mathrm{LC}_{50}\right)$ to define a line for interpolating the expected response in relation to an exposure concentration (Bartell et al., 1992).

Problems with $\mathrm{LC}_{50}$ tests include the fact that they do not protect early life stages, would allow mass mortality of late stages, and that in most cases only the 96-hour response is reported (Suter, 1993d).

The standard chronic endpoint has been the maximum acceptable toxic concentration (MATC) or "chronic value" which is the threshold for statistically significant effects on survival, growth or reproduction. The MATC is the geometric mean of the lowest concentration producing a statistically significant effect (LOEC, lowest observed effect concentration) and the highest concentration producing no effect on survival, growth or fecundity (NOEC, no observed effect concentration). Because the MATC is derived using hypothesis testing it is not of great value in estimating ecological effects (Suter, 1993c). 
Another standard chronic endpoint is the $\mathrm{EC}_{50}$ (median effective concentration) for effects on growth, reproduction and development. The $\mathrm{EC}_{50}$ is estimated from a dose-response function fit to data from chronic toxicity tests.

Fish Standard tests for fish are acute lethality tests, life cycle tests and early life stage tests. Conditions may be flow-through, static, or static renewal (periodic renewal of test solution). The standard acute endpoint for fish is the 96-hr median lethal concentration LC ${ }_{50}$ (USEPA, 1982; ASTM, 1991). Chronic toxicity tests for fish include full life cycle tests, partial life cycle tests, early life stage tests, and five to eight day chronic tests involving eggs and or larvae. The standard chronic endpoint has been the MATC or "chronic value", and the EC $\mathrm{C}_{50}$ is also in common use.

Aquatic Invertebrates The most common salt water test invertebrates are the shrimp Penaeus duorarum and the mysid crustacean Mysidopsis bahia. These animals are commonly used in 96-hr LC Lo $_{50}$ tests, and 28-d tests of mortality, reproduction and growth. A variety of other aquatic invertebrates are used in 48$\mathrm{h}$ or 96-h lethality tests, including annelids (Neanthes arenaceodentata) (Suter, 1993d).

Mammals Few data are available for assessing the toxic effects of contaminants on mammals. The most common test endpoint available for assessing effects on mammals is the acute, oral, median lethal dose $\left(L D_{50}\right)$ for laboratory rodents (Suter, 1993d). $L_{50}$ s for domestic mice (Mus musculus) and rats (Ratus ratus) are the most common endpoints. No wild animal species is used in routine testing. Testing of birds is based on acute $L D_{50}$ f for adults as well as subacute lethal dietary toxicities for young birds.

\section{Organism Level Tests: Exposure in Sediment}

Sediment toxicity tests directly describe the interactive effects of both measured and unmeasured chemicals in field-collected sediment samples. The tests also account for the influence of biotic and abiotic factors in sediments. Tests are performed on whole sediment, suspended sediment, pore or interstitial water, and sediment extracts (e.g., aqueous and organic solvent). Sediment tests can be performed on field samples to assess the toxicity of chemicals bound to the sediments or in the pore water, or sediment samples can be treated with specific chemicals or chemical mixtures.

Nonvertebrates are the preferred organisms for testing sediments, providing logistical advantages for assaying sediment toxicity. Invertebrate infauna are the preferred eukaryotes because they have the most contact with sediments. Unfortunately, the Gulf of Mexico is one of the geographic regions that are not represented by the species routinely used in sediment toxicity tests. Sets of 
bioassay organisms have been recommended for sediments from aquatic environments of interest (E.V.S. Consultants, 1990):

- Marine waters:

amphipod, Rhepoxynius abronius ;

bivalve larvae;

and Microtox@ (bacterial luminescence)

- Estuarine/brackish waters:

amphipods Hyalella azteca, R. abronius ; and Microtox 8

Amphipods, such as $R$. abronius and $H$. azteca, are readily available sediment dwellers widely used for acute lethal bioassays. Amphipod sensitivity to sediment pollution is well characterized. They have been described as the first organisms to disappear from benthic communities in contaminated sediments (E.V.S. Consultants, 1990; Lamberson, DeWitt and Swartz, 1992). Amphipods are a major food source for bottomfish (Franz and Tanacredi, 1992). Testing with these animals requires a standardized interstitial salinity of $25 \mathrm{ppt} . R$. abronius are unsuitable for sediment samples less than $15 \mathrm{ppt}$ salinity, and salinities from 15 to $24 \mathrm{ppt}$ have to be adjusted to $25 \mathrm{ppt}$. $\mathrm{H}$. azteca, a freshwater amphipod, should be used at salinites of 15 ppt or less. Positive and negative controls are required for toxicants, because of varying sensitivity of life stages and field populations, and sensitivity of the organisms to sedimentsample grain size. Field collected test animals have to be accurately identified by a qualified taxonomist. $H$. azteca has an advantage because it can be cultured.

Bioassays with bivalve larvae are sensitive sublethal 48-hr tests that generally use oysters (Crassostrea gigas) or mussels (Mytilus edulus). The tests measure normal or abnormal development of fertilized ova to free swimming larvae. These bivalves generally do not reside in the types of sediments to be characterized. Therefore the tests are highly sensitive general indicators of toxicity, rather than of ecological significance. Testing is limited by seasonal spawning characteristics of the species, and a lower salinity limit of $10 \mathrm{ppt}$. Positive and negative controls are required for population-specific and seasonal influences on sensitivity to toxicants.

Microtox@ assays measure the degree of inhibition of light emission from the bacterium Photobacterium phosphoreum by aqueous contaminants. It is a measure of the metabolic condition of the organism. This bioassay has been adapted successfully from freshwater testing to marine and estuarine/brackish waters. It is a well-documented, simple, sensitive bioassay, useful for toxicity screening rather than determining ecological significance. This assay depends on extraction procedures, and should be used to test sediments for both water- 
soluble chemicals in aqueous extracts and chemicals extracted by other means. This test can show responses to naturally-occurring chemicals as well as anthropogenic contaminants in sediments, and sediments from areas considered to be uncontaminated can produce positive responses.

\section{Population/Ecosystem Level Tests}

Population and ecosystem level testing are not as well standardized or as widely used as the tests for effects on individual organisms. Two major kinds of tests are in use: microcosms and mesocosms.

Microcosms are laboratory systems that physically simulate an ecosystem or subsystem. Microcosms may be assembled from a standard set of species (assembled microcosms) or created from natural populations removed from the environment (excised microcosms). Standard protocols are available for the standard aquatic microcosm (an assembled microcosm; Federal Register, 1987; ASTM, 1991), and for three excised microcosm tests: mixed flask culture, pond microcosm, and site specific aquatic microcosm (Federal Register, 1987; ASTM, 1991; Suter and Bartell, 1993).

Microcosm endpoints include organism-level parameters, abundance of component organisms, community parameters such as number of species and diversity indices, and parameters that describe ecosystem function (Suter and Bartell, 1993).

Mesocosms are outdoor experimental systems that are to some extent enclosed. Mesocosms are more realistic than microcosms, but are more expensive and less standardized. They may include assembled mesocosms, or delimited portions of natural ecosystems. Assembled mesocosms in use include artificial ponds and streams. Delimited mesocosms include plastic bags and plastic cylinders called lymnocorrals used to enclose portions of a natural ecosystem.

\subsubsection{Effects Extrapolation}

Statistical extrapolation models are used to estimate a toxic effect of interest from a measured effect in another species, life stage or test type. Models have been used to incorporate taxonomic differences, difference in life stage and size, mode of exposure, severity and proportion responding. The following summary is abstracted from Suter (1993d). 


\section{Specific Taxonomic Extrapolations}

Specific taxonomic extrapolations account for the difference between two species, and allow data from one species to predict responses in another. One approach to specific extrapolation is to use the ratio of the responses of two species to other chemicals for which they have both been tested (Schaefer et al., 1983). Regression analysis has also been used to relate the response of one species to that of another (Sloff et al., 1986; Mayer et al., 1987). This approach has limited application because many of the species of interest in an ecological risk assessment are not standard test species.

Suter et al., (1983) and Suter and Rosen (1988) used the taxonomic relationships between test animals and species of interest to estimate the response for species that have not been tested. Regressions were performed between all pairs of species that occur in a common genus, all pairs of genera within a family, families within orders, etc. Extrapolations are made between taxa having the next higher level in common. This approach is based on the assumption that similarity of response is related to taxonomic similarity. Extrapolations between taxa within the same family can be made with fair certainty, but extrapolations between orders, classes or phyla are highly uncertain (Suter, 1993d).

The response of a whole taxon can be predicted on the basis of the response of a test species using regression analysis. Suter et al., (1987) regressed toxicity data for three standard test species (fathead minnow, bluegill, rainbow trout) against all other species that had been tested for a given chemical. $95 \%$ of the time, toxicity for other species fell within $\pm 1.31, \pm 1.37$ and \pm 1.20 of a log unit of the regression line for fathead minnow, bluegill and rainbow trout respectively. Holocombe et al., (1988) used the same technique and found that most species fell within \pm 1 order of magnitude of the regression line.

Extrapolations can also be done on the basis of allometric regression for dose scaling, natural history and guild theory information, and biochemical traits (Suter 1993d).

\section{Generic Taxonomic Extrapolations}

Generic extrapolations use data from one or several species to estimate the sensitivity distribution of the members of the community at risk. The usual approach is to try to identify sensitive species in a community, with the assumption that endpoints for sensitive species will protect the entire community.

In general, it has been found that arthropods are more sensitive than fish, and that fish are more sensitive than amphibian larvae. Salmonids are the most 
sensitive fish. Mysid and peneid shrimp have been found to be the most sensitive marine organisms (Suter and Rosen, 1988). No one species or set of species can be assumed to be consistently the most sensitive.

Observed ranges of species sensitivity can be used as correction factors (Calabrese and Baldwin, 1993). This approach assumes that the relative sensitivity of the test species and the most sensitive species in the community is equal to the most and least sensitive species in the data set (Suter, 1993d).

Another approach is to assume that the sensitivity of species follows some probability distribution, and to define the concentration that affects the most sensitive species as the lower $X$ th percentile (e.g. lower 5 th percentile; Suter, 1993d).

\section{Acute to Chronic Extrapolations}

In aquatic toxicology, the terms acute and chronic are used to describe both the severity of the effect, and the duration of the exposure; confounding the need to estimate low severity, chronic effects from severe effects. Acute exposures are assumed to be both of shorter duration and result in a more severe effect (mortality) than do chronic exposures.

Many more acute than chronic toxicity tests have been performed for aquatic animals, and chronic endpoints have been estimated from the results of acute toxicity tests.

One approach is the use of an application factor (AF) which is the ratio of the chronic threshold concentration to the acute $L C_{50}$. USEPA uses the acute to chronic ratio in deriving water quality criteria (USEPA, 1986). Application factors can be derived across all species and chemicals or can be derived for specific chemicals (Suter 1993d).

Another approach is to regress chronic threshold values against acute $L_{50}$ values. This approach is useful for some chemicals because the AF decreases with an increase in the $L_{50}$. Suter et al., $(1983,1986)$ derived acute/chronic equations for fish.

\subsection{Methods for Risk Characterization}

Approaches to risk characterization in ecological assessment were reviewed by Suter (1993b) and Wiegart and Bartell (1994). Major approaches to risk characterization include comparing effects and exposure data (single values or distributions) and the use of mechanistic models to estimate effects on populations and ecosystems. 


\subsubsection{Compare Exposure and Effects Values}

\section{Quotient Method}

A common approach to ecological risk characterization is the quotient method (USEPA, 1992; Suter 1993c; Calabrese and Baldwin, 1995). The quotient method is a ratio of an exposure concentration to an effect value. Uncertainty or safety factors are used to adjust the effect value. If the quotient is one or more, an adverse effect is considered likely to occur. Quotients are most useful for screening purposes (Wiegart and Bartell, 1994).

\section{Comparing Distributions}

This approach compares distributions of exposures and effects. Risk is quantified by the degree of overlap between the two distributions. The use of distributions recognizes the variability in exposure in space and time and the natural variability in response of individuals and populations. Approaches to risk characterization based on comparison of distributions of exposure and response are described in detail in Suter (1993c).

\subsubsection{Population and Ecosystem Level Effects}

Barnthouse (1993) and Suter and Bartell (1993) reviewed methods and models for assessing population and ecosystem effects. These reviews are summarized here. Few example applications of these approaches are available in the literature.

\section{Population Models and Approaches}

Models for assessing risk to wildlife should address endpoints of regulatory relevance, easily incorporate toxicological information, use available population data, and be linkable to models of chemical exposure (Emlen, 1989). Potential endpoints at the population level include alteration of mean population densities or biomass, alteration of the age or size distribution of the population, and probability of extinction.

Approaches to assessment of risks at the population level should consider the potential influence of life history and density dependence on sensitivity to stress from exposure to toxicants.

In general, long-lived vertebrates such as large mammals and predatory birds are more sensitive to mortality imposed on adults than are short-lived, highly fecund species (Barnthouse, 1993). Short-lived species are often more vulnerable to short-term stresses that affect critical life stages. Most populations exhibit some form of density dependence (Barnthouse, 1993): when population 
numbers are high, mortality increases and reproduction decreases; and when numbers are low, mortality decreases and reproduction increases. Populations in which survival or reproduction is strongly related to density should be less vulnerable to stress from exposure to toxicants (or exploitation from man) than populations with a low degree of population dependence.

Two major approaches to population analysis are used in models for ecological risk assessment: quantification of reproductive potential, and age-structure projection matrices. These approaches are summarized by Barnthouse (1993).

Toxicity tests can be linked to population models to estimate population-level effects. One approach uses the reproductive potential index to quantify the effect of exposure to a toxicant on changes in mortality and reproduction. Another approach uses matrix-type life cycle models to estimate changes in yield, abundance and risk of extinction.

Barnthouse et al. $(1987,1989,1990)$ linked toxicity data to fish population models. Two different approaches to population modeling were used. The first used standard survival and reproduction data to calculate an index of reproductive potential (Barnthouse et al., 1987). These indices are used as relative measures of impact, expressed as a fractional reduction in reproductive potential (Barnthouse, 1993).

This approach does not account for natural environmental variability or density dependence. Barnthouse et al. (1990) developed density dependent stochastic matrix models of two well studied populations: the Gulf of Mexico menhaden population and the Chesapeake Bay striped bass population.

Barnthouse et al. (1990) quantified population level effects of chronic exposure by coupling standard toxicity tests data to matrix type population models for the Gulf of Mexico menhaden and Chesapeake Bay striped bass populations.

\section{Ecosystem Models}

Ecosystem models attempt to represent mathematically the ecological processes and structure of an ecosystem, and can be used to predict adverse ecological effects in ecosystems. Some existing models were developed to assess the ecological effects of toxic materials, while others were designed as basic research tools. Suter and Bartell (1993) summarized existing aquatic ecosystem models that might be used in ecological risk analysis.

Aquatic ecosystem models of particular interest here include the SWACOM (Standard Water Column Model; O'Neil et al., 1982; O'Neil et al., 1983; Bartell et al., 1988a) and the Integrated Fate and Effects Model (IFEM; O'Neil et al., 1982; Bartell et al. (1988b) . 
The SWACOM model (O'Neil et al., 1982; O'Neil et al., 1983; Bartell et al., 1988a, Bartell et al., 1992) was developed to extrapolate the results of acute toxicity bioassays to probabilistic estimates of specific toxic effects in aquatic systems. The model describes the temporal biomass production of 10 populations of phytoplankton, 5 populations of herbivorous zooplankton, 3 populations of planktivorous fish and a single population of piscivorous fish. Each population is defined by parameters that determine rates of photosynthesis, respiration, feeding, mortality and optimal conditions for growth. The model uses difference equations to simulate daily changes in biomass concentrations. Toxicity data for species representative of the food web populations and an estimated (time invariant) exposure are needed. This model permits an evaluation of the potential higher-order effects of toxic chemicals on system structure and function.

The IFEM model (O'Neil et al., 1982; Bartell et al. 1988b) integrates the physiological processes associated with chemical kinetics, with dynamic estimates of chemical fate. The code currently models PAH's only. The model requires toxicity data and kinetic information, and estimates population-specific toxic effects as a function of body burden. The food web consists of single populations of algae, periphyton, macrophytes, bacteria, zooplankton, benthic insects, larger benthic invertebrates, and detritivorous and omnivorous fishes. The model predicts the time varying concentration of toxicant in each model component and the time varying change in population size that results from sublethal effects.

\subsection{Uncertainty}

The current application of the National Research Council risk assessment paradigm (NRC, 1983) to the estimation of risk to the natural environment requires explicit description of uncertainties in assumptions, models and parameters and incorporation of these uncertainties in a final expression of risk. Until recently, the common practice in risk assessment was to use conservative assumptions in a "worst case" analysis rather than to estimate uncertainty. This approach obscures recognition of the degree of conservatism and the uncertainties in risk estimates, allows for improbable scenarios and results, and ignores the potential costs of decisions made based on conservative assumptions (Burmaster et al., 1990; Paustenbach et al., 1991).

A common way to describe uncertainties in risk assessment is to recognize three fundamental sources of uncertainty: the heterogeneity or stochasticity of natural systems, measurement error, and lack of knowledge. Other approaches to describing uncertainty have also been suggested (Smith and Shugart, 1994). 
Uncertainties in ecological risk assessments that come from a basic lack of knowledge should be described qualitatively. Other major uncertainties, including natural heterogeneity or stochasticity, and parameter error can be treated analytically. Statistical methods can be used to derive the variance on a parameter estimate by fitting models to data (Suter, 1993c; Suter and Rosen, 1988).

A commonly used tool in risk assessment is Monte Carlo analysis. In a Monte Carlo analysis, a sample from the distribution of an input parameter is placed into a simulation run to interact in a model with samples from other input parameters. The frequency of sampling within an independent variable depends on the relative frequency of a value in the frequency distribution (Paustenbach et al., 1991).

Uncertainties occur in all phases and steps of an ecological risk assessment. Table 2-1 (from Smith and Shugart, 1994) summarizes some of the uncertainties in ecological risk assessment and their potential influence.

\subsection{Data for Ecological Risk Assessments in the Gulf of Mexico}

Much of the basic data and information needed in an ecological risk assessment for produced water discharges in the Gulf of Mexico are summarized in the following sections. Each of the sections describe data or information relevant to the phases of an ecological risk assessment as described above.

Sections 3, 4 and 5 describe important biological resources in the Gulf of Mexico to support the problem formulation phase and guide the identification of assessment endpoints.

Data describing produced water characteristics, including chemical concentrations and discharge rates are provided in section 6 to support the development of source terms and exposure assessments. Bioaccumulation data are also summarized to support exposure assessments (section 8 ).

Data describing the toxicity of produced water and component chemicals are reviewed to support effects assessments (sections $7,9,10$ ). Documented biological effects from produced waters are largely limited to impacts on benthic invertebrate communities, and these are summarized to support effects assessments at the community level (Section 11). 
Table 2-1. Uncertainties and their importance in ecological risk assessment (from Smith and Shugart, 1994; adapted from Cothern, 1988).

\begin{tabular}{|c|c|c|}
\hline Source of Uncertainty & Importance & Magnitude of Effect \\
\hline Poor knowledge of System & $\begin{array}{l}\text { Without any knowledge of the } \\
\text { system, it is not possible to } \\
\text { build a useful model. }\end{array}$ & Many orders of magnitude \\
\hline $\begin{array}{l}\text { Extreme variation, incorrect } \\
\text { scales }\end{array}$ & $\begin{array}{l}\text { Great variation in weather, for } \\
\text { example, may cause a large } \\
\text { change in the importance of } \\
\text { the stressor. Modeling large- } \\
\text { scale phenomenon using a } \\
\text { small-scale model may lead to } \\
\text { great uncertainty. }\end{array}$ & \\
\hline $\begin{array}{l}\text { Wrong model, endpoints, } \\
\text { exposure routes }\end{array}$ & $\begin{array}{l}\text { Measuring the wrong endpoint } \\
\text { may lead to missed effects. } \\
\text { Lack of knowledge of the } \\
\text { exposure or model may lead } \\
\text { to large errors. }\end{array}$ & \\
\hline Surprises & $\begin{array}{l}\text { Unexpected effects may occur } \\
\text { caused either by important } \\
\text { gaps in knowledge or by } \\
\text { random effects. Despite low } \\
\text { probability of occurrence, } \\
\text { effects can have great } \\
\text { consequence. }\end{array}$ & \\
\hline Data collection practices & $\begin{array}{l}\text { Errors in data collection and } \\
\text { entry may lead to mistakes in } \\
\text { interpreting statistical } \\
\text { analyses. }\end{array}$ & Order(s) of magnitude \\
\hline $\begin{array}{l}\text { Design of laboratory } \\
\text { experiments and quality } \\
\text { control }\end{array}$ & $\begin{array}{l}\text { Adherence to laboratory } \\
\text { standards is necessary to } \\
\text { avoid errors induced by lack } \\
\text { of care. }\end{array}$ & \\
\hline $\begin{array}{l}\text { Variability in mesocosms or } \\
\text { other ecosystem surrogates }\end{array}$ & $\begin{array}{l}\text { Mesocosm studies have } \\
\text { higher variability than } \\
\text { laboratory studies and need to } \\
\text { be carefully designed. }\end{array}$ & \\
\hline Extraneous variables & $\begin{array}{l}\text { Physical conditions may have } \\
\text { a strong effect on laboratory } \\
\text { results. }\end{array}$ & \\
\hline Mistakes in statistical analysis & $\begin{array}{l}\text { Outliers, wrong statistical } \\
\text { model. }\end{array}$ & \\
\hline
\end{tabular}


Table 2-1. (cont.)

\begin{tabular}{|c|c|c|}
\hline Source of Uncertainty & Importance & Magnitude of Effect \\
\hline Interactions & $\begin{array}{l}\text { Uncertainty may be introduced } \\
\text { by failing to account for } \\
\text { interactions among species or } \\
\text { combined effects of chemicals } \\
\text { or other stressors. }\end{array}$ & \\
\hline $\begin{array}{l}\text { Parameterization of Computer } \\
\text { Model }\end{array}$ & $\begin{array}{l}\text { Parameter estimates are } \\
\text { taken from the literature, not } \\
\text { from a fit to actual } \\
\text { observations. }\end{array}$ & \\
\hline $\begin{array}{l}\text { Mistakes in computer code of } \\
\text { simulation model }\end{array}$ & $\begin{array}{l}\text { Errors in code may lead to } \\
\text { gross prediction errors. }\end{array}$ & \\
\hline $\begin{array}{l}\text { Extrapolations across one } \\
\text { species to another species in } \\
\text { community or from laboratory } \\
\text { to field spatial scale (local to } \\
\text { regional) }\end{array}$ & $\begin{array}{l}\text { Using a model developed for } \\
\text { a simple endpoint may lead to } \\
\text { errors when applied to } \\
\text { estimate a more complex } \\
\text { endpoint. }\end{array}$ & \\
\hline $\begin{array}{l}\text { Variability in laboratory test } \\
\text { conditions }\end{array}$ & $\begin{array}{l}\text { Variation in test organisms or } \\
\text { concentrations of chemicals, } \\
\text { for example, may cause } \\
\text { under- or over-estimation of } \\
\text { effects. }\end{array}$ & Up to one order of magnitude \\
\hline $\begin{array}{l}\text { Minor mistakes in choice of } \\
\text { statistical model }\end{array}$ & $\begin{array}{l}\text { Including variables that are } \\
\text { not necessary in the model } \\
\text { may lead to increased } \\
\text { variance; missing variables } \\
\text { may add a bias. }\end{array}$ & \\
\hline $\begin{array}{l}\text { Statistical design of } \\
\text { manipulative studies (choice } \\
\text { of stressor levels, } \\
\text { randomization, number of } \\
\text { experimental units, number of } \\
\text { units per treatment) }\end{array}$ & $\begin{array}{l}\text { Proper statistical design is } \\
\text { important in laboratory and } \\
\text { field studies especially when } \\
\text { sample sizes are limiting. } \\
\text { Estimates of quantities, such } \\
\text { as No Observed Effect Levels, } \\
\text { may be greatly affected by } \\
\text { sample size and other factors. }\end{array}$ & Potentially of great importance \\
\hline Design of field study & $\begin{array}{l}\text { Haphazard design of field } \\
\text { studies may lead to incorrect } \\
\text { decisions regarding effects. }\end{array}$ & \\
\hline
\end{tabular}




\section{BIOLOGICAL RESOURCES IN THE GULF OF MEXICO}

\subsection{Major Ecosystems}

The Gulf of Mexico includes a wide variety of habitats for marine biota, both in the water column and on the seafloor. Darnell and Phillips (1988) describe the major ecosystems of the Texas-Louisiana Continental shelf and the upper continental slope. Three basic systems with transitional systems in between are recognized: the water column, soft bottom benthos, and hard substrate structurerelated systems (Table 3-1).

Important coastal ecosystems associated with the Gulf of Mexico include extensive wetlands and estuaries. Wetlands along the Gulf Coast include fresh, brackish and saline marshes, forested wetlands and small areas of mangroves. Coastal wetlands are characterized by high organic productivity, high detritus production, and efficient nutrient recycling (MMS, 1993). Wetlands provide habitat for a great number and diversity of invertebrates, fish, reptiles, birds and mammals, and are important nursery grounds for many species of fish.

Table 3-1. Major ecological systems of the Texas-Louisiana continental shelf and upper continental slope (modified from Darnell and Phillips, 1988).

\begin{tabular}{|c|c|c|}
\hline Major Systems & Subsystems & Components \\
\hline Water Column & $\begin{array}{l}\text { Coastal waters } \\
\text { Oceanic waters }\end{array}$ & $\begin{array}{l}\text { Phytoplankton } \\
\text { Zooplankton } \\
\text { Neuston } \\
\text { Nekton }\end{array}$ \\
\hline $\begin{array}{l}\text { Soft-bottom } \\
\text { Benthic }\end{array}$ & $\begin{array}{l}\text { Continental shelf } \\
\text { Upper continental slope }\end{array}$ & $\begin{array}{l}\text { Meiofauna } \\
\text { Macrofauna } \\
\text { Megafauna } \\
\text { Demersal fauna }\end{array}$ \\
\hline $\begin{array}{l}\text { Hard substrate, } \\
\text { structure-related }\end{array}$ & $\begin{array}{l}\text { Natural substrates } \\
\text { Artificial substrates }\end{array}$ & $\begin{array}{l}\text { Hard bank biota } \\
\text { Biofouling mat } \\
\text { Niche fauna } \\
\text { Structure-associated } \\
\text { fauna }\end{array}$ \\
\hline Transitional & $\begin{array}{l}\text { Combinations of the } \\
\text { above }\end{array}$ & $\begin{array}{l}\text { Mixtures and } \\
\text { combinations } \\
\text { of the above }\end{array}$ \\
\hline
\end{tabular}




\subsection{Biota}

The larger, free swimming animals (nekton) of the Gulf of Mexico include squid, fish, sea turtles and cetaceans. Both coastal and pelagic assemblages are recognized (Darnell and Phillips, 1988). Table A-1 in Appendix A lists common nektonic species in the Northern Gulf of Mexico. The following summary is abstracted from MMS (1993) and Darnell and Schmidly (1988).

Coastal pelagic species such as mackerels, cobia, bluefish, amberjack and dolphin move seasonally within the Gulf of Mexico (MMS, 1993). King and Spanish mackerel winter in the southeastern Gulf, and spawn and summer in the Northeastern Gulf along the continental shelf.

Oceanic species including yellowfin and bluefin tuna are found mainly beyond the continental shelf during winter and spring, and move into the Atlantic Ocean after spawning. Black marlin, white marlin, sailfish and swordfish spawn in the northeastern Gulf, mostly beyond the continental shelf.

The demersal fauna are those associated with near bottom waters and include shrimp, crabs, and fishes. Tables A-2 and A-3 in Appendix A list demersal species common along the continental shelf and upper continental slope in the northern Gulf of Mexico.

In the continental shelf areas, populations from the inshore shelf zone $(7-14 \mathrm{~m})$ are dominated seasonally by Atlantic croaker, spot, drum, silver seatrout, southern kingfish and Atlantic threadfin. The middle shelf zone $(27-46 \mathrm{~m})$ is dominated by longspine porgies and sciaenids. In the outer shelf zone (64$110 \mathrm{~m}$ ) blackfin searobin, Mexican searobin and shoal flounder are dominant.

As many as 15 species of shrimp are found in the coastal and estuarine areas of the Gulf of Mexico. Brown, white and pink shrimp are the most common. About eight species of portunid crab are found along the Gulf Coast. The blue crab is the only species that represents a substantial fishery.

Natural reefs and banks support large numbers of grouper, snapper, gag, scamp and seabass. Reef fish occur wherever hard bottoms with rocks or crevices are available, and are also associated with platforms. Snappers are estuary independent fish that remain close to underwater features or structures.

Many of the fishes in the Gulf of Mexico are estuary dependent. Estuarydependent species spawn on the continental shelf, move into the estuaries as eggs, larvae or juveniles, grow and mature in the estuary, and migrate back to the shelf to spawn. Important estuary-dependent species include menhaden, 
shrimps, crabs, oysters and sciaenids (croaker, red drum, black drum, spotted seatrout).

Benthic Fauna include the infauna (animals that live in the substrate) and epifauna (animals that live on or are attached to the substrate). The most important factor in the distribution of benthic fauna is the type of substrate (MMS, 1993). The vast majority of the Northern Gulf of Mexico consists of soft, muddy bottoms dominated by polychaetes.

Benthic biota may be classified in terms of size (Darnell and Schmidly, 1988):

- microbenthos $<0.062 \mathrm{~mm}$

- meiobenthos $0.062-1.0 \mathrm{~mm}$

- macrobenthos 1.0-25.4 mm

- megabenthos $>25.4 \mathrm{~mm}$

The microbenthos includes primarily bacteria, protozoa, fungi and blue-green algae. The meiobenthos includes nematodes, kinorhynchs, polychaetes, and harpacticoid copepods. Macrobenthos recorded in the Gulf of Mexico include well over a thousand species (see Table A-4 in Appendix A), and are dominated by polychaetes, crustaceans, and mollusks. The megabenthos includes bivalves, gastropods, and crustaceans. Depth related faunal assemblages have been identified by Defenbaugh (1976), see Table A-5 in Appendix A.

Estuaries in the Gulf of Mexico are often characterized by intertidal reefs constructed by oysters. When submerged, these reefs provide habitat and food for finfishes, crabs, and shrimp.

The communities associated with hard bottom substrate, reefs and banks, and platform structures are very different from soft bottom communities. Hard-bottom communities may include barnacles, oysters, hermatypic (reef-building) and ahermatypic (non-reef building) corals, and reef fish. Demersal and pelagic species with various levels of association to the structures are also found nearby. The communities associated with artificial platform structures are described in more detail in section 4. The biota associated with topographic highs identified as unique and sensitive ecosystems are described in section 5 .

\subsection{Commercial and Recreational Fisheries}

The commercial fishery resources of Texas and Louisiana are of national importance, and the Gulf of Mexico provides almost 20 percent of commercial fish landings in the United States (MMS, 1993). The most important species in terms of quantity in 1991 was menhaden (1.2 billion pounds, $\$ 41$ million; USDOC, 1992). Shrimp harvest was the most important in terms of value (229 million pounds, $\$ 411$ million; USDOC, 1992). In 1991, the oyster fishery in the 
Gulf of Mexico accounted for 43 percent of the national total ( 13.7 million pounds meats, $\$ 35.5$ million) and 29 percent of the national total for the blue crab fishery (65.4 million pounds, $\$ 23.5$ million).

In Louisiana, menhaden was the most important species in terms of quantity (1.0 billion pounds, $\$ 48$ million), and shrimp was the highest value shellfish (27.3 million pounds, $\$ 36.7$ million). In 1991, the following nine species accounted for landings valued at over $\$ 1$ million: black drum, red mullet roe, shark, snapper, spotted sea trout, bluefin tuna, yellowfin tuna, blue crab, and American oyster (USDOC 1992; MMS, 1993).

In Texas in 1991, shrimp ranked first in both quantity and value (92 million pounds, $\$ 17$ million). During 1991, the following species accounted for landings values over $\$ 500,000$ : red snapper, black drum, blue crab and American oyster (USDOC, 1992; MMS, 1993).

Many of the commercially important fish species in the Gulf of Mexico are believed to be in decline due to overfishing (USDOC, 1992). Fisheries in danger of collapse include shrimp, red snapper, black drum, shark, tuna, and spiny lobster. Fisheries Management Plans have been implemented to assess and manage commercial species in need of conservation. Fisheries Management Plans have been implemented for the following Gulf species: shrimp, stone crab, spiny lobster, coastal pelagics (king and Spanish mackerel), coral, reef fish (red snapper), swordfish, red drum, sharks, snapper and grouper.

Marine recreational fishing in the Gulf of Mexico accounts for an estimated $\$ 769$ million in sales and employment for over 15,000 people (Sports Fishing Institute, 1987 as cited in MMS, 1993). Approximately $43 \%$ of the fish taken by recreational fishermen in the United States in 1991 were from the Gulf of Mexico (excludes Texas; data from tables in USDOC, 1992). Recreational fishing takes place from shore or within state waters, as well as offshore from private or charter boats.

In nearshore waters, recreational fishing is aimed at estuary-dependent species, particularly members of the drum family (sand and spotted seatrout, croakers, red drum).

Sportfishing in Louisiana and Texas is concentrated around oil and gas structures. In 1984, approximately $37 \%$ of all saltwater fishing trips in Louisiana and $28 \%$ in Texas were within 200 feet of an oil or gas structure. It has been estimated that over $70 \%$ of the fishing trips beyond three miles from shore are to areas near oil and gas structures (Witzig, 1986; Reggio, 1987). In the Gulf of Mexico, Ditton and Auyong (1984) found heavy use of offshore platforms by private recreational fishing boats. Most private recreational boats were bottom fishing, with snapper and seatrout reported most frequently as the major target 
species. Croaker was reported as a major target species in the Delta Region. The catch near oil and gas platforms was primarily $(80 \%$, excluding saltwater catfish) red snapper, sand seatrout, and Atlantic croaker (Witzig, 1986). On nonrig fishing trips, round scad, grunts and snappers made up over $70 \%$ of the catch (Witzig, 1986).

Stanley and Wilson (1990) surveyed recreational fishermen and charter boat operators in Louisiana in 1987 and 1988, and found the most common fishing method was offshore bottom fishing at oil and gas structures. The five most frequently caught species (or groups of species) in the 1987 survey were red snapper, spotted seatrout, silver/sand seatrout, other snapper and greater amberjack. The most frequently caught species in 1988 were red snapper, spotted seatrout, other snapper, silver/sand seatrout and gray triggerfish. The major target species for offshore bottom fishing was red snapper, and nearshore fishing near platforms targeted spotted seatrout. Stanley and Wilson also documented catch rates for offshore trolling near platform structures. They found that the catch was not dominated by any one species but included blue runner, dolphin, king mackerel, little tunny and Spanish mackerel. Table 3-2 summarizes the composition of the catch for the survey participants.

Recreational fishermen also take pelagic species not associated with platform structures including tarpons, cobias, dolphins, amberjacks and other jacks, little tunnys and billfishes (Linton, 1988).

\subsection{Application to Ecological Risk Assessment for Produced Water Discharges}

A description of the important fisheries resources in the Gulf of Mexico is needed to complete the problem formulation phase of an ecological risk assessment and to identify appropriate endpoints for a specific analysis. More site or region specific data may be needed for a specific analysis, and species with important social value other than commercial or recreational should also be considered (section 5). 
Table 3-2. Composition of catch around oil and gas platforms off Louisiana (modified from Stanley and Wilson, 1990).

\begin{tabular}{|l|l|l||l|l|l|}
\hline Species/group & 1987 & 1988 & Species/group & 1987 & 1988 \\
\hline & $\%$ & $\%$ & & $\%$ & $\%$ \\
\hline Atlantic croaker & 2.0 & 0.5 & Little tunny & 0.8 & 1.0 \\
\hline Atlantic spadefish & 0.1 & 0.7 & Lookdown & 0.0 & 0.2 \\
\hline Bearded brotula & 0.0 & 0.0 & Other jacks & 0.1 & 0.1 \\
\hline Black drum & 0.4 & 0.5 & Other snapper & 4.7 & 8.1 \\
\hline Blackfin tuna & 0.1 & 0.1 & Pinfish & 0.3 & 0.4 \\
\hline Bluefish & 2.8 & 1.8 & Puffer & 0.0 & - \\
\hline Blue martin & 0.0 & 0.0 & Rainbow runner & 0.0 & 0.0 \\
\hline Blue runner & 0.6 & 1.5 & Rays & 0.0 & 0.0 \\
\hline Cobia & 1.1 & 1.1 & Red drum & 2.9 & 1.1 \\
\hline Crevalle Jack & 0.1 & 0.2 & Red snapper & 34.6 & 41.2 \\
\hline Cubbyu & 0.0 & - & Sharks & 1.5 & 1.2 \\
\hline Dolphin & 0.9 & 3.7 & Sheepshead & 0.1 & 0.1 \\
\hline Florida pompano & 0.7 & 0.1 & Shrimp eel & 0.0 & 0.1 \\
\hline Flounder & 0.0 & 0.1 & Silver/sand seatrout & 8.2 & 5.8 \\
\hline Gafftopsail catfish & 0.2 & 0.3 & Skipjack tuna & 1.4 & 1.5 \\
\hline Great barracuda & 0.2 & 0.1 & Spanish mackerel & 1.7 & 1.3 \\
\hline Greater amberjack & 4.1 & 4.3 & Spotted seatrout & 21.8 & 9.4 \\
\hline Grey triggerfish & 2.7 & 5.9 & Squirrelfish & 0.0 & 0.1 \\
\hline Grouper & 2.7 & 4.7 & Tarpon & 0.0 & 0.0 \\
\hline Grunts & 0.2 & 0.8 & Tripletail & 0.2 & 0.0 \\
\hline Hake & 0.0 & 0.0 & Wahoo & 0.1 & 0.2 \\
\hline Hardhead catfish & 1.1 & 0.3 & White spotted soapfish & 0.0 & - \\
\hline King mackerel & 1.2 & 1.2 & Yellowfin tuna & 0.0 & 0.0 \\
\hline Ladyfish & 0.1 & 0.0 & & & \\
\hline
\end{tabular}




\section{PLATFORM COMMUNITIES}

\subsection{Introduction}

Oil and gas platform structures are colonized by microorganisms, algae, and sessile invertebrates that live attached to the structure and form the biofouling mat. These organisms provide food and habitat for many motile invertebrates and small fishes that live in close association with the biofouling mat. There is also a diverse assemblage of demersal and pelagic fishes associated with the platforms, some of which are residents. The composition of the biofouling community and assemblage of demersal and pelagic fishes associated with platforms varies with distance from shore, water depth, latitude and age of the platform (Gallaway and Lewbel, 1982). Gallaway and Lewbel (1982) and Darnell and Schmidly (1988) summarized the results of several studies of platform communities (Gallaway et al., 1981a, b; Gallaway 1981; Bert and Humm, 1979; Fotheringham 1981; George and Thomas, 1979; Middleditch, 1981). The following summary is from Gallaway and Lewbel (1982) and Darnell and Schmidly (1988).

\subsection{Biota Associated With Platform Structures}

\section{Biofouling Community}

Gallaway and Lewbel (1982) described three faunal groups at platforms in the Northwestern Gulf of Mexico: coastal (below 30 meters depth); offshore (30-60 meters depth); and bluewater (greater than 60 meters depth). The biomass of the biofouling mat generally ranges from about $1-5 \mathrm{~kg} / \mathrm{m}^{2}$ (oceanic waters) to 15 $\mathrm{kg} / \mathrm{m}^{2}$ (nearshore surface waters) (Darnell and Schmidly, 1988).

A large number of algal species are associated with platforms, but most are small or microscopic. The greatest portion of the algae growth is close to the surface. Brown and red algae become more abundant in oceanic waters.

Sponges form a large proportion of the mat of fouling organisms, covering the shells of barnacles and bivalves on the platforms. Sponges are relatively unimportant on bluewater platforms.

On coastal platforms in Louisiana, the dominant biofouling organisms are the stalked barnacles (Balanus amphitrite niveus $=B$. reticulatus) and $B$. improvisus. On coastal platforms in Texas, B. tintinnabulum is dominant. Barnacles are relatively unimportant components of the biofouling community at offshore platforms. On bluewater platforms, stalked barnacles are the primary biofoulers (Darnell and Schmidly, 1988). 
At least four species of oysters are found on Gulf of Mexico platforms: Crassostrea virginica, Ostrea equestris, Isognomon bicolor and Hyotissa thomasi. Platforms in Louisiana do not support large numbers of bivalves at shallow depths, but deeper portions of platforms may support large numbers of oysters. Oysters and other bivalves are common on coastal platforms in Texas waters. On offshore platforms in Louisiana, bivalves replace barnacles as the dominant biomass. Important species include tree oysters (Isognomon bicolor) and leafy jewel boxes (Chama macerophylla).

Hydroids are patchy but can be extremely abundant on offshore and coastal platforms in both Louisiana and Texas. Hydroids are the dominant species in many near-bottom samples, but are often the most abundant (on a weight basis) near the surface.

Anemones are important components of the biofouling community, especially on coastal platforms in both Texas and Louisiana. They tend to form distinct zones at specific depths, especially toward the bottom.

Bryozoans are patchy in time and space on coastal and offshore platforms in Louisiana, but may be extremely abundant. Bryozoans are common on Texas coastal platforms, but tend to die back in winter months.

Stony corals and octocorals have been found at platforms, but are numerically unimportant. Identified Octocoral species include Telesto sp., a low-profile encrusting species, and Leptogorgia virgulata (gorgonian sea whip). Several species of small ahermatypic (non reef-building) corals have been found at platforms, including Astrangia sp., Phyllangia americana, and Oculina diffusa.

Table 4-1 summarizes the dominant organisms for coastal, offshore and blue water biofouling communities. A partial list of the invertebrates and algae associated with platform structures in the Gulf of Mexico, including species that comprise the biofouling community, is given in Appendix A (Table A-6). 
Table 4.1. Dominant organisms (by weight) for coastal, offshore and blue water biofouling communities (modified from Darnell and Schmidly, 1988).

\begin{tabular}{lll}
\hline Assemblage & \multicolumn{2}{c}{ Dominant Organisms } \\
\hline Coastal & $\begin{array}{l}\text { Reticulated barnacle } \\
\text { Bay barnacle } \\
\text { Mediterranean barnacle } \\
\text { Virginia oyster } \\
\text { Horse oyster }\end{array}$ & $\begin{array}{l}\text { Balanus reticulatus } \\
\text { Balanus improvisus } \\
\text { Megabalanus antillensis } \\
\text { Crassostrea virginica } \\
\text { Ostrea equestris }\end{array}$ \\
Transitional (Offshore) & $\begin{array}{l}\text { Leafy jewel box } \\
\text { Tree oyster }\end{array}$ & $\begin{array}{l}\text { Chama macerophylla } \\
\text { Isognomon bicolor }\end{array}$ \\
Blue water & $\begin{array}{l}\text { Striped goose barnacle } \\
\text { Common goose barnacle }\end{array}$ & $\begin{array}{l}\text { Conchoderm virgatum } \\
\text { Lepas anatifera }\end{array}$ \\
\hline
\end{tabular}

\section{Non-Attached Species Living in Close Association With the Biofouling Community}

Species that live in close association with the biofouling community include a variety of worms, crustaceans, echinoderms and other small invertebrates and blenny fish. General conclusions about the motile epifaunal invertebrates on platforms in the Northwestern Gulf of Mexico were made by Gallaway and Lewbel (1982):

"1. An extremely diverse assemblage of small and large motile invertebrates utilize the shelter and food provided by sessile members of the community.

2. The most abundant amphipods are tube-dwelling forms such as corophiids, stenothoids, and caprellids which are typically symbiotic with hydroids and other mat organisms.

3. The most commonly reported polychaetes are syllids, a group often associated with hydroids and sponges.

4. Pycnogonids, another epibiotic group, are frequently found on the fouling mat.

5. Nermerteans are common predators on the other epifaunal invertebrates on the platforms. 
6. Ophiuroids may be present in very high densities embedded in the fouling mat.

7. Large, conspicuous invertebrates such as lobsters and crabs may be found in low densities around and beneath platforms".

Small fishes, particularly blennies, may reside in old barnacle shells and other niches in the biofouling mat (Darnell and Schmidly, 1988). A partial list of the invertebrates and algae associated with platform structures in the Gulf of Mexico, including non-attached species, is given in Appendix A (Table A-6).

\section{Large Mobile Species}

Larger mobile species that have a relatively loose association with the platform structure include shrimp, larger crabs and lobsters, fishes, and sea turtles. Common crustaceans on platforms include pistol shrimp (Synalpheus spp.), arrow crabs (Stenorhynchus seticornis), Xanthid crabs (Xanthidae) and in deeper water spiny lobster (Panulirus argus) (Gallaway and Lewbel, 1982). A large number of fish species have been reported around platforms in the Gulf of Mexico (Appendix A, Table A-7).

Some of the resident fish species are trophically dependent on the biofouling mat (e.g., sheepshead, gray triggerfish, butterflyfishes). Other residents, including spadefish, red snappers and groupers are mainly trophically independent of the biofouling mat and are attracted by the structure itself for cover.

The barracuda (Sphyraena barracuda), almaco jack (Seriloa rivoliana) hammerhead sharks (Sphryna spp.), cobia (Rachycentron canadum) and bluefish (Pomatomus saltatrix) are predator species that feed upon other resident platform species and may have a longer residence time than do the other large predators (Gallaway and Lewbel, 1982). Large predatory species believed to be highly transient include mackerels (Scombridae), jacks (Caranx spp.) and the little tunny (Euthynnus alletteratus). These species come and go to platforms for periods of hours to days as they follow schools of prey fish such as scads and sardines. Except for bluefish, large predators that feed upon the platform residents are not numerous. Around a given structure bluefish are usually present in schools of up to about 5,000 individuals (Gallaway and Lewbel, 1982). For food, bluefish may depend on pelagic prey species, surrounding soft bottom fish, and crustacean populations as well as platform residents. 


\section{Coastal Platforms}

Gallaway and Lewbel (1982) summarized the vertical zonation of the assemblage of fishes at coastal Louisiana platforms. "According to Shinn (1974), the vertical zonation of fishes around Louisiana coastal platforms is characterized by spadefish, barracuda, lookdown and sheepshead in the upper part of the water column, red snapper and large groupers typically near the bottom, but often in mid-water, and on the bottom, species such as speckled trout (Cynoscion nebulosus), sand trout (Cynoscion arenarius) and flounders (Paralichthys sp.). To the bottom group we would add the Atlantic croaker (Micropogon undulatus), and note that we have not observed speckled trout at coastal platforms although they may be present, particularly near the beach. Schools of bluefish and some jackfishes like blue runner appear to be quite abundant around coastal platforms at all depths. In the upper and middle part of the water column, Atlantic moonfish are typically abundant at Coastal platforms in Louisiana as are an occasional gray snapper. At coastal platforms more distant from shore, it is not unusual to encounter large schools of baitfish such as round scad, Spanish sardine and scaled sardine (Harengula pensacolae) in the upper part of the water column".

Gallaway and Lewebel (1982) summarized the composition of the assemblage of fishes at Texas coastal platforms studied in the Buccaneer Gas and Oil Field (BGOF; Middleditch, 1981). "The composition and vertical zonation of pelagic fishes around the BGOF structures were similar to those observed at Coastal platforms in Louisiana waters. Spadefish (dominant), sheepshead and barracuda were characteristic of the upper column; red snapper and groupers were common to the bottom and often seen at mid-depths; and schools of bluefish, blue runner and baitfish were common. The fish fauna at BGOF structures differed notably from those in Louisiana in that large schools of lookdown were never observed over the four years of investigation, and by the high abundance of the tomtate. The sciaenid fishes listed by Shinn (1974) were not common to the bottom of BGOF structures, but the cubbyu (Equestus umbrosus) and, sometimes, the bigeye (Priacanthus arenatus) were basically similar to those at Louisiana platforms, including the most common inhabitants, belted sandfish, cocoa damselfish, sergeant major, night sergeant, gray triggerfish and an occasional butterflyfish."

\section{Offshore Platforms}

Gallaway and Lewbel (1982) describe the fish assemblages at two offshore Louisiana platforms: one classified as "ecotonal" between coastal and offshore assemblages and one they consider to represent a true offshore assemblage (Gallaway et al., 1981b). 
"The ecotonal platform in the offshore zone of Louisiana was located at a distance of $42 \mathrm{~km}$ from the shore, in water $35 \mathrm{~m}$ deep. Dominant fishes during the summer were bluefish, spadefish, and mixed schools of lookdown and moonfish. Blue runner, amberjack and almaco jack were common. Sheepshead and gray triggerfish were common but not abundant. Large predators were barracuda, cobia, and nurse shark. Reef fish were not abundant, and included cocoa damselfish, cubbyu, whitespotted soapfish, bigeye and bermuda chub. The snapper grouper assemblage was a major component, and included large groups of gray snapper and medium to small schools of red and lane snapper. Spadefish, lookdown, and gray snapper dominated near the surface; spadefish, bluerunner and gray snapper were most abundant at mid-depth; and snapper were most common at $23 \mathrm{~m}$. Large Atlantic croaker were caught by angling at the bottom.

The spadefish was the dominant pelagic species at the Offshore platform, and most of the other species characteristic of the coastal fish assemblages were also well represented and abundant (lookdown, moonfish, blue runner, sheepshead, gray triggerfish). The assemblage differed from the coastal assemblage in the abundance of gray and red snapper and the richness of the tropical species such as cocoa damselfish, blue and French angelfish, sergeant major, brown chromis, filefishes, tangs, flamefish and the creole fish. Also well represented were the almaco jacks, greater amberjack, bar jack, and rainbow runner. Other large predators included barracuda, crevalle jack, cobia and hammerhead shark."

\section{Bluewater Platforms}

Gallaway and Lewbel (1982) summarized the fish assemblage at blue water platforms in the Northern Gulf of Mexico. "At Bluewater platforms, the huge pelagic schools of spadefish, lookdowns, and bluefish are absent, seemingly replaced by numerous creole fish and almaco jacks along with the ubiquitous blue runner. The grazing sheepshead is replaced by the gray triggerfish and a host of tropical species. In the upper part of the water column down to $30-\mathrm{m}$ depths, mycteropercid groupers and hinds (e.g., Epinephelus adscensionis) are common to abundant. The vertical members of the Bluewater platforms are surrounded by swarms of wrasses (particularly the creole wrasse, Clepticus parrai, and Spanish hogfish (Bodianus rufus) and other tropical species including damselfishes, angelfishes, tangs, rock beauty (Holocanthus tricolor), red spotted hawkfish (Amblycirrhitus pinos) and red hogfish (Decodon puellaris). The most abundant large predator, at least within safe diving depths $(30 \mathrm{~m})$ is the barracuda; hammerhead sharks are also common." 


\subsection{Conceptual Model}

Conceptual models of platform communities have been developed by Gallaway and Margraf (1979), Fucik and Show (1981), Gallaway et al. (1981a) and Gallaway and Lewbel (1982). Darnell and Schmidly (1988) presented a simplified summary model (Figure 4-1).

The fouling mat includes primary producers, attached filter feeders (barnacles, mollusks, sponges, hydroids, bryozoans), and small browsers and detritus feeders trophically dependent on the fouling mat. The fouling mat receives input from sunlight, plankton and nutrients and produces organic detritus which may remain suspended or fall to the bottom. In the surrounding water are the nonattached plankton feeders, mat browsers, detritovores, omnivores and predatory species. Some of these are residents, while others are transient.

Fucik and Show (1981) developed a mathematical model based on the BGOF studies of platforms near Galveston Bay, Texas. This model suggested that the major flow of organic material entered the system through the phytoplankton, zooplankton, plankton feeders, and fouling flora and fauna compartments of the system, and that the other compartments serve to export carbon. Based upon results of simulations of the model, uptake of contaminants in platform discharges appeared limited, in large part, to the fouling community.

\subsection{Application to Ecological Risk Assessment for Produced Water Discharges}

A description of the communities associated with coastal and offshore platforms in the Gulf of Mexico is needed to complete the problem formulation phase of an ecological risk assessment and describe the environment at risk. Community descriptions are also required to identify assessment endpoints. 


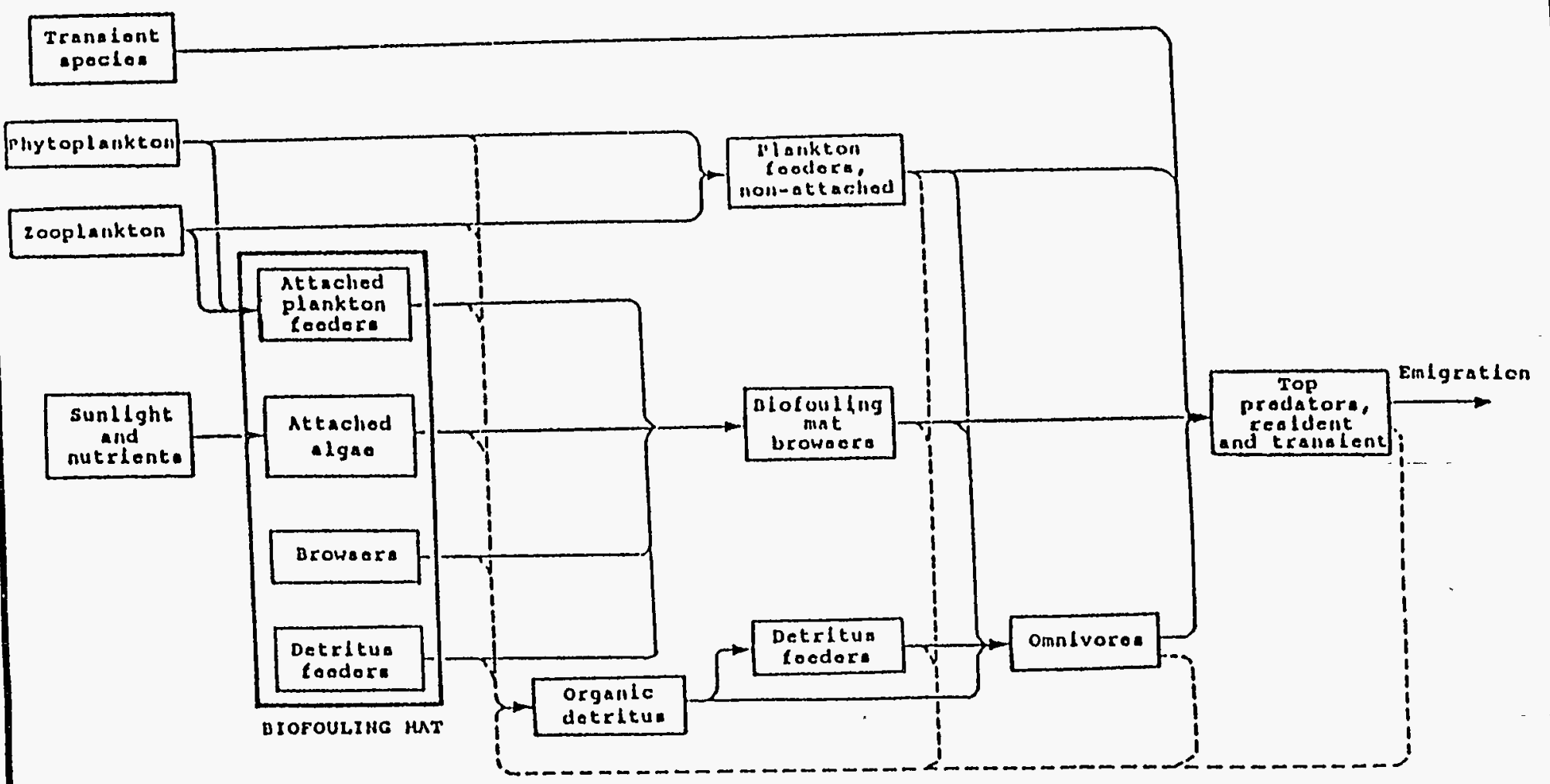

Figure 4-1. Conceptual model of a platform community (from Darnell and Schmidly, 1988). 


\section{ENDANGERED SPECIES AND SENSITIVE ECOSYSTEMS}

\subsection{Introduction}

Endangered species and sensitive ecosystems in the Gulf of Mexico have special social and sometimes ecological value, and represent potential assessment endpoints in ecological risk assessments. The following summaries are based largely on information presented in the Environmental Impact Statements produced by the Department of Interior, Minerals Management Service (DOI, MMS) to assess the potential impacts of proposed oil and gas lease sales on the Gulf of Mexico (MMS, 1994; 1993; 1990).

\subsection{Endangered Species and Marine Mammals}

The Endangered Species Act of 1973 (16 U.S.C. 1531-1543) as amended, and the Marine Mammal Protection Act (MMPA) of 1972 (16 U.S.C. 1361 et seq.) give special protection to endangered and threatened species and to marine mammals. These species are unique in that the risk to individual animals may be of concern.

\section{Marine Mammals}

Marine mammals that occur in the Northern Gulf of Mexico are listed in Table 51. Seven species of baleen whales have been reported in the Gulf of Mexico but are rare: the northern right whale, blue whale, fin whale, sei whale, Bryde's whale, minke whale and the humpback whale. Five of these species are listed as endangered (Table 5-1).

Twenty-five species of toothed whales and dolphins have been reported in the Gulf of Mexico (Table 5-1). The sperm whale is the only one of the toothed whales and dolphins listed as endangered. It is the most abundant large whale in the Gulf of Mexico and tends to occur in deeper water (MMS, 1993).

Common toothed whales and dolphins in the Gulf of Mexico include the grampus, Atlantic bottlenose dolphin, striped dolphin and the Atlantic spotted dolphin (Table 5-1). Bottlenose dolphins are common on the continental shelf and nearshore waters, and Atlantic spotted dolphins frequent mid-shelf to outershelf waters. Grampus are frequently sighted along the shelf edge. The striped dolphin frequents deeper waters. 
Table 5-1. Marine mammals of the central and western Gulf of Mexico (modified from Schmidly and Scarborough, 1990; as cited in MMS, 1993).

\begin{tabular}{|c|c|c|}
\hline Species & Occurrence & Status \\
\hline \multicolumn{3}{|l|}{ Baleen Whales } \\
\hline Northern Right Whale (Eubalaena glacialis) & $\bar{R}$ & 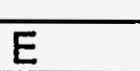 \\
\hline Blue Whale (Balaenoptera musculus) & $\mathrm{R}$ & $\bar{E}$ \\
\hline Fin Whale (Balaenoptera physalus) & $\overline{\mathbf{R}}$ & $\bar{E}$ \\
\hline Sei Whale (Balaenoptera borealis) & $\bar{R}$ & $\bar{E}$ \\
\hline Bryde's Whale (Balaenoptera edeni) & $\mathbf{R}$ & \\
\hline Minke Whale (Balenoptera acutorostrata) & $\mathbf{R}$ & \\
\hline Humpback Whale (Megaptera novaeangliae) & R & $E$ \\
\hline \multicolumn{3}{|l|}{ Toothed Whales and Dolphins } \\
\hline Sperm Whale (Physeter macrocephalus) & C & $E$ \\
\hline Pygmy Sperm Whale (Kogia breviceps) & C & \\
\hline Dwarf Sperm Whale (Kogia simus) & $\bar{U}$ & \\
\hline Sowerby's Beaked Whale (Mesoplodon bidens) & Ext & \\
\hline Blainville's Beaked Whale (Mesoplodon densirostris). & $\bar{R}$ & \\
\hline Antillian Beaked Whale (Mesoplodon europaeus) & $\mathrm{U}$ & \\
\hline Goosebeaked Whale (Ziphius cavirostris) & $\bar{U}$ & \\
\hline Killer Whale (Orcinus orca) & $\bar{R}$ & \\
\hline False Killer Whale (Pseudorca crassidens) & $\bar{U}$ & \\
\hline Pygmy Killer Whale (Feresa attenuata) & $\bar{U}$ & \\
\hline $\begin{array}{l}\text { Short-finned Pilot Whale (Globicephala } \\
\text { macrorhynchus) }\end{array}$ & C & \\
\hline Grampus/Risso's Dolphin (Grampus griseus) & $\mathrm{U}$ & \\
\hline Melon-headed Whale (Peponocephala electra) & $\mathrm{R}$ & \\
\hline Atlantic Bottlenose Dolphin (Tursiops truncatus) & $\mathrm{C}$ & \\
\hline Saddleback Dolphin (Delphinus delphis) & $\overline{\mathbf{R}}$ & \\
\hline Rough Toothed Dolphin (Steno bredanensis) & $\bar{R}$ & \\
\hline Striped Dolphin (Stenella coeruleoalba) & $\mathrm{C}$ & \\
\hline Pantropical Spotted Dolphin (Stenella attenuata) & $\mathbf{R}$ & \\
\hline Short-snouted Spinner Dolphin (Stenella chymene) & $\bar{U}$ & \\
\hline Atlantic Spotted Dolphin (Stenella frontalis) & $\mathrm{C}$ & \\
\hline Long-snouted Spinned Dolphin (Stenella longirostris) & $\bar{U}$ & \\
\hline Fraser's Dolphin (Lagenodelphis hosel) & $\bar{R}$ & \\
\hline
\end{tabular}

$C=$ common, $U=$ uncommon, $R=$ rare, Ext = extralimital record

$E=$ endangered 


\section{Endangered and Threatened Species}

Endangered and threatened species in the Northern Gulf of Mexico potentially impacted by produced water discharges are listed in Table 5-2 (biological opinions in MMS, 1993). This list does not include all endangered and threatened species in the region but is restricted to: those identified as potentially impacted by the Fish and Wildlife Service (FWS) and the National Marine Fisheries Service (NMFS) in the biological opinions referenced in the Environmental Impact Statements for the central and western Gulf of Mexico (MMS, 1993); all marine turtles that occur in the Gulf of Mexico; and all marine mammals that occur in the Gulf of Mexico. No terrestrial organisms have been included.

\section{Coastal and Marine Birds}

Endangered and threatened species of Coastal and Marine Birds potentially impacted by produced water discharges include the brown pelican, bald eagle, arctic peregrine falcon, piping plover and the whooping crane (Table 5-2).

The brown pelican is classified as an endangered species except along the U.S. Atlantic coast, Florida and Alabama. The brown pelican is rarely found away from saltwater, and does not move more than 20 miles out to sea. Feeding is by plunge-diving for fish in coastal waters.

The bald eagle is listed as endangered in most of the conterminous U.S., and as threatened in WA, OR, MN, WI and MI. The bald eagle eats primarily fish, combined with opportunistic capture of small vertebrates.

The arctic peregrine falcon is listed as a threatened species, and is a subspecies of the peregrine falcon of North America. The arctic peregrine falcon nests in tundra areas of North America and Greenland, and migrates south to the Gulf coast, West Indies and Central and South America. The arctic peregrine falcon feeds on a wide variety of birds. Migrant arctic peregrine falcons concentrate on beaches, flats and wetlands along the Gulf coast.

The piping plover is listed as endangered in the Great Lakes watershed and as threatened in the remainder of its range, including the Gulf Coast. Nesting areas include the Central and North Atlantic seaboard of the U.S., Atlantic Canada, the Great Lakes and a portion of the Northern Great Plains. The piping plover winters on the Atlantic Ocean and Gulf Coasts and on Caribbean islands. Texas is an important wintering area, and the Louisiana barrier islands provide favorable habitat.

The whooping crane is listed as an endangered species. The wintering range of the entire reproducing population of the whooping crane is along the Texas 
coast. There is an experimental population established in southeastern Idaho. Whooping cranes feed on crabs and clams in tidal flats, shallow bays and channels.

\section{Fishes}

One species of fish listed as threatened is potentially affected by produced water discharges - the Gulf Sturgeon (a subspecies of the Atlantic sturgeon). The Gulf Sturgeon is anadromous and is known to occur on most major rivers from the Mississippi River to the Suwannee River and in marine waters of the central and eastern Gulf of Mexico. Adults and immature fish spend eight to nine months in rivers and three to four of the coldest months in estuaries or the Gulf of Mexico.

\section{Marine Turtles}

Five species of marine turtles occur in the Gulf of Mexico, and all are listed as threatened or endangered.

The loggerhead turtle is the most abundant species of marine turtle in Gulf of Mexico waters, and is listed as a threatened species. Loggerheads inhabit coastal areas of the continental shelf and are most common in water less than $50 \mathrm{~m}$ deep, but are also found in deep water (NMFS, biological opinion in MMS, 1993).

Green turtles are listed as threatened species, except for breeding populations in Florida and on the Pacific coast of Mexico where they are listed as endangered. The green turtle was once a commercial fishery in inshore Texas Bays but the population has not recovered from over-exploitation. Green turtles prefer depths less than $20 \mathrm{~m}$, and the only major feeding grounds for the juvenile and subadult Green Turtle in the Gulf of Mexico is the upper west coast of Florida. Older green turtles are unlikely to reside permanently in most areas of the Gulf of Mexico because of the scarcity of sea grass pastures (NMFS Biological Opinion in MMS, 1993).

Leatherbacks are the largest and most oceanic marine turtle, and feed primarily on jellyfish. They are distributed throughout the Atlantic, Pacific, Caribbean and the Gulf of Mexico. Nesting is concentrated in the tropical latitudes, but there are occurrences in Florida. The leatherback turtle is listed as endangered.

The hawksbill turtle is relatively uncommon in the northern Gulf of Mexico, and is listed as endangered. Hawksbill turtles prefer reefs and shallow coastal waters, and are more common in tropical areas of the Atlantic, Gulf of Mexico and Caribbean. 
The Kemp's ridley turtle is the most endangered of the sea turtles. The only major nesting area is on a stretch of beach in Rancho Nuevo, Mexico. Limited nesting occurs on Padre and Mustang Islands in Texas, and the NMFS oversees a hatching and rearing program on Padre Island. The foraging range of the Kemp's ridely turtle is restricted to the Gulf of Mexico. These turtles feed primarily in shallow coastal waters on bottom-living crustaceans.

\section{Marine Mammals}

Threateried and Endangered species of marine mammals in the Northern Gulf of Mexico include the northern right whale, blue whale, fin whale, sei whale, humpback whale and the sperm whale (Table 5-2 ; see previous discussion).

Table 5-2. Endangered and threatened species in the northern Gulf of Mexico potentially impacted by produced water discharges (MMS, 1993).

\begin{tabular}{|l|l|}
\hline Species & Status \\
\hline Coastal and Marine Birds & \\
\hline Brown Pelican (Pelicanus occidentalis) & \\
\hline Bald Eagle (Haliaeetus Leucocephalus) & E \\
\hline Arctic Peregrine Falcon (Falco peregrinus tundrius) & E \\
\hline Piping Plover (Charadrius melodus) & T \\
\hline Whooping Crane (Grus americana) & T \\
\hline & E \\
\hline Fishes & \\
\hline Gulf of Mexico Sturgeon (Acipenser oxyrhnchus) & \\
\hline Marine Turtles & T \\
\hline & \\
\hline Green Turtle (Chelonia mydas) & \\
\hline Kemp's Ridley Turtyle (Lepidochelys kempi) & T \\
\hline Hawksbill Turtle (Eretmochelys imbricata) & E \\
\hline Loggerhead Sea Turtle (Caretta caretta) & E \\
\hline Leatherback Sea Turtle (Dermochelys coriacea) & T \\
\hline Marine Mammals & E \\
\hline & \\
\hline Northern Right Whale (Eubalaena glacialis) & \\
\hline Blue Whale (Balaenoptera musculus) & E \\
\hline Fin Whale (Balaenoptera physalus) & E \\
\hline Sei Whale (Balaenoptera borealis) & E \\
\hline Humpback Whale (Megaptera novaeangliae) & E \\
\hline Sperm Whale (Physeter macrocephalus) & E \\
\hline E & E \\
\hline
\end{tabular}

$E=$ endangered; $T=$ threatened 


\subsection{Unique and Sensitive Ecosystems}

Unique and sensitive biological resources of the Gulf of Mexico include coastal wetlands, the pinnacle trend live bottom features, topographic features inhabited by hard-bottom benthic communities, and deep water chemosynthetic benthic communities. The Minerals Management Service (MMS) describes these biological resources in detail in the Environmental Impact Statements developed for proposed oil and gas lease sales in the Gulf of Mexico outer continental shelf (OCS) (MMS, 1994; 1993). The following descriptions are abstracted from MMS (1993); see this source for more detail and original data sources.

\section{Wetlands}

Wetlands along the Gulf Coast include fresh, brackish and saline marshes, forested wetlands and small areas of mangroves. Coastal wetlands are characterized by high organic productivity, high detritus production, and efficient nutrient recycling (MMS, 1993). Wetlands provide habitat for a great number and diversity of invertebrates, fish, reptiles, birds and mammals, and are important nursery grounds for many species of fish. Figure 5-1 shows the extensive wetlands along the coast of Louisiana.

\section{Live-Bottoms (Pinnacle Trend)}

The pinnacle trend is a region of topographic relief in the northwestern Gulf of Mexico between 67 and $110 \mathrm{~m}$ in depth that appears to be carbonate reef structures in an intermediate stage between growth and fossilization. Additional features occur outside of the identified pinnacle trend. The pinnacles provide surface area for the growth of sessile invertebrates and attract large numbers of fish. In a study of hard bottom features, Continental Shelf Associates (1992a) found that biological communities were dominated by tropical and subtropical suspension-feeding invertebrates.

\section{Topographic Features}

The shelf and shelf edge of the central and western Gulf of Mexico contain topographic features or banks inhabited by hard-bottom benthic invertebrates. These areas are important because they support hard-bottom communities of high diversity and high biomass and large numbers of recreationally and commercially important fish. Topographic features are also unique in that they are small and isolated areas in a region of much lower diversity (MMS, 1993). These topographic features present proper conditions for coral growth. Seven distinct biotic zones have been identified (Rezak et al., 1985) and are described in more detail in MMS (1993). Figure 5-2 shows the location of major topographic features in the Gulf of Mexico. The East and West Flower Garden 
Banks are of particular interest due to the extensive development of the hermatypic coral reef community, and have been designated a National Marine Sanctuary.

\section{Deepwater Chemosynthetic Benthic Communities}

Chemosynthetic clams, mussels and tube worms have been discovered in deep waters of the Gulf of Mexico (MMS, 1993; Figure 5-3). These chemosynthetic communities are associated with hydrocarbon and $\mathrm{H}_{2} \mathrm{~S}$ seep areas at water depths greater than $400 \mathrm{~m}$. The communities are characterized by bacterial mats, dense beds of tube worms, clams and mussels, numerous small gastropods and galatheid crabs (MMS, 1993). The worms, clams and mussels contain autotrophic bacterial symbionts (Brooks et al., 1987).

\subsection{Application to Ecological Risk Assessment for Produced Water Discharges}

Descriptions of the major ecosystems and biota potentially at risk will support the problem formulation step in an ecological risk assessment, including the identification of assessment endpoints in a specific analysis. Endangered species and sensitive ecosystems represent unique social values and should be considered in identifying assessment endpoints 


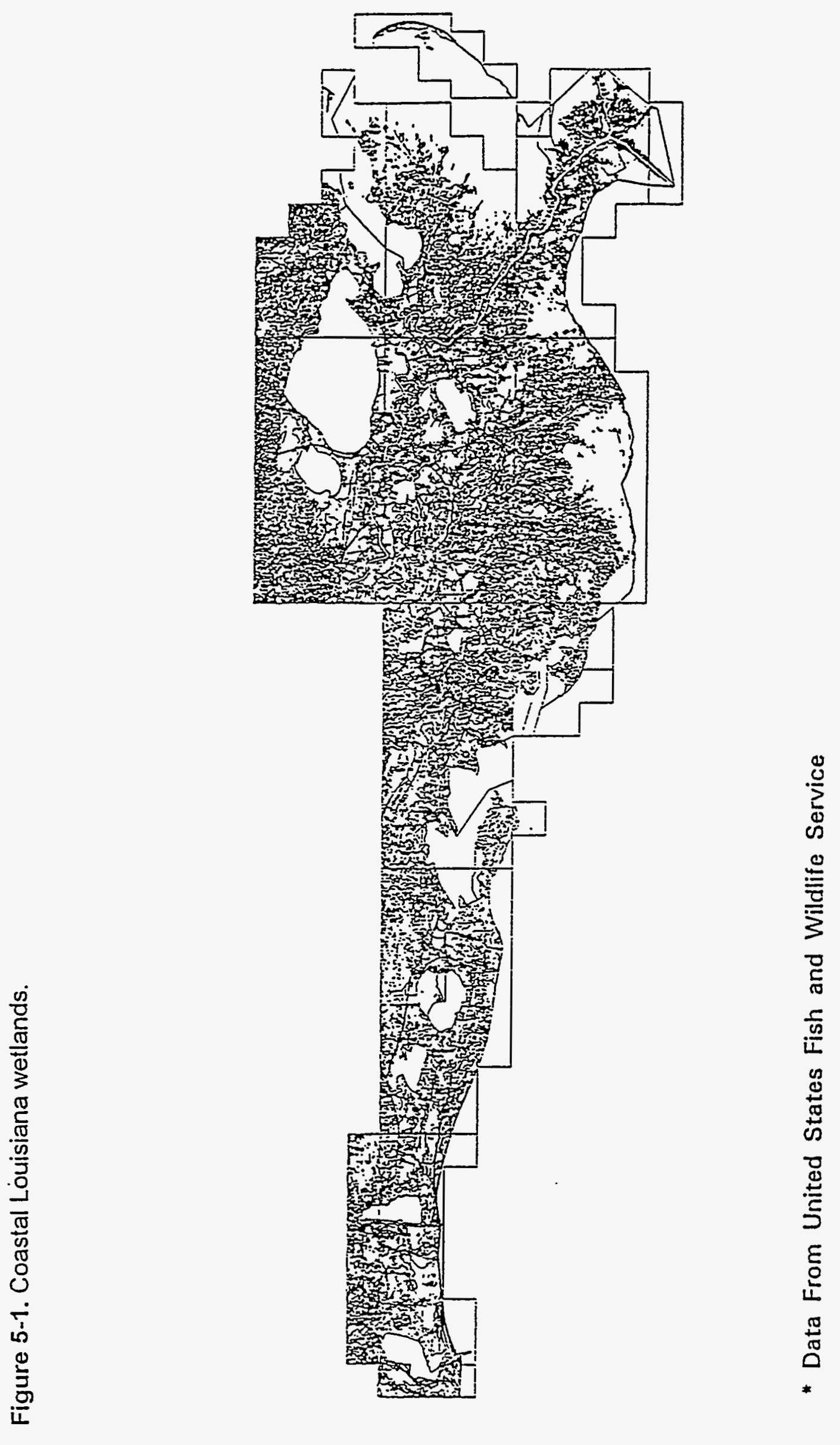




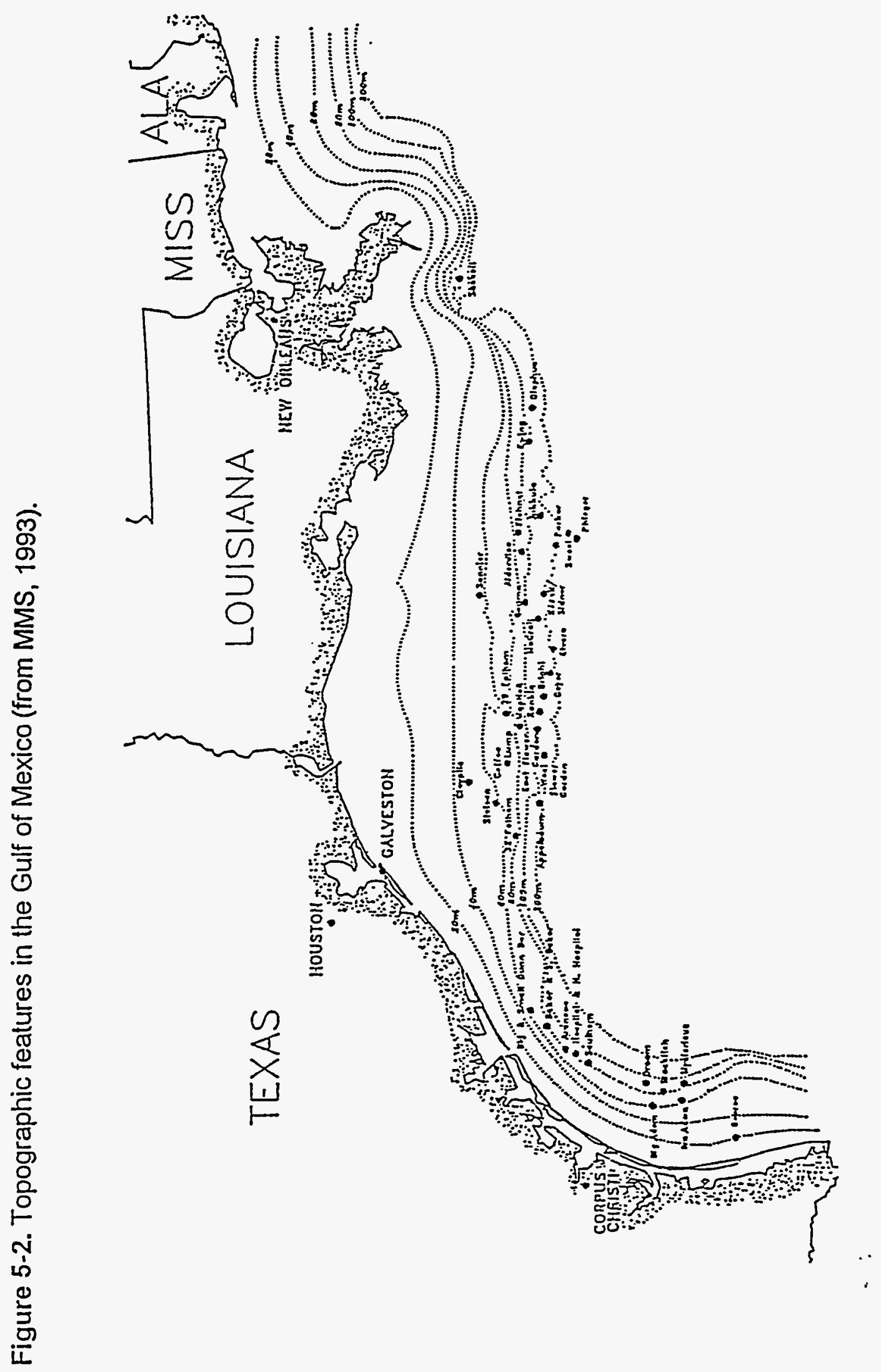




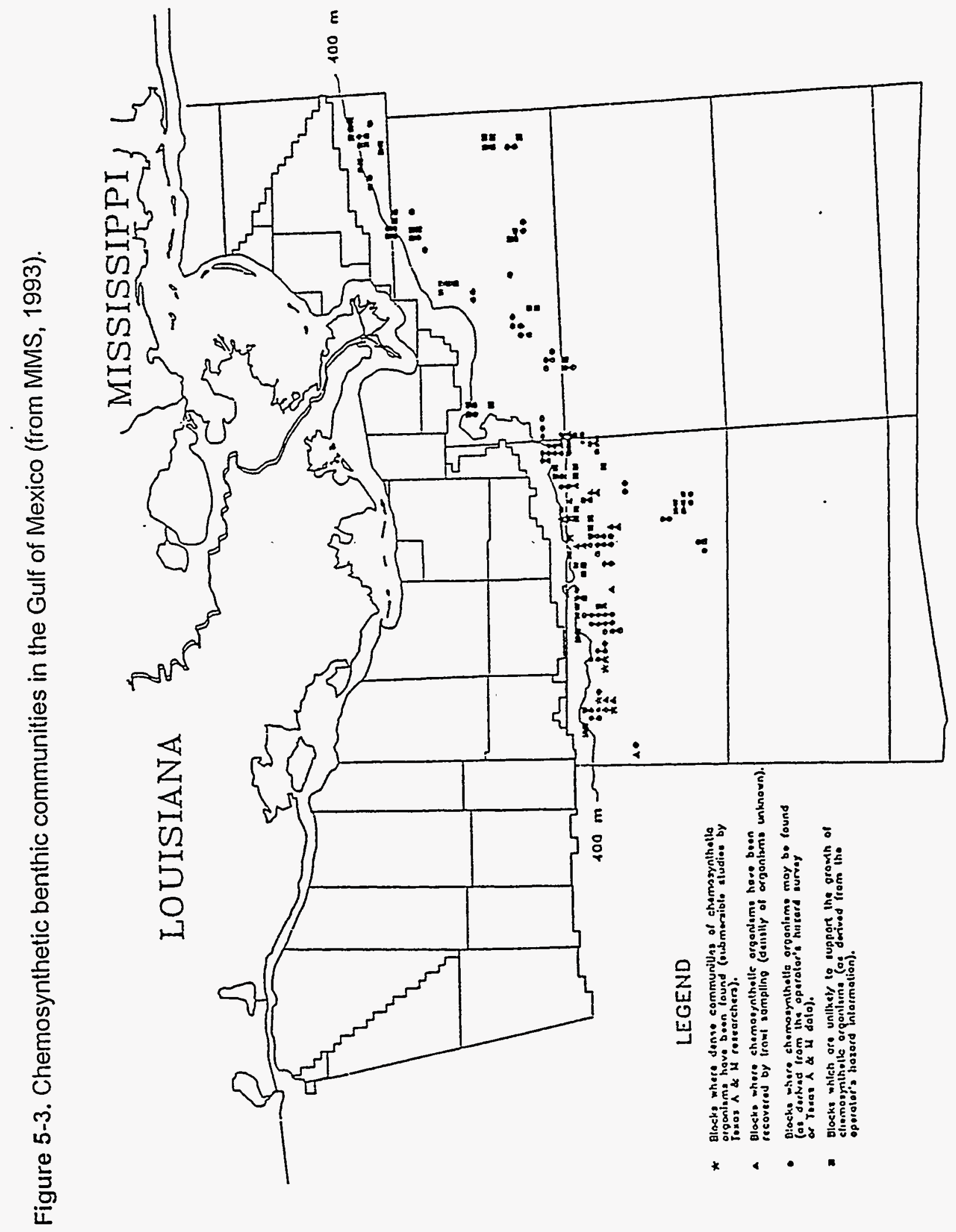




\section{CHEMICAL/PHYSICAL CHARACTERIZATION OF PRODUCED WATER}

\subsection{Introduction}

Produced waters usually have high total dissolved solids (salinity) and total organic carbon, and are low in dissolved oxygen. Other components of potential concern include metals, dissolved and dispersed petroleum hydrocarbons, various treatment chemicals, and radionuclides.

Detected contaminants and contaminant concentrations in produced water vary widely, because the characteristics of the saline water and oil in the formation varies and because treatment methods and treatment efficiencies vary over time and space. The following sections summarize ranges of contaminant concentrations in produced waters and produced water discharge rates.

\subsection{Conventional Pollutants, Heavy Metals and Organics}

Produced waters are brine solutions with an ionic composition similar to, but usually more concentrated that of seawater (Neff et al., 1987). The concentration of total dissolved solids (TDS) ranges from a few parts per thousand (ppt) to $300 \mathrm{ppt}$ (MMS, 1993). Most produced waters have higher TDS than seawater (35 ppt).

Metals that have been measured in produced waters at concentrations greater than seawater include aluminum, barium, beryllium, cadmium, chromium, copper, iron, lead, manganese, mercury, nickel, silver vanadium and zinc (MMS, 1993). Concentrations of metal discharges in produced waters vary widely.

Produced waters contain petroleum components, with volatile and soluble acidextractable components present in higher concentrations than the heavier components (PAHs) (Middleditch, 1984; St. Pé, 1990).

Treatment chemicals are added to treat or prevent operational problems. Production treating chemicals include: scale and corrosion inhibitors, biocides, emulsion breakers, water treating chemicals (coagulants, floculants and reverse emulsion breakers), antifoams and paraffin/asphaltene treating chemicals (Stephenson, 1991). Biocides used at the Buccaneer Gas and Oil Field (Rose and Ward, 1981; Zein-Eldin and Keney, 1979) were K-31 pentanectialdehyde and KC-14 alkyldimethyl benzyl chloride. There were replaced by a formulation of acrolein (2-propenal) of about 90 to $94 \%$ purity. Acrolein is a highly volatile, toxic, and reactive substance. Residual acrolein in produced water is scavenged by treatment with sodium bisulfite prior to discharge.

A number of investigators have summarized ranges of major contaminants in produced water effluents (Stephenson, 1992; Neff et al., 1989; Middleditch, 
1981). Table 6-1 summarizes some of the more recent data collected in the Gulf of Mexico for heavy metals and organics. Concentrations of all major components vary widely.

\subsection{Radionuclides}

Naturally occurring radioactive materials (NORM) present in produced water discharges include ${ }^{226} \mathrm{Ra}$ and ${ }^{228} \mathrm{Ra}$, radon, ${ }^{210} \mathrm{~Pb},{ }^{210} \mathrm{Po}$, and probably other members of the ${ }^{238} \mathrm{U}$ and thorium decay series. Radionuclide concentrations in produced water are influenced by differences in solubility in the formation, and the nuclides are not in secular equilibrium with their parent compounds.

No comprehensive sampling program has been conducted to document the concentrations and amounts of radium being discharged to the Gulf of Mexico. There are, however, data available for a limited number of produced water discharges (Table 6-2). Few data are available for radionuclides other than radium.

\subsection{Discharge Rates}

Discharge rates of produced waters are important because the total amount of contaminant discharged to the environment per unit time (i.e. discharge rate times the concentration of contaminant in the discharge) is of more interest in terms of potential environmental effects than is simply the concentration in the effluent. Over the life of a well, the volume of water produced often increases as the volume of oil or gas decreases. In many of the older fields in the coastal waters of Louisiana and Texas, production may be $95 \%$ water and 5 percent oil or gas (Neff et al., 1989). Produced water discharge rates for oil wells in the Gulf of Mexico range from $0.5 \mathrm{bbl} / \mathrm{d}$ to more than $187,000 \mathrm{bbl} / \mathrm{d}$ (Table 6-3).

\subsection{Application to Ecological Risk Assessment for Produced Water Discharges}

Data describing the contaminant concentrations and discharge rates of produced water are needed to formulate the problem, identify potential impacts and describe the source term for an ecological risk assessment. Data presented here are limited and additional data derived from permit files and other sources may be needed in a site or area specific assessment. 
Table 6-1. Ranges of metals and organic contaminant concentrations in produced waters $(\mu \mathrm{g} / \mathrm{l})$.

\begin{tabular}{|c|c|c|c|}
\hline Contaminant & $\begin{array}{l}\text { USEPA } \\
(1993 d)^{1}\end{array}$ & SAIC (1991) & $\begin{array}{l}\text { St. Pé } \\
(1990)^{3}\end{array}$ \\
\hline \multicolumn{4}{|l|}{ Organics } \\
\hline benzene & $2,978.69$ & $52.48-9008.41$ & $500-1,200$ \\
\hline ethylbenzene & 323.62 & $23.80-1009.27$ & $9.4-29$ \\
\hline chlorobenzene & 19.47 & 47.50 & \\
\hline toluene & $1,897.11$ & $80.83-5305.44$ & $150-580$ \\
\hline total xylenes & 695.03 & $12.51-439.37$ & $58-210$ \\
\hline di-n-butylphthalate & 16.08 & 10.0 & \\
\hline 2-butanone & $1,028.96$ & $275.00-1254.80$ & \\
\hline phenol & $1,538.28$ & $10.00-379.83$ & $240-890$ \\
\hline p-chloro-m-creosol & 25.24 & $10.00-364.17$ & \\
\hline steranes & 77.50 & & \\
\hline triterpanes & 78.00 & & \\
\hline creosols & & & $370-850$ \\
\hline 2,4 dimethylphenol & 317.13 & $10.00-146.70$ & \\
\hline PAHs & & & $19-47$ \\
\hline anthracene & 18.51 & 10.00 & ND - 0.56 \\
\hline benzo (a) pyrene & 11.61 & 10.00 & - \\
\hline chrysene & & & $<0.18-1.9$ \\
\hline naphithalene & 243.58 & $18.60-71.70$ & $18-41$ \\
\hline fluoranthene & & & $<0.17-0.56$ \\
\hline fluorene & & & $0.33-2.8$ \\
\hline phenanthrene & & & $0.49-9.2$ \\
\hline pyrene & & & $<0.17-0.67$ \\
\hline \multicolumn{4}{|l|}{ Metals } \\
\hline aluminum & 78.01 & $35.00-122.98$ & $<0.44$ \\
\hline arsenic & 114.19 & $17.00-308.56$ & $<0.11-87$ \\
\hline barium & $55,563.80$ & $49.67-65853.79$ & $1,521-4,644$ \\
\hline boron & $25,740.25$ & $6850.96-38230.13$ & \\
\hline cadmium & 22.62 & 4.00 & $<0.06$ \\
\hline chromium & & & $<0.01-0.41$ \\
\hline copper & 444.66 & $6.00-135.50$ & $<0.05-58$ \\
\hline iron & $4,915.87$ & $672.29-8260.75$ & \\
\hline lead & 195.09 & 50.00 & $<0.08$ \\
\hline mercury & & & $<1.7$ \\
\hline manganese & 115.87 & $90.68-230.90$ & \\
\hline nickel & $1,705.46$ & 30.00 & $<0.22$ \\
\hline titanium & 7.00 & $3.66-12.06$ & \\
\hline vanadium & & & $1.2-60$ \\
\hline zinc & $1,190.13$ & $23.23-72.32$ & $7.3-25$ \\
\hline
\end{tabular}

Table IX-15 in USEPA (1993d), baseline effluent characteristics for priority pollutants achievable by BPT technology based on several industry and EPA databases.

Three facility study, data abstracted from USEPA (1993d)

4 produced water discharges to coastal environments in Louisiana. 
Table 6-2. Radionuclides in produced water discharges in the Gulf of Mexico (pCi/l).

\begin{tabular}{|c|c|c|c|c|}
\hline Reference & ${ }^{226} \mathrm{Ra}$ & ${ }^{228} \mathrm{Ra}$ & ${ }^{226} \mathrm{Ra}+{ }^{228} \mathrm{Ra}$ & ${ }^{210} \mathrm{~Pb}$ \\
\hline Stephenson and Supernaw $(1990)^{1}$ & $4-584$ & $18-586$ & - & - \\
\hline USEPA (1993b) & $0-450$ & $0-560$ & - & - \\
\hline Rabalais et al.o, $(1991)^{3}$ & - & - & $152-1156$ & $0.11-12.7$ \\
\hline St.Pé ' (1990) & - & $355-567$ & - & - \\
\hline Continental Shelf Associates (1991) & $111-252$ & $244-383$ & - & - \\
\hline Continental Sheif Associates (1992b) & $111-225$ & $240-520$ & - & $<10.6$ \\
\hline Steimle \& Associates (1992) & $50.1-190$ & $48.2-198$ & - & - \\
\hline Neff et. al., $(1989)^{8}$ & - & - & $605-1215$ & - \\
\hline
\end{tabular}

42 Offshore platforms in Louisiana

83 outfalls in Louisiana territorial seas

7 discharges of OCS produced waters into Louisiana coastal environments

4 produced water discharges to coastal sites in Louisiana

3 coastal discharges in Louisiana

2 offshore platforms in the northern Gulf of Mexico

1 offshore, 2 inshore outfalls in Louisiana

8 platforms, 1 shallow bay, 3 offshore in Louisiana

Table 6-3. Produced water discharge rates for offshore and coastal discharges in the Gulf of Mexico.

\begin{tabular}{|l|c|c|c|}
\hline Source & \multicolumn{3}{|c|}{ Discharge Rate (bbl/day) } \\
\hline & mean & std. deviation & range \\
\hline OOC $^{\prime}$ & & & $8-22880$ \\
\hline LDEQ $^{2}$ & 6034 & 5852 & $0.5-187420$ \\
\hline COMBINED $^{3}$ & 8278 & 24418 & $0.5-187420$ \\
\hline & 7518 & 20175 & \\
\hline
\end{tabular}

1 Offshore Operators Committee (42 offshore outfalls; Stephenson and Supernaw, 1990)

${ }^{2}$ Louisiana Dept. of Environmental Quality (83 outfalls, coastal and offshore within state waters; USEPA, 1991)

${ }^{3}$ Combined two data sets 


\section{PRODUCED WATER TOXICITY}

\subsection{Introduction}

Produced water contains chemical and radioactive contaminants, and has properties that could cause harmful effects in marine organisms and ecosystems. These include elevated salinity, altered ion ratios, low dissolved oxygen, petroleum hydrocarbons and other organics, and heavy metals. Since most produced waters have dissolved solids concentrations higher than that of sea water (30-39 ppt), discharge of such waters to the ocean results in a localized elevation in salinity. Also, the concentration ratios of several major ions (particularly calcium and magnesium) in produced water may be markedly different than those of sea water, leading to adverse reactions in organisms in the receiving waters (Neff et al., 1989). However, mixing and dilution of produced water discharged into deep water offshore regions is rapid, and concentrations of contaminants may be undetectable more than a few meters from the discharge point. Conversely, coastal discharges into poorly flushed brackish or saline systems show a significant possibility for toxicity (St. Pé, 1990).

Toxicity tests are useful analytical tools because they can directly measure potential aquatic effects compared to chemical analyses which are difficult to extrapolate. This is particularly true in the case of complex effluents, such as produced water, where a broad range of toxicants can be present in low levels. Produced water test procedures usually use mortality as the measured response with results of acute tests expressed as an effluent median lethal concentration for an exposure duration of $96 \mathrm{hrs}$ (96-hr LC $\mathrm{L}_{50}$ equals the effluent concentration which results in the mortality of $50 \%$ of the test organisms in a 96-hr exposure period). This section summarizes available toxicity test data for produced water obtained in laboratory and field settings.

\subsection{Laboratory Bioassays}

Results of produced water bioassays conducted in the laboratory range from providing evidence of very low toxicity (Middleditch, 1984), to showing that produced water was highly toxic (Federal Register, 1992). This could be due to differences in the toxicity of the produced water, problems with protocols used in testing, or the presence of biocides in some discharges.

In evaluating these studies several potential flaws and uncertainties should be kept in mind. One problem concerns the maintenance of appropriate oxygen. levels in the test medium. Adequate oxygen levels are usually obtained by aeration, but this can lead to losses of the lighter (more toxic) chemicals. Another significant problem with laboratory bioassays is that the composition of produced waters is almost inevitably altered during transportation and storage. 
Bioassay media are prepared by volumetric additions of produced water to receiving water or filtered sea water according to standard protocols. Exposure concentrations may be measured in terms of nominal volume of produced water added per volume of dilution water. Storage samples should be monitored for production of hydrogen sulfide, generated by reduction of sulfur and sulfate by sulfate-reducing bacteria. This may affect the sample's toxicity.

\subsubsection{NPDES Permitting Data}

The largest produced water toxicity data base used in permitting applications consists of self-monitoring compliance data required by the Louisiana Department of Environmental Quality (LDEQ) discharge permits (Federal Register, 1992; Avanti Corporation, 1993; Table 7-1).

$\mathrm{LC}_{50} \mathrm{~S}$ for mysids (Mysidopsis bahia) ranged from $0.05 \%$ to $>100 \%$ effluent, with a mean 96 -hour $\mathrm{LC}_{50}$ of $12.1 \%$. LC 50 for sheepshead minnow (Cyprinodon variegatus) ranged from $1.17 \%$ to $>100 \%$, with a mean of $27.4 \%$.

Table 7-1. Toxicity data, Louisiana DEQ NPDES permits (modified from Avanti Corporation, 1993).

\begin{tabular}{|c|c|c|c|c|c|c|c|}
\hline & \multicolumn{4}{|c|}{ Mysidopsis bahia } & \multicolumn{3}{|c|}{ Cyprinodon variegatus } \\
\hline & $96-\mathrm{hr} L \mathrm{C}_{50}$ & Survival & Growth & Fecundity & 96-hr LC 50 & Survival & Growth \\
\hline $\begin{array}{l}\text { Number of } \\
\text { Outfalls }\end{array}$ & 241 & 226 & 221 & 150 & 239 & 221 & 218 \\
\hline Mn & & & & 611 & 271 & 804 & 823 \\
\hline Mean & 12.1 & 4.51 & 5.92 & 6.44 & 21.4 & 8.04 & 8.23 \\
\hline Median & 8.20 & 2.16 & 2.08 & 3.00 & 17.9 & 2.50 & 4.90 \\
\hline Minimum & 0.05 & 0.04 & 0.06 & 0.13 & 1.17 & 0.14 & 0.15 \\
\hline Maximum & 100 & 100 & 100 & 100 & 100 & 100 & 100 \\
\hline & & & & & & & \\
\hline $\begin{array}{l}\text { 95th } \\
\text { percentile }\end{array}$ & 1.31 & 0.19 & 0.34 & 0.29 & 2.69 & 0.50 & 0.56 \\
\hline & & & & & & & \\
\hline
\end{tabular}

\subsubsection{The Buccaneer Gas and Oil Field Study (BGOF)}

The BGOF study has been summarized by Middleditch (1984) and Neff (1987). The BGOF, southeast of Galveston Texas, was $59.3 \mathrm{~km}^{2}$ (22.9 sq. statute miles) in area. The field contained two production platforms, two quarters platforms, and well jackets surrounded by 13 satellite structures. Middleditch (1984) summarized the observations of two complex series of laboratory bioassays of produced water samples from the BGOF (Zein-Eldin and Keney, 1979; Rose and Ward, 1981). Apparently contradictory results were explained on the basis of 
presence or absence of biocides in the produced water effluents (Middleditch, 1984).

\section{Biocides}

Biocides were added to product streams to protect pipes and storage vessels by reducing formation of corrosive sulfates by sulfur oxidizing bacteria. During the first series of the BGOF study bioassays, gluteraldehyde (K-31) and alkyldimethylbenzyl chloride(KC-14), and a surfactant were used. To increase biocidal activity, these agents were replaced by acrolein, a very reactive toxin that is also highly volatile. Before discharge, produced water was treated for residual acrolein by using a scavenger, sodium bisulfite. Biocide treatment was not an apparent factor in the second series of bioassay tests because of removal of acrolein by sodium bisulfite. Acrolein was not detected in produced water sampled during the second series of the BGOF study (Middleditch, 1984).

\section{Bioassay results}

Acute toxicity ( $96 \mathrm{hr} \mathrm{LC}_{50}$ ) tests were used in each of the two series of bioassays. The first series of bioassays (Zein-Eldin and Keney, 1979) used juvenile brown shrimp (Penaeus aztecus) and juvenile white shrimp ( $P$. setiferous), under static conditions.

Samples of produced water for the first series were collected from June 1977 through February 1978. Acute toxicities in the first series were high (low LC 50 values; 1,750 to $6,500 \mathrm{ppm}$ of produced water diluted in sea water) when K-31 and $\mathrm{KC}-14$ biocides were added to production streams, and low (high $\mathrm{LC}_{50}$ values may be $>10,000 \mathrm{ppm}$ ) in the absence of biocide treatment. Although oxygen demand increased during the four days of static testing, there were no significant differences between control and experimental groups.

Other experiments in the first series used acute toxicity testing, after chronic exposure to either synthetic control feeds or experimental feeds (soaked in produced water). After preconditioning with either control or experimental diets, half of each dietary group was subjected to $96 \mathrm{hr}$ exposure to $5,000 \mathrm{ppm}$ of produced water in seawater, while the other half of each group was exposed to sea water only. Prior exposure to produced-water apparently increased the responses of juvenile shrimp to produced water, as indicated by:

1. lower $L C_{50}$ values (higher mortality) in animals preconditioned with feed soaked in produced water; and

2. increased oxygen demand in acutely-tested groups of animals preconditioned with feed soaked in produced water. 
The second series of bioassays (Rose and Ward, 1981) used larval and adult brown and white shrimp, barnacles (Balanus tintinnabulum), and crested blennies (Hypleurochilus geminatus), under static and nonstatic conditions. Produced water was sampled from summer 1978 through spring 1979. Results of testing at four different temperatures $\left(18,22,24\right.$ and $\left.25^{\circ} \mathrm{C}\right)$ indicated that 96 $\mathrm{hr} \mathrm{LC}_{50}$ values were similar for adult crustaceans, shrimp and barnacles. Larval brown shrimp were the most sensitive test animals, and blennys were most resistant to the toxic effects of produced water.

$L C_{50}$ values were generally lower at higher temperatures. Barnacles and blennys were more sensitive to unaerated than aerated produced water, a possible effect of ammonium bisulfite treatment, or differences in oxygen demand of produced water. Neff (1987) pointed out that aeration has a rapid stripping effect on volatile low molecular weight aromatic hydrocarbons, such as those found in produced water from the BGOF, and that these hydrocarbons may have contributed to the results for unaerated produced water.

\subsubsection{Offshore Operators Committee (1992)}

Produced-water toxicity data from offshore wells were submitted to USEPA by the Offshore Operators Committee (Federal Register, 1992). Seven-day chronic survival data from one company had a mean survival no effects concentration (NOEC) for mysids of $0.86 \%$ effluent (minimum $0.32 \%$; maximum $1.86 \%$ ) and a mean survival NOEC for sheepshead minnows of $1.0 \%$ effluent (minimum $0.26 \%$; maximum $2.7 \%$ ). Seven-day chronic survival data from another company showed a mean NOEC for mysids of $0.95 \%$ effluent (minimum $<0.1 \%$; maximum $5 \%)$.

\subsubsection{St. Pé (1990)}

St. Pé (1990) studied the toxicity of produced water discharged at 4 coastal sites in Louisiana. One effluent and one sediment sample were analyzed from each of the four study sites; Lirette site; Delta Farms site; Bully Camp site, and the, Lake Washington site. The effluent samples were analyzed using $C$. variegatus and $M$. bahia in toxicity tests.

Test procedures Acute toxicity tests were performed on one effluent sample, from each of the four study sites. A standard USEPA method was used (USEPA, 1985). LC 50 (24-hr, 48-hr, and 96-hr) values with $95 \%$ confidence levels were calculated by the Binomial Method. Both salinity adjusted and unadjusted tests were run. The unadjusted data are emphasized by St Pé (1990) and are discussed below. 
Effluent toxicity Results are summarized in Table 7-2. All tested samples were toxic to $M$. bahia. Salinity readings ranged from 115.2 in Delta Farms to 148.4 in Lake Washington. Salinity readings and toxicity levels did not follow a pattern in these samples; Lake Washington had the highest salinity reading and second highest 96 -hr $\mathrm{LC}_{50}$ value (5.23\%), Delta Farms had the lowest salinity reading and the second lowest $96-\mathrm{hr} L \mathrm{CC}_{50}$ value (3.54\%).

Although high salinity can result in toxicity to mysids, it did not appear to be the major cause of toxicity. The salinity range of the $96-\mathrm{hr} L \mathrm{LC}_{50}$ values was 23.37 ppt to $31.45 \mathrm{ppt}$. These values are in the range at which mysids are successfully cultured. St. Pé (1990) concluded that toxicity of the effluents was due to a component of the effluent other than salinity.

Sheepshead minnows exhibited acute toxicity from all samples (Table 7-2). The salinity range of the $96-\mathrm{hr} L \mathrm{LC}_{50}$ effluent concentrations was $26.82 \mathrm{ppt}$ to 58.06 ppt. Again, the salinity and the toxicity levels did not follow similar patterns: Delta Farms had the lowest salinity reading and the highest $L_{50}$ value. Although high salinity can be toxic to $C$. variegatus, it does not appear to be the major cause.

Table 7-2. Acute toxicity ( $\mathrm{LC}_{50}$ value) for four coastal Louisiana produced water effluents (St Pé, 1990).

\begin{tabular}{|l|c|c|c|c|c|c|}
\hline & \multicolumn{2}{|c|}{24 -hour } & \multicolumn{2}{c|}{ 48-hour } & \multicolumn{2}{c|}{$96-$-hour } \\
\hline Test species & mean & range & mean & range & mean & range \\
\hline $\begin{array}{l}\text { Mysidopsis } \\
\text { bahia }\end{array}$ & $6.42 \%$ & $3.81-7.74 \%$ & $4.12 \%$ & $3.64-6.37 \%$ & $4.30 \%$ & $2.64-5.77 \%$ \\
\hline $\begin{array}{l}\text { Cyprinodon } \\
\text { variegatus }\end{array}$ & $24.68 \%$ & $13.62-35.36 \%$ & $21.23 \%$ & $7.16-35.36 \%$ & $20.13 \%$ & $7.16-33.78 \%$ \\
\hline
\end{tabular}

\subsubsection{Enviro-lab (Federal Register, 1992)}

Enviro-lab, Inc. conducted acute and chronic toxicity tests on produced water from West Delta Block 52 facility (Federal Register, 1992), Plaquemines Parish, Louisiana. The $96-\mathrm{hr}$ acute lethality $\mathrm{LC}_{50}$ tests for M. bahia were $5.8 \%$ to $15.8 \%$ effluent and for $C$. variegatus were $1.5 \%$ to $8.1 \%$ effluent. Enviro-labs 7 -day chronic tests indicated $M$. bahia survival, growth and fecundity NOEC to be respectively, $2.875 \%, 1.437 \%$ and $2.875 \%$ effluent. NOEC for $C$. variegatus survival was $1.437 \%$, and the effluent and growth values were $<1.437 \%$ effluent. 


\subsection{Field Studies}

The few available in situ bioassays generally showed that toxicity is low, although there were indications that presence of biocides in the effluents increases toxicity. Field toxicity studies were done at the BGOF (Workman and Jones, 1979).

Workman and Jones (1979) conducted a three season study between the months of June 1977 and March 1978 to determine the effects of produced water discharges on fishes and macro-crustaceans of the BGOF.

In a fall field bioassay experiment (October 1977), 20 crested blennies and 15 seaweed blennies were caged beneath the discharge of a production platform, and 26 crested blennies and 16 seaweed blennies were held in a cage under a control well jacket. The exposure time was 45 hours for the production platform and 43 hours for the well jacket. No biocides were added to the effluent during this sampling period. The results were negative, there were no mortalities.

The experiment was repeated in February 1978, under normal conditions with biocides added to the effluent (Table 7-3). A combination of 40 individuals of the two species were placed in a cage under another platform and 39 blennies were place under a control well jacket, for $48 \mathrm{hrs}$. During this experiment, a few unidentified blennies were missing from both cages. At the end of the experiment 1 blenny was missing from the platform, and 5 blennies were missing from the control well-jacket (Table 7-3).

Lethal effects on these small reef fishes were exhibited only when biocide was added to the formation water. These effects appeared to be limited to the area immediately under the discharge. Habitat limitations created by the discharge also had an effect on the size and composition of the reef fishes inhabiting the discharge leg of one production platform.

Results of the field bioassay experiment indicate that the produced water discharge by itself had no apparent effect on species of blennies commonly found on the oil structures. Toxic effects strong enough to kill the blennies were observed when biocide was added to the produced water discharge. 
Table 7-3. Field bioassay in February 1978 (adapted from Workman and Jones, 1979).

\begin{tabular}{|l|l|l|l|l|l|}
\hline Exposure & & \multicolumn{2}{|c|}{$\begin{array}{c}\text { Treatment } \\
\mathbf{4 0} \text { individuals }\end{array}$} & \multicolumn{2}{c|}{$\begin{array}{c}\text { Control } \\
\mathbf{3 9} \text { individuals }\end{array}$} \\
\hline & & Dead & Alive & Dead & Alive \\
\hline $28 \mathrm{hrs} \mathrm{15} \mathrm{min}$ & Crested Blennies & 1 & 18 & N/O & N/O \\
\hline & Seaweed Blennies & 3 & 17 & N/O & N/O \\
\hline $48 \mathrm{hrs}$ & Crested Blennies & 3 & 16 & 3 & 19 \\
\hline & Seaweed Blennies & 20 & 0 & 0 & 12 \\
\hline
\end{tabular}

$\mathrm{N} / \mathrm{O}=$ not observed

\subsection{Toxicity Studies on Sediments Near Outfalls}

E.V.S. Consultants (1990) did a sediment quality triad study on a platform in the Gulf of Mexico, near Matagorda Island, Texas. Chemical enrichment of the sediment was highest at five stations within $25 \mathrm{~m}$ from the platform. Analyses of benthic infauna found subtle differences, that were not easy to distinguish, between these five stations. In contrast to the laboratory evidence of potential toxicity, field-collected data provided evidence of faunal enrichment (more taxa, higher total abundance and abundance of specific taxa) within a $25 \mathrm{~m}$ radius of the platform, attributable to either the introduction of the platform structure or a hormetic effect of the contaminant mixture in the sediment. It was suggested that the field observations were due to offsetting factors in the environment, such as principal habitat, grain size effects, and adaptation.

\subsection{Summary}

Based on available laboratory toxicity testing and field studies, several authors (Middleditch, 1984; Neff, 1987) have indicated that produced water toxicity is generally low, and in large part attributable to the presence of biocides. Studies of individual discharges have found some with relatively high toxicities (Avanti Corporation, 1993; Table 7-1). Under ambient marine conditions, toxicity of produced water in the water column, near the discharges, should not be hazardous to marine animals, especially if these creatures are mobile.

\subsection{Application to Ecological Risk Assessment for Produced Water Discharges}

Studies of the toxicity of produced water discharges can be used to assess potential effects on organisms, and the geographic location of potential toxicity in sediments. Problems with using these data include the importance of biocides in causing toxicity, and the change in toxicity that occurs with time and space. Site-specific toxicity tests are preferable to data derived from other sources. 


\section{BIOACCUMULATION OF MAJOR TOXIC COMPONENTS OF PRODUCED WATERS}

\subsection{Introduction}

The amount of contaminant that accumulates in an organism, or its organs, is used as an indicator of dose. This accumulation is expressed as bioconcentration or bioaccumulation. There is confusion in the use of these terms. USEPA (1989b) defined bioaccumulation as the uptake and retention of a contaminant by an organism. Bioconcentration is a specific case of bioaccumulation wherein the concentration of a contaminant in an organism's tissue exceeds its concentration in the medium around the organism. Bioaccumulation is also used as a description of an overall phenomenon in which bioconcentration is a contributing parameter (Franke et al., 1994).

Although it is an indicator of bioavailability, bioaccumulation is of limited use for assessing ecological risks in the real world because it is difficult to assign a detrimental effect to accumulation of a single agent, when the agent is a component of complex mixtures that organisms typically encounter in the environment.

Bioaccumulation of a contaminant is the net result of two basic processes during a specific period of exposure:

1. uptake of a contaminant into an organism; and

2. removal of a contaminant from the organism.

Direct uptake may occur by transfer of a contaminant from external contact with a medium containing the contaminant (e.g., water column or sediment). Direct uptake can also occur by exposure of internal surfaces (gills, alimentary canal) to a contaminant bearing medium. Indirect uptake may be the result of a foodchain transfer, where the contaminant is released in the body as a result of metabolic processes. Metabolism may also convert a relatively harmless xenobiotic agent into a harmful product that is retained in the body. Therefore bioaccumulation involves accumulation in organs and tissues.

Removal may be a simple process of direct elimination of an unaltered contaminant from the body to the environment. Indirect removal can take place by metabolism of contaminants, including either sequestering in structures (scales, exoskeleton) or transfer of metabolites from the body to the environment.

The most direct estimates of bioaccumulation are achieved by measurements of biotic and media specimens simultaneously obtained in the field. Although measurements on field-collected specimens are a preferred method for 
estimating site-specific bioaccumulation, they may be fiscally prohibitive (Lee, 1992). There is limited information on bioaccumulation of specific contaminants from produced waters in marine and estuarine organisms in the Gulf of Mexico. Section 8.2 summarizes the data that describe concentrations of organics, metals and radionuclides in biota near produced water discharges. Because the data are limited, a modeling approach to estimating concentrations of organics, metals and radionuclides in animals is often used. Section 8.3 summarizes the limited bioaccumulation factors (BAFs) available for organics, metals and radionuclides.

\subsection{Field Data}

"Measuring tissue residues in field-collected sediment-dwelling organisms is the most straightforward method of assessing bioaccumulation" (Lee, 1992). Aquatic areas that contain high concentrations of contaminants are associated with detrimental effects to biota (Lamberson et al., 1992). This is especially true for animals that are exposed to contaminated sediments, either directly or as a result of trophic activity.

In most field studies detrimental effects occur in a varying milieu of complex mixtures of chemicals, both carbon based and inorganic, and complex physical conditions. Therefore, any attribution of effects to a particular type of contaminant is highly uncertain. Besides expense, obtaining sufficient tissue mass to analyze a full suite of contaminants is a major problem in field sampling, especially when perturbation has already reduced the available biomass (Lee, 1992). An alternative is to place appropriate biota in the field, in adequate numbers and for an adequate duration, to reach equilibrium with their environment. The subsections below describe studies on bioaccumulation of specific contaminants in native animals, and in animals deployed in the field, that are pertinent to investigations on produced waters.

\subsubsection{Organic and Hydrocarbon Compounds}

Bioavailability of hydrocarbon compounds is directly related to solubility in aqueous media. For sediments this refers to desorption into interstitial water, with a direct relationship to sediment grain size, and an inverse relationship to total organic content of the sediment (Capuzzo, 1987). Capuzzo reviewed bioaccumulation of petroleum related hydrocarbons (many of which are associated with produced waters) and reported that the process occurs in every investigated phylogenetic group. One of the major uncertainties in measurements of hydrocarbon compounds is determination of petrogenic and pyrogenic contributions to the suite of contaminants found at a site (Boesch and Rabalais, 1989a; St. Pé, 1990). A fossil fuel pollution index (FFPI - Boehm and Farrington, 1984) is used to indicate the relative percentage of total PAHs that are derived from petroleum sources, where concentrations of alkylated 
naphthalene, phenanthrene and dibenzothiophene are high relative to the parent compounds.

Benthic crustaceans accumulate organic and hydrocarbon compounds through contact with sediments and water above the sediments, and from food. Depuration after long-term accumulation may be rapid, but considerable fractions of the uptake may persist for years in clean water (Capuzzo, 1987). in addition to species, contaminant-mixture, and site-specific variations, there are important considerations of differential uptake, concentration and retention in organs.

Bivalve mollusks are among the most frequently investigated biota in contaminated habitats, largely because of their association with sediments and the water just above the sediments. Variability in bioaccumulation depends on species-specific physiological characteristics and environmental properties. PAHs remain relatively untransformed in mollusks because of the nature of their mixed function oxidase (MFO) systems (St. Pé, 1990). Uptake of PAHs, and elimination within 24 hours after exposure to clean sea water, are relatively rapid.

Neff et al. (1976) studied turnover of four PAH compounds associated with produced waters, and suggested that rates of uptake and retention are probably related to octanol/water partition coefficients. Highly water-soluble naphthalene (a light molecular-weight fraction compound) was quickly taken up, and was released rapidly upon depuration of the clam, Rangia cuneata. Phenanthrene accumulation was the fastest, and release the slowest among the compounds. Chrysene and benzo(a)pyrene, low solubility compounds, had the slowest rates of accumulation, and the slowest rates of release. Several studies on various bivalve species have confirmed these observations, although species and sitespecific variations were observed (Capuzzo, 1987).

Oysters (Crassostrea virginica) and mussels have been used extensively in coastal and estuarine monitoring studies, including placement of indigenous animals in the field. Measurements were made by Boesch and Rabalais (1989a) on: C. virginica taken from two inshore locations associated with produced waters (Bayou Rigaud, and East Timbalier Island) and a reference site (LUMCON Port Fourchon Laboratory); and ribbed mussels (Geukensia demissa) taken from an inshore location associated with produced waters (Pass Fourchon) and a reference site (LUMCON Marine Center, Cocodrie). Results were reported for Total PAH and Total Saturated Hydrocarbons (Table 8-1), and metals (see section 8.2.2). FFPI values $(>0.5)$ indicate that the test site contaminants were petrogenic in origin, while the reference site contaminants were pyrogenic in origin (those at LUMCON Port Fourchon Laboratory possibly originating from heavy vessel traffic). 
Table 8-1. Fossil fuel pollution index (FFPI), and concentrations (ppb) of total polycyclic aromatic hydrocarbons (PAH) and total soluble hydrocarbons $(\mathrm{SH})$ in native bivalves at inshore produced water sites and reference sites* (Boesch and Rabalais, 1989a).

\begin{tabular}{|c|c|c|c|}
\hline$\frac{\text { Organism }}{\text { Location }}$ & FFPI & $\begin{array}{c}\text { Total PAH } \\
\text { (ppb) }\end{array}$ & $\begin{array}{c}\text { Total SH } \\
\text { (ppb) }\end{array}$ \\
\hline $\begin{array}{l}\text { Crassostrea virqinica } \\
\text { Bayou Rigaud } \\
\text { East Timbalier } \\
\text { LUMCON Port Fourchon* }\end{array}$ & $\begin{array}{l}0.87,0.88 \\
0.81 \\
0.24-0.48\end{array}$ & $\begin{array}{l}2200,3400 \\
3400 \\
240-2000\end{array}$ & $\begin{array}{l}330 \times 10^{3} \\
550 \times 10^{3} \\
(68-190) \times 10^{3} \\
\end{array}$ \\
\hline $\begin{array}{l}\text { Geukensia demissa } \\
\text { Pass Fourchon } \\
\text { LUMCON Cocodrie }^{\star}\end{array}$ & $\begin{array}{l}0.72,0.77 \\
0.00\end{array}$ & $\begin{array}{l}630,880 \\
15\end{array}$ & $\begin{array}{l}(120-180) \times 10^{3} \\
.33 \times 10^{3}\end{array}$ \\
\hline
\end{tabular}

" reference sites

In a bioaccumulation study, oysters were deployed at two oil platform or oilrelated locations (Bayou Rigaud and Pass Fourchon) and two reference sites (Bayou Tartellon and Bay Champagne) in coastal waters of Louisiana (Rabalais et al., 1991; Tables 8-2, 8-3). Six sites at each of the oil-related locations represented different spatial-dilutions (distance) of contaminants from produced water discharges. Mortality and lesser weight gains of oysters in the contaminated areas may be related to contamination by produced waters and duration of exposure. Measurements were made of environmental conditions, and contaminant concentrations in sediments and oysters at each site, in a 14day and a 27-day exposure period. These periods may have been insufficient to bring the animals into equilibrium with ambient conditions, but were necessitated by predation and problems with fouling-induced mortality. A previous investigation (Boesch and Rabalais, 1989a) detected total PAH concentrations in oysters native to Bayou Rigaud, an order of magnitude greater than the concentrations shown in Tables 8-2, 8-3. Total saturated hydrocarbon concentrations were more than two orders of magnitude greater. Low values after 27 days of deployment were attributed to depletion of lipid content by spawning (Boesch and Rabalais, 1989a).

St. Pé (1990) deployed oysters in three oil producing areas and one reference site in low-energy coastal waters of Louisiana (Table 8-4). The values for PAH concentrations in the study by St. Pé (1990) were expressed on a wet weight basis, in contrast to the use of concentrations in lipid by Rabalais et al. (1991). When the values are normalized for lipid content of oysters (5\% - St. Pé, 1990), the concentrations detected after 27 days exposure by Rabalais et al. (1991) are generally higher than those reported by St. Pé, (1990) after 30 days exposure (Table 8-5). Possible explanations might be differences in ambient concentrations, biological status (health) of the test organisms, and physical and chemical conditions of the test areas. 
Table 8-2. Measured concentrations (ppm, lipid) of hydrocarbons and PAHs in oysters; controls and 14-day exposures at reference sites and oil production areas (data from Rabalais et al., 1991).

\begin{tabular}{|l|l|l|l|l|}
\hline \multicolumn{1}{|c|}{ Contaminant } & \multicolumn{1}{|c|}{ Control } & \multicolumn{1}{|c|}{$\begin{array}{c}\text { Reference } \\
\text { (Two Sites) }\end{array}$} & Pass Fourchon & Bayou Rigaud \\
\hline \hline $\begin{array}{l}\text { Total Saturated } \\
\text { Hydrocarbons }\end{array}$ & 680 & 660,640 & $890-3100$ & $760-2300$ \\
\hline Total PAH & 56 & 38,39 & $170-900$ & $120-330$ \\
\hline Anthracene & trace & trace, ND & ND -1.5 & ND -trace \\
\hline Chrysene & 7.5 & 0.50, trace & $0.80-13$ & trace-0.76 \\
\hline Naphthalene & 0.40 & $0.50,0.40$ & $0.20-0.90$ & trace-0.34 \\
\hline Fluoranthene & 1.8 & $1.6,1.2$ & $2.5-19$ & $1.1-2.0$ \\
\hline Fluorene & 0.40 & 0.30, trace & $0.70-2.4$ & ND -0.60 \\
\hline Phenanthrene & 0.80 & $0.40,0.40$ & $1.2-8.0$ & $0.71-1.8$ \\
\hline Pyrene & 1.9 & $1.2,0.90$ & $2.1-14$ & $0.76-1.7$ \\
\hline
\end{tabular}

${ }^{1}$ Range for six sample sites

Table 8-3. Measured concentrations (ppm, lipid) of hydrocarbons and PAHs in oysters; controls and 27-day exposures at reference sites and oil production areas (data from Rabalais et al., 1991).

\begin{tabular}{|l|l|l|l|l|}
\hline \multicolumn{1}{|c|}{ Contaminant } & \multicolumn{1}{c|}{ Control } & \multicolumn{1}{|c|}{ Reference } & Pass Fourchon & Bayou Rigaud \\
\hline $\begin{array}{l}\text { Total saturated } \\
\text { Hydrocarbons }\end{array}$ & 530 & 1100,500 & $1100-2000$ & $980-2000$ \\
\hline Total PAH & 6.8 & 57,24 & $110-480$ & $36-170$ \\
\hline Anthracene & ND & ND, ND & ND -0.47 & ND \\
\hline Chrysene & trace & 0.78, trace & $0.92-5.2$ & trace-0.57 \\
\hline Naphthalene & trace & trace, trace & trace-0.50 & trace-0.29 \\
\hline Fluoranthene & 0.55 & $2.1,0.84$ & $1.9-7.4$ & $0.75-0.98$ \\
\hline Fluorene & ND & ND, ND & $0.32-1.3$ & ND -trace \\
\hline Phenanthrene & 0.20 & trace, trace & $0.41-2.3$ & trace-0.94 \\
\hline Pyrene & 0.46 & $1.5,0.63$ & $1.7-6.0$ & $0.48-0.83$ \\
\hline
\end{tabular}

TRange for six sample sites 
Table 8-4. Measured concentrations ( $\mathrm{ppb}$, wet weight) of PAHs and volatile hydrocarbons in oysters; 30-day exposures at reference site and oil production areas (data from St. Pé, et al., 1990).

\begin{tabular}{|l|l|l|l|l|}
\hline \multicolumn{1}{|c|}{ Contaminant } & \multicolumn{1}{c|}{$\begin{array}{c}\text { (Reference) } \\
\text { Caillou Lake }\end{array}$} & \multicolumn{1}{c|}{ Lirette } & Bully Camp & $\begin{array}{c}\text { Lake } \\
\text { Washington }\end{array}$ \\
\hline Total PAH & trace & 22 & 130 & 280 \\
\hline Anthracene & ND & ND & ND & ND \\
\hline Chrysene & ND & ND & trace & 72 \\
\hline Naphthalene & ND & ND & ND & ND \\
\hline Fluoranthene & trace & trace & 41 & 37 \\
\hline Fluorene & ND & ND & ND & ND \\
\hline Phenanthrene & ND & trace & 28 & 66 \\
\hline Pyrene & trace & 22 & 61 & 46 \\
\hline Total Volatiles & ND & 372 & 17 & 3 \\
\hline Benzene & ND & 66 & 7 & ND \\
\hline Toluene & ND & 220 & 9 & 1 \\
\hline Ethyl Benzene & ND & 86 & 1 & 1 \\
\hline & & & & \\
\hline
\end{tabular}

Table 8-5. Comparison of ranges of concentrations of PAH (ppb, wet weight) 1 from two investigations of produced waters, by deployment of oysters, Crassostrea virginica, in Louisiana coastal waters.

\begin{tabular}{|c|c|c|c|c|c|}
\hline \multirow[b]{2}{*}{ Contaminant } & \multicolumn{3}{|c|}{ (Rabalais et al., 1991) } & \multicolumn{2}{|c|}{ (St. Pé et al., 1990) 3} \\
\hline & Control & Reference & Test Sites & Reference & Test Sites \\
\hline Total PAH & 340 & 2850,1215 & $1800-2400$ & trace & $22-280$ \\
\hline Anthracene & ND & ND & ND.-20 & ND & ND \\
\hline Chrysene & trace & 390 , trace & trace-260 & ND & trace-72 \\
\hline Naphthalene & trace & trace & trace-25 & ND & ND \\
\hline Fluoranthene & 27.5 & 105,42 & $38-370$ & trace & trace-41 \\
\hline Fluorene & ND & ND & ND -65 & ND & $\mathrm{ND}$ \\
\hline Phenanthrene & 10 & trace & trace-120 & ND & trace-66 \\
\hline Pyrene & 23 & 75,32 & $24-300$ & trace & $22-61$ \\
\hline
\end{tabular}

Data of Rabalais et al. (1991) multiplied by $20 \times 10^{3}$.

2 Two reference and 12 test sites.

3 One reference and 3 test sites.

Presley, Boothe and Brooks (1988) summarize a number of field studies performed for platforms in the Gulf of Mexico. High molecular weight hydrocarbons have been found in association with production platforms and coastal produced water discharge sites.

At the Buccanear Gas and Oil Field petroleum hydrocarbons were found in concentrations as high as $4 \mathrm{ppm}$ in the barnacle Balanus tintinnabulum collected from the platform, and as high as $16 \mathrm{ppm}$ in barnacles collected from an adjacent flame stack (Middleditch, 1984). Table 8-6 summarizes concentrations of alkanes in biota collected near the platform. 
Table 8-6. Mean concentrations of alkanes in biota sampled at the Buccanear Oil and Gas Field (data from Middleditch, 1984).

\begin{tabular}{|l|l|l|l|}
\hline \multicolumn{1}{|c|}{ Species } & \multicolumn{3}{c|}{ mean alkane concentration } \\
& \multicolumn{3}{|c|}{ (ppm) } \\
\hline & muscle & liver & whole \\
\hline crested blenny (Hypleurochilus geminatus) & & & 6.8 \\
\hline sheepshead (Archosargus probatocephalus) & 4.6 & 6.1 & \\
\hline spadefish (Chaetodipterus faber) & 0.6 & 2.0 & \\
\hline red snapper (Lutjanus campechanus) & 1.1 & 1.3 & \\
\hline brown shrimp (Penaeus aztecus) & & & 2.5 (maximum) \\
\hline & & & \\
\hline
\end{tabular}

\subsubsection{Metals}

Tables 8-7, and 8-8 demonstrate concentrations of metals found in oysters, $C$. virginica, deployed to study produced water contamination of estuarine waters on the coast of Louisiana (Rabalais, et al., 1991), as described in the previous section. Data from a previous study (Boesch and Rabalais, 1989a) suggest problems with the use of deployed animals, as opposed to measurements taken from native animals. Rabalais et al. (1991) suggested that deployment for 14 days and 21 days was insufficient for the oysters to reach equilibrium with ambient conditions. The data also suggest that transplantation per se may produce uncharacterized stresses that interfere with the animals ability to reach equilibrium, especially when comparisons of reference and control values are done for the two durations of exposure.

Table 8-7. Measured concentrations (ppm, dry weight) of metals in oysters; controls and 14-day exposures at reference sites and oil production areas (data from Rabalais et al., 1991).

\begin{tabular}{|l|l|l|l|l|}
\hline \multicolumn{1}{|c|}{ Contaminant } & \multicolumn{1}{|c|}{ Control } & \multicolumn{1}{c|}{ Reference } & Pass Fourchon & Bayou Rigaud \\
\hline \hline Aluminum & 2600 & 4100,3900 & $3800-5700$ & $4000-6600$ \\
\hline Arsenic & 54 & 190,170 & $170-220$ & $160-500$ \\
\hline Barium & 39 & 53,400 & $20-180$ & $6.1-61$ \\
\hline Cadmium & 1.9 & $2.3,10$ & $1.6-2.6$ & $2.1-3.3$ \\
\hline Chromium & 3.8 & $6.4,5.9$ & $5.8-8.4$ & $7.0-14$ \\
\hline Copper & 47 & 59,79 & $31-93$ & $33-71$ \\
\hline Lead & 0.66 & $0.15,0.84$ & $0.32-0.63$ & $0.36-0.54$ \\
\hline Mercury & ND & $0.49,0.19$ & ND-0.5 & ND-0.77 \\
\hline Nickel & 3.9 & $4.5,4.3$ & $2.8-5.4$ & $2.8-16$ \\
\hline Vanadium & 16 & 85,85 & $84-130$ & $80-300$ \\
\hline Zinc & 1500 & 2100,3200 & $1200-3400$ & $1200-3000$ \\
\hline
\end{tabular}

${ }^{1}$ Range for six sample sites 
Table 8-8. Measured concentrations (ppm, lipid) of metals in oysters; controls and 27-day exposures at reference sites and oil production areas (data from Rabalais et al., 1991).

\begin{tabular}{|l|l|l|l|l|}
\hline \multicolumn{1}{|c|}{ Contaminant } & \multicolumn{1}{|c|}{ Control } & \multicolumn{1}{c|}{ Reference } & Pass Fourchon & Bayou Rigaud \\
\hline Aluminum & & & & \\
\hline Arsenic & ND & ND, ND & ND-1.3 $\times 10^{5}$ & ND-1.1 $\times 10^{5}$ \\
\hline Barium & 1900 & 2600,1900 & ND-1000 & ND-400 \\
\hline Cadmium & 170 & 190,250 & ND-160 & ND-170 \\
\hline Chromium & 32 & 110,69 & $1.9-69$ & $9.9-77$ \\
\hline Copper & 180 & 270,190 & ND-100 & ND-130 \\
\hline Lead & 950 & 1500,1300 & $660-1800$ & $810-2800$ \\
\hline Mercury & 35 & 44,37 & ND-25 & ND \\
\hline Nickel & 260 & 370,270 & ND-120 & ND-1300 \\
\hline Vanadium & 450 & 560,540 & ND-230 & ND-320 \\
\hline Zinc & 520 & 770,640 & ND-310 & ND-220 \\
\hline
\end{tabular}

TRange for six sample sites

Presley, Boothe and Brooks (1988) summarized results of field studies (both baseline studies and platform contamination studies) that measured trace metal concentrations in biota in the Gulf of Mexico and concluded that the data suggested no significant trace metal contamination.

Table 8-9 is an example of the range of metal concentrations found in three southeastern teleostean fish species (whole fish, liver and fillets) that are not associated with oil and gas production discharges.

Table 8-9. Concentration (ppm, dry weight) ranges ${ }^{1,2}$ in three species of finfish (whole fish, liver and fillets), captured in four South Carolina estuaries (abstracted from Matthews, 1994).

\begin{tabular}{|l|l|l|l|}
\hline Metal & $\begin{array}{l}\text { Red Drum } \\
\text { Sciaenops ocellatus }\end{array}$ & $\begin{array}{l}\text { Flounder } \\
\text { Paralichthys lethostigma }\end{array}$ & $\begin{array}{l}\text { Seatrout } \\
\text { Cynoscion nebulosus }\end{array}$ \\
\hline Arsenic & ND -9.56 & ND -22.5 & ND -13.3 \\
\hline Cadmium & ND -0.42 & ND -0.78 & ND -0.50 \\
\hline Chromium & ND -1.68 & ND -2.28 & ND -3.46 \\
\hline Copper & ND -52.9 & ND -22.2 & ND -19.0 \\
\hline Lead & ND -9.68 & ND -5.78 & ND -3.65 \\
\hline Mercury & ND -96 & ND -743 & ND -687 \\
\hline Nickel & ND -2.85 & ND -12.6 & ND -8.21 \\
\hline
\end{tabular}

TMercury in $\mathrm{ppb}$

$2_{\mathrm{ND}}=<0.90 \mathrm{ppb}(\mathrm{Hg}),<0.010 \mathrm{ppm}$ (As and $\left.\mathrm{Cd}\right),<0.040 \mathrm{ppm}(\mathrm{Cu}),<0.050 \mathrm{ppm}(\mathrm{Pb})$, $0.060 \mathrm{ppm}(\mathrm{Cr}$ and $\mathrm{Ni})$ 


\subsubsection{Radionuclides}

Field studies of radium in organisms near produced water discharges include measurements of radium concentrations in: native animals collected near offshore platforms, native animals collected near coastal platforms, and oysters (Crassostrea virginica) deployed near platforms in field experiments.

\subsubsection{Offshore Platforms: Native Organisms}

\section{Continental Shelf Associates (1992b)}

Samples of biota from near two offshore platforms (at Eugene Island and Ship Shoal) were analyzed for radium. Samples were taken at $0,30,100,300$ and 2000 meters from the platform. Fishes were caught by hook and line fishing from the platform, and stone crabs and barnacles were taken from the legs of the platforms. The edible parts of fish and crustaceans were analyzed separately from the inedible bone, skin and exoskeleton. The edible parts of mollusks were analyzed for radium.

Table 8-10 gives the measured radium concentrations in the edible portions of organisms sampled at the Eugene Island platform. Table 8-11 gives the measured concentrations of radium in organisms at Ship Shoal. Barnacles and stone crabs were also taken from the platforms and analyzed for radium. More detailed data and information are given in Continental Shelf Associates (1992b).

Table 8-10. Radium concentrations measured in organisms near the Eugene Island platform.

\begin{tabular}{|c|c|c|c|c|}
\hline \multirow{2}{*}{$\begin{array}{l}\text { Distance } \\
\text { (meters) }\end{array}$} & \multicolumn{2}{|c|}{ FISH } & \multicolumn{2}{|c|}{ CRABS } \\
\hline & ${ }^{226} \mathrm{Ra}(\mathrm{pCi} / \mathrm{g})$ & ${ }^{228} \mathrm{Ra}(\mathrm{pCi} / \mathrm{g})$ & ${ }^{226} \mathrm{Ra}(\mathrm{pCi} / \mathrm{g})$ & ${ }^{228} \mathrm{Ra}(\mathrm{pCi} / \mathrm{g})$ \\
\hline & & & & \\
\hline $0^{1,2}$ & ND & ND & $<0.42$ & ND \\
\hline $50^{1,2}$ & $<0.05$ & ND & ND & $<1.64$ \\
\hline $100^{1,2}$ & $<0.31$ & $<1.45$ & $<0.51$ & 4.12 \\
\hline $300^{1,2}$ & ND & ND & ND & ND \\
\hline $2000^{1,2}$ & $<0.03$ & $<0.37$ & ND & $<3.54$ \\
\hline platform ${ }^{3}$ & ND & $<0.77$ & & \\
\hline platform 4 & ND & $<0.69$ & & \\
\hline $\begin{array}{l}1 \text { fillet, Arius } \\
2 \text { edible part } \\
3 \text { fillet, sheep } \\
4 \text { fillet, red si }\end{array}$ & a, & narginata & $\begin{array}{l}\text { atform } \\
\text { atform }\end{array}$ & \\
\hline
\end{tabular}


Table 8-11. Radium concentrations measured in organisms sampled near the Ship Shoal platform.

\begin{tabular}{|c|c|c|c|c|}
\hline Distance & & $\mathrm{SH}$ & & BS \\
\hline & ${ }^{226} \mathrm{Ra}(\mathrm{pCi} / \mathrm{g})$ & ${ }^{228} \mathrm{Ra}(\mathrm{pCi} / \mathrm{g})$ & ${ }^{226} \mathrm{Ra}(\mathrm{pCi} / \mathrm{g})$ & ${ }^{228} \mathrm{Ra}(\mathrm{pCi} / \mathrm{g})$ \\
\hline $0^{1,2}$ & ND & ND & $<0.05$ & $<1.41$ \\
\hline $50^{1,2}$ & $<0.51$ & ND & 0.16 & 3.51 \\
\hline $100^{1,2}$ & ND & 0.93 & 0.07 & 0.60 \\
\hline $300^{1,2}$ & $<0.54$ & 1.78 & 0.18 & 1.96 \\
\hline $2000^{1,2}$ & ND & ND & $<0.45$ & ND \\
\hline platform ${ }^{3}$ & ND & 0.07 & & \\
\hline platform ${ }^{4}$ & ND & ND & & \\
\hline $\begin{array}{l}1 \text { fillet, Arius } \\
2 \text { edible parts } \\
3 \text { fillet, red sr } \\
4 \text { fillet, bluefi }\end{array}$ & 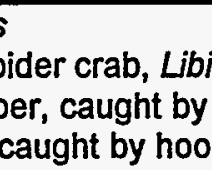 & $\begin{array}{l}\text { nata } \\
\text { ine fro }\end{array}$ & $\begin{array}{l}\text { olatform } \\
\text { orm }\end{array}$ & \\
\hline
\end{tabular}

\section{Steimle \& Associates (1992)}

This study included water, sediment and organism samples taken on and near an offshore platform (South Timbalier). Organisms were taken from the platform legs at depths of 10 to 40 meters below the water surface. Table 8-12 gives the concentrations of radium measured in fishes, crabs and mollusks taken on or near the South Timbalier platform. More detailed data and information are presented in Steimle \& Associates (1992), including concentrations measured in barnacles.

\subsubsection{Coastal Platforms: Native Organisms and Deployed Oysters}

\section{Continental Shelf Associates (1991): Native Organisms}

Data collected included ${ }^{226} \mathrm{Ra}$ and ${ }^{228} \mathrm{Ra}$ concentrations in water, sediment, fishes, shellfish and crustaceans at three coastal produced water outfalls and three background stations in Louisiana (Continental Shelf Associates, 1991). The three outfalls were located in canals along the Louisiana coast: English Bay, Golden Meadow and Avery Island. 
Table 8-12. Radium concentrations measured in organisms sampled from the legs of the South Timbalier platform.

\begin{tabular}{|l|l|l|l|l|l|}
\hline \multicolumn{2}{|c|}{ FISHES $^{1}$} & \multicolumn{2}{c|}{ CRUSTACEANS $^{2}$} & \multicolumn{2}{c|}{ MOLLUSKS } \\
\hline${ }^{226} \mathrm{Ra}$ & ${ }^{226} \mathrm{Ra}$ & $\mathrm{Ra}$ & ${ }^{228} \mathrm{Ra}$ & ${ }^{226} \mathrm{Ra}$ & ${ }^{228} \mathrm{Ra}$ \\
\hline (pCi/g) & (pCi/g) & (pCi/g) & (pCi/g) & $(\mathrm{pCi} / \mathrm{g})$ & $(\mathrm{pCi} / \mathrm{g})$ \\
\hline & & & & & \\
\hline ND & ND & 0.1 & $\mathrm{ND}$ & $0.1^{3}$ & $<0.8^{3}$ \\
\hline ND & 2.7 & 0.1 & ND & $0.1^{4}$ & $1.9^{4}$ \\
\hline ND & 2.1 & 0.1 & $<0.2$ & $0.2^{5}$ & $<0.8^{5}$ \\
\hline ND & ND & ND & $<0.2$ & & \\
\hline ND & ND & ND & ND & & \\
\hline ND & ND & 0.2 & 1.5 & & \\
\hline & & ND & ND & & \\
\hline & & 0.1 & $<0.8$ & & \\
\hline & & 0.1 & $<0.9$ & & \\
\hline & & 1.3 & $<0.9$ & & \\
\hline & & ND & 2.0 & & \\
\hline
\end{tabular}

${ }^{1}$ whole crested blenny, Hypleurochilus geminatus

2 whole stone crab, Menippe mercenaria

3 edible part, bicolor purse oyster, Isogomon bicolor

4 edible part, transverse ark clam, Anadara transversa

5 edible part, scissor datemussel, Lithophaga aristata

ND: not detected

" $<$ : : detected at a concentration less than the quantitation limit

Radium concentrations were measured in water and sediment at stations located 25 and 50 feet from the outfalls, in three directions (the outfalls were located along one side of a canal). Biological samples were taken within 50 feet of the discharge point. All mollusk samples were oyster (Crassostrea virginica), and all fish samples were seatrout (Cynoscion sp.). Crustaceans sampled at Golden Meadow were crabs (Callinectes sp.) and at English Bay and Avery Island 3 were shrimp (Penaeus sp.). Oysters were removed from the shell before analysis. Fish and crustacean samples were whole-body samples, including bone, skin and exoskeleton. Table 8-13 gives the concentration data for ${ }^{226} \mathrm{Ra}$ and ${ }^{228} \mathrm{Ra}$ at the three sites and the six background reference stations.

\section{Steimle \& Associates (1992): Native Organisms}

Steimle \& Associates (1992) measured the concentration of ${ }^{226} \mathrm{Ra},{ }^{228} \mathrm{Ra}$ and ${ }^{210} \mathrm{~Pb}$ in a study of two coastal produced water discharges. The Golden Meadow site is located on a canal, and the Quarantine Bay site is an open bay discharge. Tissue samples were collected using commercial crab traps at reference stations and at stations 50 meters from the discharge. Biota sampled at Golden Meadow site were all blue crab (Callinectes sapidus, soft and hard tissue analyzed separately). At the Quarantine Bay site, samples of the blue crab (Callinectes sapidus) and hardhead catfish (Arius felis) were analyzed for radionuclides (soft 
and hard tissue analyzed separately). Tables $8-14$ and 8-15 summarize the data for these two sites.

\section{Rabalais et al., (1991): Deployed Oysters}

Rabalais et al. (1991) measured accumulated total radium $\left({ }^{226} \mathrm{Ra}+{ }^{228} \mathrm{Ra}\right)$ in oysters (Crassostrea virginica) deployed for two time periods (April and May 1990) near outer continental shelf (OCS) discharges located in coastal Louisiana canals (Pass Fourchon, Bayou Rigaud). No radium was detected in control animals $(<0.2,2.2) \mathrm{pCi} / \mathrm{g}$. At Pass Fourchon, total radium exceeded detection limits at stations located at the discharge point $(4.3,2.2 ; 2.1,2.2 \mathrm{pCi} / \mathrm{l})$ and $200 \mathrm{~m}$ from the discharge $(1.1,2.2 ;<0.2,2.2 \mathrm{pCi} / \mathrm{l})$. No radium was detected in oysters located further from the discharges. At Bayou Rigaud radium above the detection limit was measured only at one station located within about 200 meters from one of the two discharge points during the April deployment.

\section{St Pé (1990): Deployed Oysters}

St. Pé (1990) deployed oysters (Crassostrea virginica) at three sites in a study of produced water impacts in low-energy coastal environments in Louisiana. Oysters placed at two of the study sites, and the control site did not accumulate ${ }^{226} \mathrm{Ra}$ above detection limits $(0.09-0.17 \mathrm{pCi} / \mathrm{g})$. At the Lirette Field site, deployed oysters had a ${ }^{226} \mathrm{Ra}$ concentration of $3.1 \mathrm{pCi} / \mathrm{g}$.

Table 8-13. Radium concentrations measured in organisms sampled in study of coastal produced water discharges (Continental Shelf Associates, 1991).

\begin{tabular}{|l|l|l|l|l|l|l|}
\hline STATION & \multicolumn{2}{|c|}{ FISHES $^{2}$} & \multicolumn{2}{c|}{ MOLLUSKS $^{2}$} & \multicolumn{2}{c|}{ CRUSTACEANS $^{32}$} \\
\hline & $\begin{array}{c}{ }^{226} \mathrm{Ra} \\
(\mathrm{pCi} / \mathrm{g})\end{array}$ & $\begin{array}{c}{ }^{228} \mathrm{Ra} \\
(\mathrm{pCi} / \mathrm{g})\end{array}$ & $\begin{array}{c}{ }^{226} \mathrm{Ra} \\
(\mathrm{pCi} / \mathrm{g})\end{array}$ & $\begin{array}{c}{ }^{228} \mathrm{Ra} \\
(\mathrm{pCi} / \mathrm{g})\end{array}$ & $\begin{array}{c}{ }^{226} \mathrm{Ra} \\
(\mathrm{pCi} / \mathrm{g})\end{array}$ & \begin{tabular}{c}
$\left.{ }^{22} \mathrm{RCi} / \mathrm{g}\right)$ \\
\cline { 2 - 7 }
\end{tabular} \\
\hline English Bay & 0.014 & 0.005 & 0.007 & 0.003 & 0.07 & 0.094 \\
\hline $\begin{array}{l}\text { Golden } \\
\text { Meadow }\end{array}$ & 0 & 0.022 & 0.008 & 0.011 & 0.07 & 0.025 \\
\hline $\begin{array}{l}\text { Avery } \\
\text { Island }\end{array}$ & 0.041 & 0.012 & $\mathrm{NS}$ & $\mathrm{NS}$ & 0.125 & 0.243 \\
\hline Ref 1a & $\mathrm{NS}$ & $\mathrm{NS}$ & 0.001 & 0.036 & 0.014 & 0.004 \\
\hline Ref 1b & 0.005 & 0.021 & 0.004 & 0.011 & 0.024 & 0.025 \\
\hline Ref 2a & 0.002 & 0.03 & 0.004 & 0.003 & $\mathrm{NS}$ & $\mathrm{NS}$ \\
\hline Ref 2b & 0.031 & 0.013 & 0.001 & 0.01 & 0.07 & 0.033 \\
\hline Ref 3a & 0.018 & 0.058 & $\mathrm{NS}$ & $\mathrm{NS}$ & 0.016 & 0.058 \\
\hline Ref 3b & 0.03 & 0.017 & $\mathrm{NS}$ & $\mathrm{NS}$ & 0.077 & 0.045 \\
\hline
\end{tabular}

1 seatrout (Cynoscion sp.)

2 oyster (Crassostrea virginica)

3 at English Bay and Avery Island, shrimp (Penaeus sp.); at Golden Meadow crab (Callinectes sp.)

NS = no sample 
Table 8-14. Radionuclides in blue crab at Golden Meadow.

\begin{tabular}{|l|l|l|l|}
\hline STATION & ${ }^{226} \mathrm{Ra}(\mathrm{pCi} / \mathrm{g})$ & ${ }^{228} \mathrm{Ra}(\mathrm{pCi} / \mathrm{g})$ & ${ }^{210} \mathrm{~Pb}(\mathrm{pCi} / \mathrm{g})$ \\
\hline Ref ST & $<0.02$ & $\mathrm{ND}$ & $<0.06$ \\
\hline Ref HT & 2.08 & 0.9 & $<0.22$ \\
\hline $50 \mathrm{~N} \mathrm{ST}$ & $<0.03$ & $\mathrm{ND}$ & $<0.11$ \\
\hline $50 \mathrm{NHT}$ & 1.26 & 1.1 & $<0.24$ \\
\hline $50 \mathrm{~S} \mathrm{ST}$ & 0.03 & $\mathrm{ND}$ & $\mathrm{ND}$ \\
\hline $50 \mathrm{SHT}$ & 0.81 & 0.3 & $<0.19$ \\
\hline
\end{tabular}

ST $=$ soft tissue of blue crab (Callinectes sapidus)

$H T=$ hard tissue (exoskeleton) of blue crab

ND $=$ not detected

Table 8-15. Radionuclides in blue crab and hardhead catfish at Quarantine Bay.

\begin{tabular}{|c|c|c|c|c|c|c|}
\hline STATION & \multicolumn{3}{|c|}{ Blue Crab ${ }^{T}$} & \multicolumn{3}{|c|}{ Hardhead Catfish ${ }^{2}$} \\
\hline & $\begin{array}{l}{ }^{226} \mathrm{Ra} \\
(\mathrm{pCi} / \mathrm{g})\end{array}$ & $\begin{array}{l}{ }^{228} \mathrm{Ra} \\
(\mathrm{pCi} / \mathrm{g})\end{array}$ & $\begin{array}{l}{ }^{210} \mathrm{~Pb} \\
(\mathrm{pCi} / \mathrm{g})\end{array}$ & $\begin{array}{l}{ }^{226} \mathrm{Ra} \\
(\mathrm{pCi} / \mathrm{g})\end{array}$ & $\begin{array}{l}{ }^{228} \mathrm{Ra} \\
(\mathrm{pCi} / \mathrm{g})\end{array}$ & $\begin{array}{l}2100 \mathrm{~Pb} \\
(\mathrm{pCi} / \mathrm{g})\end{array}$ \\
\hline $50 \mathrm{NW} S \mathrm{ST}$ & ND & ND & $\mathrm{ND}$ & $<007$ & ND & ND \\
\hline 50NWHT & 0.49 & $<0.7$ & ND & 0.09 & $<3.0$ & ND \\
\hline 50SE ST & NS & NS & NS & ND & ND & ND \\
\hline 50SE HT & NS & NS & NS & 0.07 & $<0.7$ & $<0.5$ \\
\hline $1000 \mathrm{NW}$ ST & ND & $<0.8$ & ND & ND & ND & ND \\
\hline $1000 \mathrm{NW} \mathrm{HT}$ & 0.3 & $<0.8$ & ND & ND & ND & ND \\
\hline 1000 NE ST & ND & ND & ND & ND & ND & ND \\
\hline 1000NE HT & 0.3 & $<0.7$ & ND & ND & ND & ND \\
\hline
\end{tabular}

1 Callinectes sapidus

2 Arius felis

ST= soft tissue

$H T=$ hard tissue, bone and exoskeleton 


\subsection{Bioaccumulation Factors}

\subsubsection{Bioaccumulation Factors for Polyaromatic Carbon Compounds}

Hellou et al. (personal communication) recently investigated bioaccumulation of polyaromatic carbon compounds (PAC) in muscle tissue from winter flounder exposed to various concentrations of crude oil in sediment during a four month period. Several levels of bioaccumulation appeared to occur independent of concentration in sediment over wide ranges. The more soluble PAH displayed higher BAF values. For example substituted naphthalenes presented the following order of BAF values from highest to lowest:

- monosaturated methyl and ethyl naphthalenes;

- dimethyl naphthalenes;

- trimethyl naphthalenes;

- C-1 tricyclic naphthalenes.

Hellou et al. (1994) observed that petroleum-derived PAC bioaccumulation begins at sediment concentrations of total PAC greater than $0.27 \mathrm{mg} / \mathrm{g}$ (dry weight), while elimination of conjugates begins at sediment concentrations greater than $10 \mathrm{mg} / \mathrm{g}$ (dry weight; Hellou and Upshall, 1994). In flounder muscle, the mean concentrations of specific PAH compounds were always greater than the median concentrations of those compounds.

Hellou (1995), Hellou and Upshall $(1994,1995)$ and Hellou et al. (1994) detected only low molecular weight PAH in flounder muscle. PAH compounds with larger numbers of rings were probably biodegraded to smaller compounds. The time for a large PAH to reach equilibrium can exceed the lifetime of the fish. A fugacity model was used to explain BAF values obtained for smaller watersoluble compounds (Hellou et al., 1995). These compounds reach equilibrium levels soonest in exposed fish, whereas the values for less soluble compounds reflect non-attainment of equilibrium, coupled with other contributory mechanisms.

The BCF for chrysene, a high molecular weight PAH was calculated to be 120 to 280. In contrast, Hellou et al. (1995) cited studies that reported higher BCF values for PAH in mussels and crustaceans (organisms with low capability to transform PAHs), than for fishes.

Hellou et al. (1995) reached the following conclusions. Near equilibrium between flounder muscle and sediment (dry weight/dry weight), regardless of $\mathrm{K}_{\mathrm{ow}}$ and the concentrations of PAC in the sediment, BAF $_{\mathrm{pac}}$ is approximately 5.5. For the more soluble compounds, such as naphthalenes, the range of BAF values is 0.03 to 12. For large parental PAH (fluorene, pyrene, chrysene, and high molecular weight PAH) and less soluble PAC, which fail to reach 
equilibrium, the range is 0.1 to 0.01 . The major factor in the low BAF for larger PAC is slow uptake, possibly combined with biodegradation of the material taken up and slow release from sediments.

\subsubsection{Bioaccumulation Factors for Inorganic and Organic Chemical Toxicants}

Only limited data are available for BAFs for organic compounds and metals in saltwater organisms. BCFs available in the literature should be reviewed in the context of their relevance and appropriateness for application to a specific organism and specific circumstance. Generic values are often used in screening-models (Table 8-16) (Stenge and Peterson, 1989; Napier et al., 1980; Strenge et al., 1986), and for organics may be calculated from octanol-partition coefficients. USEPA estimated accumulation factors for selected trace metals and petroleum components in produced waters (Table 8-17; Avanti Corporation, 1993). BCFs for some contaminants are available in the USEPA AQUIRE database (Russom et al., 1991). Table 8-18 gives maximum BCFs for three taxa of interest from the AQUIRE database.

\subsubsection{Bioaccumulation Factors for Radium}

\subsubsection{Generic Bioaccumulation Factors}

Generic or average values for bioaccumulation factors (sometimes referred to as concentration factors) were suggested based on surveys of published data (Thompson et al. 1972; Cherry and Shannon 1974; IAEA 1982; IAEA 1985). Generic bioaccumulation factors are meant for use in radiological assessment models for estimating the dose to man from a number of pathways. Commonly used models contain default bioaccumulation factors for a number of radionuclides and groups of organisms. The generic factors suggested by IAEA (1982) are used by many authors and models and are given in Table 8-19. IAEA (1985) revised these estimates upward for mollusks and fish and based the recommended bioaccumulation factors on the highest values reported in the literature (Table 8-19).

Meinhold et al. (1993) described the generic BAFs in IAEA, 1982 (100 for marine fish, mollusks and crustaceans) as consistent with published ranges of BAFs. However, the published values were based on samples taken from water with relatively low levels of ${ }^{226} \mathrm{Ra}(0.00052-0.518 \mathrm{~Bq} / \mathrm{l} ; 0.014-14.0 \mathrm{pCi} / \mathrm{l})$.

The bioaccumulation factors commonly used in dose assessment studies (IAEA, 1982,1985 ) are appropriate for screening-level assessments, but may overestimate the concentrations in edible portions of marine organisms. The factors suggested by IAEA tend to be based on the highest values reported in the literature, and appear to represent conservative values for radium. 
Table 8-16. Generic bioaccumulation factors (from Strenge and Peterson, 1989).

\begin{tabular}{|l|l|l|}
\hline Contaminant & \multicolumn{2}{|c|}{ Aquatic Bioaccumulation Factors (I/kg) } \\
\hline & Finfish & Shellfish \\
\hline Metals & & \\
\hline aluminum & 10 & 63 \\
\hline arsenic & 1 & 40 \\
\hline barium & 4 & 0.2 \\
\hline cadmium & 200 & 2000 \\
\hline chromium & 20 & 2000 \\
\hline copper & 50 & 400 \\
\hline lead & 100 & 100 \\
\hline mercury & 200000 & 20000 \\
\hline nickel & 100 & 100 \\
\hline silver & 2.30 & 770 \\
\hline vanadium & 10 & 3000 \\
\hline zinc & 2000 & 1000 \\
\hline & & \\
\hline Volatile Hydrocarbons & & \\
\hline benzene & 24.1 & 3.9 \\
\hline ethylbenzene & 146 & 27.1 \\
\hline toluene & 69.9 & 12.3 \\
\hline xylene & 177 & 33.4 \\
\hline & & \\
\hline Acid Extractable & & \\
\hline Organics & & 1.12 \\
\hline phenol & 7.57 & 0.726 \\
\hline acrolein & 344 & \\
\hline & & 315 \\
\hline PAHs & & 2810 \\
\hline anthracene & 1420 & 31.6 \\
\hline benzo (a) pyrene & 23800 & 1630 \\
\hline chrysene & 10800 & \\
\hline napthalene & 168 & \\
\hline fluoranthene & 3120 & \\
\hline fluorene & 713 & \\
\hline phenanthrene & 1440 & \\
\hline pyrene & 2800 & \\
\hline & & \\
\hline & & \\
\hline & & \\
\hline & & \\
\hline
\end{tabular}


Table 8-17. Estimated bioccumulation factors for selected trace metals and petroleum components in produced waters (modified from Avanti Corporation, 1993).

\begin{tabular}{|l|l|}
\hline Contaminant & \multicolumn{1}{|c|}{$\begin{array}{c}\text { Bioaccumulation Factor } \\
\left(\text { BCF } \times 10^{-4}\right)\end{array}$} \\
\hline & \\
\hline Metals & $0.004-2$ \\
\hline antimony & $0.03-2$ \\
\hline arsenic & 0.01 \\
\hline beryllium & $0.01-10$ \\
\hline cadmium & $0.001-0.1$ \\
\hline chromium & $0.01-1$ \\
\hline copper & $0.001-0.01$ \\
\hline lead & $0.1-10$ \\
\hline mercury & $0.001-0.1$ \\
\hline nickel & 0.01 \\
\hline selenium & $0.01-0.1$ \\
\hline silver & $0.001-10$ \\
\hline thallium & $0.01-10$ \\
\hline zinc & \\
\hline & \\
\hline Organics & 0.0045 \\
\hline benzene & 0.0052 \\
\hline toluene & 0.035 \\
\hline napthalene & 0.035 \\
\hline anthracene & 0.22 \\
\hline phenanthrene & 0.1 \\
\hline benzo (a) pyrene & 0.12 \\
\hline acenaphthalene & \\
\hline & \\
\hline & \\
\hline
\end{tabular}


Table 8-18. Maximum BCFs from USEPA AQUIRE database for exposure in salt water.

\begin{tabular}{|l|l|l|l|l|l|l|}
\hline Contaminant & Crustacea & & Mollusca & & Osteichthys & \\
\hline & BCF & Days/ & BCF & Days/ & BCF & Days/ \\
\hline & & Life Stage & & Life Stage & & Life Stage \\
\hline Metals & & & & & & \\
\hline Cadmium & & & 5000 & $\begin{array}{l}140 / \mathrm{male} \\
6-7 \mathrm{~cm}\end{array}$ & 10.5 & $14 / 30 \mathrm{~g}$ \\
\hline Chromium & & & 20 & NR/NR & & \\
\hline Lead & & & & & 12 & $14 / 200 \mathrm{~g}$ \\
\hline Mercury & & & 20 & NR/NR & & \\
\hline Zincr & & & 6750 & 14/NR & & \\
\hline & 300 & 9/NR & 1200 & 9/NR & 200 & $9 / \mathrm{NR}$ \\
\hline PAHs & & & & & & \\
\hline Benzo[a]pyrene & & & & & & \\
\hline Naphthalene & 325 & $8 / \mathrm{NR}$ & 62 & $3 / 10 \mathrm{mo}$ & 1158 & $4 / 3.35 \mathrm{~g}$ \\
\hline Fluoranthene & 310 & $4 / \mathrm{NR}$ & 5920 & $4 / \mathrm{NR}$ & & \\
\hline Phenanthrene & 400 & $4 / \mathrm{NR}$ & 1280 & $4 / \mathrm{NR}$ & & \\
\hline Pyrene & 500 & $4 / \mathrm{NR}$ & 4430 & $4 / \mathrm{NR}$ & & \\
\hline & & & & & & \\
\hline Volatile HCs & & & & & & \\
\hline Benzene & & & & & 84502 & \\
\hline & & & & & & \\
\hline Acid Extractables & & & & & & \\
\hline Phenol & 8.75 & $4 / \mathrm{NR}$ & & & & \\
\hline
\end{tabular}

NR $=$ not recorded

Table 8-19. IAEA default bioaccumulation factors for radium.

\begin{tabular}{|l|l|l|}
\hline Organisms & IAEA (1982) & IAEA (1985) \\
\hline & & \\
\hline Fish & 100 & 500 \\
\hline Mollusks & 100 & 500 \\
\hline Crustaceans & 100 & 500 \\
\hline
\end{tabular}

\subsubsection{Bioaccumulation Factors for the Gulf of Mexico}

Meinhold and Hamilton (1991) derived radium concentration factors for fish, mollusks and crustaceans from data collected by Continental Shelf Associates (1991) in a study of coastal produced water discharges (see section 8.2.3.2). 
BAFs calculated from this data set cover a wide range (Table 8-20).

Bioaccumulation factors ranged from 3 to 100 for whole fishes, from 2 to 240 for the soft parts of mollusks and from 4 to 170 for whole crustaceans:

Based on the published data and an independent analysis of data collected in the 1991 Continental Shelf Associates study, it can be concluded that BAFs for radium in whole fishes, soft parts of mollusks, and whole crustaceans are affected by the concentration of radium in the water. The BAFs in Table 8-20 calculated for the concentrations in water at reference sites $\left({ }^{226} \mathrm{Ra}, 0.2\right.$ to 0.7 $\mathrm{pCi} / ;{ }^{228} \mathrm{Ra}, 0.0$ to $\left.10.3 \mathrm{pCi} / \mathrm{l}\right)$ in the Continental Shelf Associates (1991) study were smaller, in general, than the IAEA BAFs (100) for salt water fish, mollusks and crustaceans. The BAFs calculated from the 1991 Continental Shelf Associates data suggest that the generic IAEA BAFs may be over-estimates at the relatively high concentrations encountered in produced water discharges.

A BAF for radium may be expected to be a function of the element as a chemical entity. Meinhold et al. (1991) estimated BAFs for ${ }^{226} \mathrm{Ra}$ and ${ }^{228} \mathrm{Ra}$ separately. There was disparity between the BAFs for the two isotopes at each site. This may have contributed to the overestimates because measurements were made by radiodetection. Measurements for ${ }^{228}$ Ra were less sensitive (detection limits were higher), and the two isotopes are not in equilibrium with each other in produced water.

\subsection{Application to Ecological Risk Assessment for Produced Water Discharges}

Data describing the bioaccumulation of produced water components can be used to formulate the problem, identify contaminants of potential concern and assess exposure. They can also be used to assess effects, although data relating body burdens to effects are limited. The BAF approach is commonly used in both human health and ecological risk assessments, but its reliability may be questionable. 
Table 8-20. Calculated radium bioaccumulation factors for organisms sampled in the Continental Shelf Associates (1991) study.

\begin{tabular}{|c|c|c|c|c|c|c|c|}
\hline \multirow[t]{3}{*}{ Station } & \multirow{3}{*}{$\begin{array}{l}\text { Conc. at } 50 \\
\text { feet }^{1} \text { (pCi/l) } \\
{ }^{226} \mathrm{Ra}{ }^{228} \mathrm{Ra}\end{array}$} & \multicolumn{6}{|c|}{ Bioaccumulation factors } \\
\hline & & \multicolumn{2}{|c|}{ Fish } & \multicolumn{2}{|c|}{ Mollusks } & \multicolumn{2}{|c|}{ Crustaceans } \\
\hline & & ${ }^{226} \mathrm{Ra}$ & ${ }^{228} \mathrm{Ra}$ & ${ }^{226} \mathrm{Ra}$ & ${ }^{228} \mathrm{Ra}$ & ${ }^{226} \mathrm{Ra}$ & ${ }^{228} \mathrm{Ra}$ \\
\hline & & $(\mathrm{pCi} / \mathrm{g})$ & $(\mathrm{pCi} / \mathrm{g})$ & $(\mathrm{pCi} / \mathrm{g})$ & $(\mathrm{pCi} / \mathrm{g})$ & $(\mathrm{pCi} / \mathrm{g})$ & $(\mathrm{pCi} / \mathrm{g})$ \\
\hline & & & & & & & \\
\hline $\begin{array}{l}\text { English } \\
\text { Bay }\end{array}$ & $0.43 / 0.93$ & 32.6 & 5.4 & 16.3 & 3.2 & 169.8 & 101.1 \\
\hline $\begin{array}{l}\text { Golden } \\
\text { Meadow }\end{array}$ & $0.52 / 0.22$ & NC & 100 & 15.4 & 50 & 130 & 113.6 \\
\hline $\begin{array}{l}\text { Avery } \\
\text { Island }\end{array}$ & $0.92 / 4.0$ & 45.6 & 3.0 & NDA & NDA & 138.9 & 60.8 \\
\hline $\operatorname{Ref} 1 \mathrm{a}$ & $0.25 / 0.15$ & NDA & NDA & 4.0 & 240 & 56.0 & 26.7 \\
\hline Ref 1b & $0.2 / 0$ & 25.0 & NC & 20.0 & NC & 120.0 & NC \\
\hline Ref 2a & $0.7 / 0$ & 2.9 & NC & 5.7 & NC & NDA & NDA \\
\hline Ref $2 b$ & $0.5 / 0$ & 62.0 & NC & 2.0 & NC & 138.0 & NC \\
\hline $\operatorname{Ref} 3 a$ & $0.7 / 3.3$ & 25.7 & 17.6 & $\overline{\mathrm{NDA}}$ & $\overline{N D A}$ & 22.9 & 17.6 \\
\hline Ref $3 b$ & $0.7 / 10.3$ & 42.9 & 1.7 & NDA & NDA & 110.0 & 4.4 \\
\hline
\end{tabular}

NDA: no data

NC: bioaccumulation factor not calculated because water or animal concentration was reported in Continental Shelf Associates (1991) as 0

1 average of measured concentration at three stations, each 50 feet from discharge 


\section{TOXICITY OF MAJOR INDIVIDUAL CHEMICAL COMPONENTS}

\subsection{Introduction}

The toxicity of produced water effluents is the most important information to assess risks to aquatic animals that live close to produced water discharge points (i.e. on the platforms as part of the fouling community or within several meters). If this information is available, assessing risks from individual components in the water is not necessary, and could miss combined effects of individual contaminants. The discharge changes character with increasing distance from the source, and various components react and partition differently in the environment. At some point, however, an assessment must rely on data that describe the effects of individual chemical components of produced water discharges. The same types of data are needed in an assessment of the risks to animals exposed to contaminants in sediment

A large amount of laboratory data are available to describe the toxicity of individual contaminants on various saltwater organisms. The task in an ecological risk assessment is to identify those data relevant to the identified endpoint(s) of concern, and to make some judgment about the validity and comparability of laboratory toxicity tests.

A good place to start in developing the toxicity data needed in an analysis are the USEPA water quality criteria developed to protect saltwater animals as well as other values (USEPA, 1986; see section 9.2.1). Additional data are available in the documents that support these criteria, in the open literature, and in electronic data bases such as the USEPA ACQUIRE data base (section 9.2.2). Another important concern in terms of potential impacts from produced water are effects on animals living on or in the sediment. There are limited data available to describe toxicities to these organisms, but sediment quality criteria have been derived for some contaminants and these are reviewed in section 9.3. Limited data are also available to suggest a relationship between exposure to contaminants in water and sediment and genotoxic and histopathologic effects in fish (section 9.4).

\subsection{Toxicity of Chemicals in Water}

\subsubsection{USEPA Water Quality Criteria}

The Clean Water Act requires the USEPA to publish and update ambient water quality criteria. "These criteria are to accurately reflect the latest scientific knowledge (a) on the kind and extent of all identifiable effects on health and welfare including, but not limited to, plankton, fish, shellfish, wildlife, plant life, shoreline, beaches, aesthetics, and recreation which may be expected from the presence of pollutants in any body of water including ground water; (b) on the 
concentration and dispersal of pollutants or their byproducts, through biological, physical and chemical processes; and (c) on the effects of pollutants on biological community diversity, productivity and stability, including information on the factors affecting rates of eutrophication and organic and inorganic sedimentation for varying types of receiving waters" (USEPA, 1986).

\section{Water Quality Criteria Guidelines}

Procedures for developing criteria are presented in (USEPA, 1986). Current water quality criteria for important produced water components were developed using the 1980 and 1986 guidelines. These two sets of guidelines are summarized below.

\section{Guidelines (USEPA, 1986, Appendix A)}

The 1985 guidelines define acceptable tests, numbers of species and families, acute-chronic ratios, and bioaccumulation factors needed to derive a water quality criterion. "The guidelines indicate that if enough acceptable data on acute toxicity to aquatic animals are available, they are used to estimate the highest 1 -hour average concentration that should not result in unacceptable effects on aquatic organisms and their uses. If justified, this concentration is made a function of a water quality characteristic such as $\mathrm{pH}$, hardness or alkalinity. Similarly, data on the chronic toxicity of the material to aquatic animals are used to estimate the highest 4-day average concentration that should not cause unacceptable toxicity during a long-term period" (USEPA, 1986, Appendix A).

The "Final Acute Value" is an estimate of the concentration corresponding to a cumulative probability of 0.05 in the acute toxicity values for the genera with which acceptable acute toxicity tests have been conducted. If a commercially or recreationally important species has a "Mean Acute Value" lower than this "Final Acute Value", then that value replaces the "Final Acute Value" to protect this species. The "Final Chronic Value" may be calculated in the same manner as the "Final Acute Value", or by dividing the "Final Acute Value" by the "Final Acute-Chronic Ratio". Acute-chronic ratios relate the acute and chronic toxicities of a contaminant to aquatic organisms. A "Final Plant Value" is derived to describe the toxicity of the material to plants. A "Final Residue Value" is derived based on bioconcentration or bioaccumulation factors and FDA action levels (to protect humans) and acceptable dietary intakes for wildlife.

The Criterion is derived from these values as follows: 
- The criterion maximum concentration (acute criterion, the highest 1-hour average concentration that should not result in unacceptable effects on aquatic organisms), is equal to $1 / 2$ the "Final Acute Value".

- The criterion continuous concentration (chronic criterion, the highest 4-day average concentration that should not cause unacceptable toxicity during a long-term period) is equal to the lowest of the "Final Chronic Value", "Final Plant Value" and "Final Residue Value", unless other data show that a lower value should be used (e.g., behavioral studies, flavor impairment, delayed or cumulative toxicity).

1980 Guidelines (USEPA, 1986, Appendix B)

"Minimum data requirements are identified in four areas; acute toxicity to animals (eight data points), chronic toxicity to animals (three data points), toxicity to plants, and residues". "A "Final Acute Value" is derived from data on acute toxicity to fish and invertebrates". "By taking into account the number and relative sensitivities of the tested species, the "Final Acute Value" (quotes added) is designed to protect most, but not necessarily all, of the tested and untested species" (USEPA, 1986, Appendix B). A "Final chronic Value" can be calculated directly from chronic toxicity test data, or an acute-chronic ratio derived and applied to the "Final Acute Value". "A "Final Plant Value" is obtained by selecting the lowest plant toxicity value" (USEPA, 1986, Appendix B). A "Final Residue Value" is derived based on bioconcentration factors and FDA action levels (to protect humans) and acceptable dietary intakes for wildlife.

The Criterion is derived from these values as follows:

- The maximum concentration (acute criterion) is equal to the "Final Acute Value".

- The 24-hour average value (chronic criterion) is equal to the lowest of the "Final Chronic Value", "Final Plant Value" and "Final Residue Value".

\section{Specific Water Quality Criteria}

Current and proposed water quality criteria for important components of produced water are listed in Table 9-1. The following summaries are modified from USEPA (1985; except where noted) and reflect the data available at the time each criterion was developed $(1985,1980,1976)$. Summaries of criteria developed under the 1985 guidelines are more detailed than those developed under earlier guidelines. More details are available in the criteria documents available for each contaminant. 
TABLE 9-1. USEPA (USEPA, 1985 and proposed) and LDEQ Water Quality Criteria.

\begin{tabular}{|c|c|c|c|c|}
\hline \multirow[t]{2}{*}{ Contaminant } & \multicolumn{2}{|c|}{ USEPA } & \multicolumn{2}{|c|}{ LDEQ $^{\top}$} \\
\hline & $\begin{array}{l}\text { saltwater } \\
\text { acute } \\
\text { ( } \mu \mathrm{g} / \mathrm{l})\end{array}$ & $\begin{array}{l}\text { saltwater } \\
\text { chronic } \\
\text { ( } \mu \text { g/l) }\end{array}$ & $\begin{array}{l}\text { saltwater } \\
\text { acute } \\
(\mu \mathrm{g} / \mathrm{l})\end{array}$ & $\begin{array}{l}\text { saltwater } \\
\text { chronic } \\
\text { ( } \mu \mathrm{g} / \mathrm{l})\end{array}$ \\
\hline \multicolumn{5}{|l|}{ METALS } \\
\hline arsenic (III) & 69. & 36. & 69. & 36. \\
\hline cadmium & 43. & 9.3 & 45.62 & 10.0 \\
\hline chromium (VI) & 1,100 & 50 & 1,100 & 50 \\
\hline copper & 2.9 & - & 4.37 & 4.37 \\
\hline lead & 140 & 5.6 & 220. & 8.5 \\
\hline mercury & 2.1 & 0.025 & 2.1 & 0.025 \\
\hline silver & 7.2 & 0.92 & - & - \\
\hline zinc & 95. & 86. & 95. & 86. \\
\hline \multicolumn{5}{|l|}{ ORGANICS } \\
\hline benzene & $5,100 .^{2}$ & $700 .^{2}$ & 2,700 . & 1,370 \\
\hline ethylbenzene & $430^{2}$ & - & 8,760 & 4,380 \\
\hline toluene & $6,300 .^{2}$ & $5,000 .^{2}$ & 950 & 475 \\
\hline phenol & $5,800 .^{2}$ & - & 580. & 290. \\
\hline acrolein & $55^{1}$ & - & - & - \\
\hline \multicolumn{5}{|l|}{ PAHS } \\
\hline PAHs (generic) & $300^{2}$ & - & - & - \\
\hline fluoranthene & $40^{2}$ & $16 .^{2}$ & - & - \\
\hline napthalene & $2,350 .^{2}$ & - & - & $\overline{-}$ \\
\hline phenanthrene & $7.7^{\mathrm{P}}$ & $4.6^{P}$ & $=$ & - \\
\hline & & & & \\
\hline
\end{tabular}


Metals

Arsenic Twelve species of saltwater animals have acute values for inorganic arsenic (III) from $232 \mu \mathrm{g} / \mathrm{l}$ to $16,030 \mu \mathrm{g} / \mathrm{l}$ and the single acute-chronic ratio is 1.945. The only values available for inorganic arsenic $(V)$ are for two invertebrates and are between 2,000 and $3,000 \mu \mathrm{g} / \mathrm{l}$. Very few data are available concerning the toxicity of any form of arsenic other than inorganic arsenic (III) to saltwater aquatic life. Inorganic arsenic (V) is acutely toxic to saltwater animals at concentrations as low as $2,319 \mu \mathrm{g} / \mathrm{l}$. The saltwater acute criterion for arsenic (III) is $69 \mu \mathrm{g} / \mathrm{l}$, and the chronic criterion is $36 \mu \mathrm{g} / \mathrm{l}$. There are not enough data to derive saltwater criteria for arsenic (V), but an acute LOAEL of $2,319 \mu \mathrm{g} / \mathrm{l}$ and a chronic LOAEL of $5 \mu \mathrm{g} / \mathrm{l}$ are given (summary chart, USEPA, 1986).

Cadmium Saltwater acute values for cadmium in five fish species ranged from $577 \mu \mathrm{g} / \mathrm{l}$ in larval Atlantic silverside to $14,000 \mu \mathrm{g} / \mathrm{l}$ for juvenile mummichog. Acute values for 30 species of invertebrates ranged from $15.5 \mu \mathrm{g} / \mathrm{l}$ for a mysid to $135,000 \mu \mathrm{g} / \mathrm{l}$ for an oligochaete worm. Acute toxicity generally increases with an increase in salinity. Two life-cycle tests with Mysidopsis bahia under different test conditions resulted in similar chronic values of $8.2 \mu \mathrm{g} / \mathrm{l}$ and $7.1 \mu \mathrm{g} / \mathrm{l}$, with acute-chronic ratios of 1.9 and 15. A life-cycle test with Mysidopsis bigelowi also resulted in a chronic value of $7.1 \mu \mathrm{g} / \mathrm{l}$ and an acute-chronic ratio of 15 . Acute values appear to reflect effects of salinity and temperature, but chronic values do not. The saltwater acute criteria for cadmium is $43 \mu \mathrm{g} / \mathrm{l}$, the saltwater chronic criteria is $9.3 \mu \mathrm{g} / \mathrm{l}$.

Chromium (VI) The acute toxicity of chromium (VI) to 23 saltwater vertebrate and invertebrate species ranges from $2,000 \mu \mathrm{g} / \mathrm{l}$ for a polychaete worm and a mysid to $105,000 \mu \mathrm{g} / \mathrm{l}$ for the mud snail. Chronic values for a polychaete range from $<13$ to $36.74 \mu \mathrm{g} / \mathrm{l}$, and the chronic value for a mysid was $132 \mu \mathrm{g} / \mathrm{l}$. The acute-chronic ratios range from 15.38 to $<238.5$. The saltwater acute criteria for cadmium (VI) is $1,100 \mu \mathrm{g} / \mathrm{l}$, and the chronic criteria is $50 \mu \mathrm{g} / \mathrm{l}$. Data suggest that the acute toxicity of chromium (VI) is salinity dependent, and the 1-hour average concentration (i.e. the chronic criteria) might be underprotective at low salinities.

Copper Acute sensitivities range from $5.8 \mu \mathrm{g} / \mathrm{l}$ for the blue mussel to $600 \mu \mathrm{g} / \mathrm{l}$ for the green crab. In a chronic life-cycle test with a mysid, adverse effects were observed at $77 \mu \mathrm{g} / \mathrm{l}$ but not at $38 \mu \mathrm{g} / \mathrm{l}$, resulting in an acute-chronic ratio of 3.346. In long-term exposures, the bay scallop was killed at $5 \mu \mathrm{g} / \mathrm{l}$. The saltwater acute criterion for copper is $2.9 \mu \mathrm{g} / \mathrm{l}$. No chronic criterion was derived.

Lead Acute values are available for 13 saltwater animal species and range from $315 \mu \mathrm{g} / \mathrm{l}$ for the mummichog to $27,000 \mu \mathrm{g} / \mathrm{l}$ for the soft shell clam. In a chronic 
toxicity test conducted with a mysid, unacceptable effects were observed at 37 $\mu \mathrm{g} / \mathrm{l}$ but not at $17 \mu \mathrm{g} / \mathrm{l}$; acute-chronic ratio for this species is 124.8 . The acute saltwater criterion for lead is $140 \mu \mathrm{g} / \mathrm{l}$, and the chronic criterion is $5.6 \mu \mathrm{g} / \mathrm{l}$ (USEPA IRIS database, 1996).

Mercury Data on the acute toxicity of mercuric chloride are available for 29 genera of saltwater animals. Acute values range from $3.5 \mu \mathrm{g} / \mathrm{l}$ for a mysid to $1,678 \mu \mathrm{g} / \mathrm{l}$ for winter flounder. Fishes tend to be more resistant and mollusks and crustaceans more sensitive to the effects of mercury (II). Results of a lifecycle test with the mysid show significant effects on the time of first spawn and productivity at $1.6 \mu \mathrm{g} /$; acute-chronic ratio was 3.1. The acute saltwater criterion for mercury is $2.1 \mu \mathrm{g} / \mathrm{l}$, and the chronic criterion is $0.025 \mu \mathrm{g} / \mathrm{l}$.

Silver For saltwater life the acute crtierion is $7.2 \mu \mathrm{g} / \mathrm{l}$. The chronic criterion is $0.92 \mu \mathrm{g} / \mathrm{l}$ (USEPA IRIS database, 1996).

Zinc For saltwater life the acute crtierion is $95 \mu \mathrm{g} / \mathrm{l}$. The chronic criterion is 86 $\mu \mathrm{g} / \mathrm{l}$ (USEPA IRIS database, 1996).

\section{Organics}

Benzene The available data indicate that acute toxicity occurs at concentrations as low as $5,100 \mu \mathrm{g} / \mathrm{l}$, and would occur at lower concentrations in more sensitive species. No definitive data are available concerning the chronic toxicity of benzene, but adverse effects occur at concentrations as low as $700 \mu \mathrm{g} / \mathrm{l}$. No criteria are given, but the LOAEL for acute toxicity is given as $5,100 \mu \mathrm{g} / \mathrm{l}$, and the LOAEL for chronic toxicity is given as $700 \mu \mathrm{g} / \mathrm{l}$ (summary chart, USEPA 1986).

Ethylbenzene The available data for ethylbenzene indicate that acute toxicity to saltwater aquatic life occurs at concentrations as low as $430 \mu \mathrm{g} / \mathrm{l}$. No data are available concerning chronic toxicity. There are not enough data to justify water quality criteria, but an acute toxicity LOAEL of $430 \mu \mathrm{g} / \mathrm{l}$ is given (summary table, USEPA, 1986).

Toluene Available data for toluene indicate that acute toxicity to saltwater aquatic life occurs at concentrations as low as 6,300 $\mu \mathrm{g} / \mathrm{l}$ (LOAEL). Chronic toxicity occurs at concentrations as low as $5,000 \mu \mathrm{g} / \mathrm{l}$ (LOAEL). Acute and chronic toxicity would occur at lower concentrations in more sensitive species. Data are not adequate for a water quality criterion.

Phenol Available data indicate that acute toxicity to saltwater aquatic life occurs at concentrations as low as $5,800 \mu \mathrm{g} / \mathrm{l}$ (LOAEL) and would occur at lower concentrations in more sensitive species. Data are not adequate for a water quality criterion. No data are available concerning chronic toxicity. 
Acrolein Available data for acrolein indicate that acute toxicity to saltwater life occurs at concentrations as low as $55 \mu \mathrm{g} / \mathrm{l}$, and would occur at lower concentrations among more sensitive species than those tested. No data are available concerning chronic toxicity. Data are not adequate for a criterion, value given ( $55 \mu \mathrm{g} / \mathrm{l}$ is LOAEL).

\section{Polycyclic Aromatic Hydrocarbons (PAH)}

PAH (polycyclic or polynuclear aromatic hydrocarbons) are a class of diverse compounds formed during the incomplete combustion of organic material (USEPA, 1991). Priority pollutant PAHs found in the environment include (USEPA, 1991):

- acenaphthtylene

- anthracene

- benz(a)anthracene

- benzo(a)pyrene

- benzo(b)fluoranthene

- benzo(k)fluoranthene

- benzo((g,h,i)perylene

- chrysene
- dibenz(a,h)anthracene

- fluoranthene

- fluorene

- indeno(1,2,3-cd)pyrene

- napthalene

- phenanthrene

- pyrene

PAH (generic) Fluoranthene, napthalene and phenanthrene have their own criteria, proposed criteria or LOAELs. For other PAHS, available data indicate that acute toxicity to saltwater aquatic life occurs at concentrations as low as 300 $\mu \mathrm{g} / \mathrm{l}(\mathrm{LOAEL}$ ) and would occur at lower concentrations among more sensitive species. Data are not adequate for a water quality criterion. No data are available concerning chronic toxicity.

Fluoranthene Data for fluoranthene indicate that acute toxicity to saltwater aquatic life occurs at concentrations as low as $40 \mu \mathrm{g} / \mathrm{l}$ and chronic toxicity occurs as low as $16 \mu \mathrm{g} / \mathrm{l}$ and would occur at lower concentrations among species that are more sensitive than those tested. Values are LOAELs, not water quality criteria.

Napthalene The available data indicate that acute toxicity to saltwater aquatic life occurs at concentrations as low as 2,350 $\mu \mathrm{g} / \mathrm{l}$ (LOAEL) and would occur at lower concentrations among more sensitive species. Data are not adequate for a water quality criterion. No data are available concerning chronic toxicity.

Phenanthrene Phenanthrene has a proposed saltwater acute criterion of 7.7 $\mu \mathrm{g} / \mathrm{l}$, and a proposed chronic criterion of $4.6 \mu \mathrm{g} / \mathrm{l}$. 


\subsubsection{Available Toxicity Data}

USEPA maintains a comprehensive AQUatic toxicity REtrieval Database (AQUIRE) that is updated quarterly (Russom et al., 1991). The goal of this data base is to enhance ecological and human health risk assessment processes, by providing comprehensive access to up-to-date available information on aquatic pollutants, including: standardized nomenclature and CAS registry numbers for each chemical; test organism identification by scientific and common names; parameters such as life stage; taxonomic information; test conditions and location; exposure duration and type; water chemistry and chemical analyses; adequacy of controls; effects parameters; and references for each entry. Table 9-2 illustrates a derivation from retrieved information on toxicity $\left(L_{50}\right)$ of minimal concentrations of contaminants that may be associated with release of produced waters to the Gulf of Mexico.

\subsection{Sediment Chemical Toxicity}

\subsubsection{Background}

Sediments are heterogeneous mixtures of abiotic and biotic materials, of natural and anthropogenic origins (Power and Chapman, 1992). Sediment contents reflect movement of chemicals from the water column to the sediments and vice versa (net deposition), from overlying sediments to deeper layers, and transformations of the chemicals within the sediments. A sediment is both a sink and a source for toxic materials in the marine environment (Power and Chapman, 1992), and is an integrated measure of the changes in its chemical contents at the time of sampling.

Chemical contaminants can be found in sediment pore water and/or bound to the solids that form the substrate. Because of their intimate contact with sediments, benthic and interstitial organisms are directly exposed to contaminants by way of ingestion of sediments, or direct transfer at exposed surfaces (e.g. respiratory organs). The key to toxicity of the chemical components is bioavailability of the chemicals.

"Sediment toxicity tests provide a rapid integrated measure of the effects of a substrate and the chemicals found in it on a toxicologic representative of benthic fauna" (Lamberson, DeWitt and Swartz, 1992). These tests directly describe the interactive effects of both measured and unmeasured chemicals in fieldcollected sediment samples. The tests also account for the influence of biotic and abiotic factors in sediments. 
Table 9-2. Minimum Concentrations of Contaminants yielding $L C_{50} S$ in selected taxa of aquatic organisms in salt water. ${ }^{1}$

\begin{tabular}{|c|c|c|c|c|c|c|c|c|c|}
\hline \multirow[t]{2}{*}{ Contaminant } & \multicolumn{9}{|c|}{ Taxa } \\
\hline & Crustacea & Units & $\mathrm{DC}^{2}$ & Mollusca & Units & $\mathrm{DC}^{2}$ & Osteichthys & Units & $D C^{2}$ \\
\hline \multicolumn{10}{|l|}{ Metals } \\
\hline \multicolumn{10}{|l|}{ Aluminum } \\
\hline Arsenic & 1740 & $\mu g / l$ & 1 & & & & & & \\
\hline Beryllium & & & & & & & $>500000$ & $\mu g / l$ & 2 \\
\hline Cadmium & 224 & $\mu g / /$ & 1 & 80 & $\mu g / l$ & 2 & 19 & $\mu g / l$ & 2 \\
\hline Chromium & 2030 & $\mu g / 1$ & 1 & 11.5 & $\mu \mathrm{g} / \mathrm{l}$ & 2 & & & \\
\hline \multirow[t]{2}{*}{ Copper } & 55 & $\mu \mathrm{g} / \mathrm{l}$ & $1 ?$ & 200 & $\mu \mathrm{g} / \mathrm{l}$ & 2 & 24 & $\mu \mathrm{g} / \mathrm{l}$ & 2 \\
\hline & $3.00 \mathrm{E}-07$ & $\mu \mathrm{g} / \mathrm{l}$ & 2 & & & & & & \\
\hline Lead & 3130 & $\mu g / l$ & 1 & & & & & & \\
\hline Mercury & 10 & $\mu g / /$ & 2 & & & & 300 & $\mu g / l$ & 2 \\
\hline Nickel & 508 & $\mu \mathrm{g} / \mathrm{l}$ & 1 & & & & & & \\
\hline Silver & 249 & $\mu g / /$ & 1 & & & & 58000 & $\mu \mathrm{g} / \mathrm{l}$ & 2 \\
\hline \multicolumn{10}{|l|}{ Vanadium } \\
\hline Zinc & 499 & $\mu g / I$ & 1 & & & & 30 & $\mu g / /$ & 2 \\
\hline & & & & & & & & & \\
\hline \multicolumn{10}{|l|}{ PAHs } \\
\hline Naphthalene & 850 & $\mu \mathrm{g} / \mathrm{l}$ & 2 & 57000 & $\mu \mathrm{g} / \mathrm{l}$ & 2 & 1200 & $\mu \mathrm{g} / \mathrm{l}$ & 2 \\
\hline Fluoranthene & & & & & & & $>560000$ & $\mu g / l$ & 2 \\
\hline & & & & & & & & & \\
\hline \multicolumn{10}{|l|}{\begin{tabular}{|l|} 
Volatile HCs \\
\end{tabular}} \\
\hline \multirow[t]{2}{*}{ Benzene } & 20 & $\mu \mathrm{I} / \mathrm{l}$ & 2 & 190000 & $\mu \mathrm{g} / \mathrm{l}$ & 2 & 5.8 & $\mu \mathrm{l} / \mathrm{I}$ & 2 \\
\hline & & & & & & & 10.9 & $\mu \mathrm{l} / \mathrm{l}$ & 1 \\
\hline Ethylbenzene & 0.49 & $\mu \mathrm{l} / \mathrm{l}$ & 2 & & & & 4.3 & $\mu \mathrm{i} / \mathrm{I}$ & 2 \\
\hline Xylene & 7400 & $\mu g / l$ & 2 & 190000 & $\mu g / \mathrm{l}$ & 2 & 89000 & $\mu g / l$ & 2 \\
\hline & & & & & & & & & \\
\hline \multicolumn{10}{|l|}{ Acid Extractables } \\
\hline $\begin{array}{r}\text { Phenol } \\
\end{array}$ & 89500 & $\mu \mathrm{g} / \mathrm{l}$ & 1 & 53500 & $\mu g / l$ & 2 & 9500 & $\mu \mathrm{g} / \mathrm{l}$ & 1 \\
\hline & 5800 & $\mu \mathrm{g} / \mathrm{l}$ & 2 & & & & & & \\
\hline
\end{tabular}

'Derived from USEPA's AQUIRE data February 15, 1995 (The information does not include salts of metals, or derivatives of parent compounds, and has not been verified from the references supplied by AQUIRE).

2Data Completeness (USEPA rating): 1 = data complete; 2 = data may be adequate, but is missing an element, such as control data; 3 and $4=$ data are less than adequate, and are not used. 
By using different methods and periods of exposure, and life stages of more than one biological species, bioassays provide toxicological information on a variety of endpoints for different levels of biological organization. Acute tests usually use mortality as an endpoint, while chronic tests include sublethal endpoints, such as growth, development, reproduction and behavior. When combined with other studies they provide opportunities to determine cause and effect relationships. Tests are performed on whole sediment, suspended sediment, pore or interstitial water, and sediment extracts (e.g., aqueous and organic solvent). Unfortunately, the Gulf of Mexico is one of the geographic regions that are not represented by the species routinely used in sediment toxicity tests. Therefore toxicity bioassays are only indicators of potential toxicity, rather than predictors of ecological changes in the Gulf of Mexico.

\subsubsection{Methods for Developing Sediment Quality Criteria}

Marine environments containing high levels of (multiple) contaminants are associated with adverse effects on biota, and a potential for adverse human health effects. However, no direct causal relationship has been established between a single contaminant and a biological effect in a natural marine environment. Therefore, development of sediment quality criteria relies on prudent use of the best information available and empirical data (E.V.S. Consultants, 1990).

The two major approaches for developing sediment quality criteria are chemicalby-chemical criteria, and combinations of chemical-by-chemical criteria with chemical mixture criteria. Methods for developing these criteria were evaluated and described (E.V.S. Consultants, 1990; Long and Morgan, 1990; Long et al., 1995):

- Background Sediment Chemistry

- Water Quality Criteria

- Sediment/water equilibrium partitioning (SEP)

- Sediment Bioassay

- Screening level concentration

- Apparent effects threshold (AET)

- Sediment Quality Triad (triad)

This section briefly describes the reviews of the favored choices of methods to be used for the two approaches.

SEP is favored for chemical-by-chemical criteria, and is the basis for USEPA's criteria (Long and Morgan, 1995; USEPA, 1992). This method is not used for complex mixtures. SEP combines a theoretical combination of equilibrium partitioning, as used in the water quality criteria method, with a correction for the 
effects of organic carbon and, in some cases, acid volatile sulfides. The only field measurements needed are analyses of contaminant concentrations in sediments and inorganic content in those sediments. It takes advantage of methods for comparing sediment interstitial water concentrations to established acute and chronic criteria for the water column. This is also its drawback, because it can only relate to chemicals with established water quality criteria. SEP can only be used for nonpolar organic chemicals. Ionic components are excluded because of the organic carbon factor. In the absence of partitioning data for a specific pollutant, octanol/water partition coefficients are used as estimates. SEP does not account for the interactive effects of chemical mixtures or the effect of a sediment's characteristics (e.g., pH, grain size) on toxicity of a particular chemical.

AET and triad procedures are recommended when chemical mixture criteria are involved.

AET is a field dependent procedure, using concentrations in sediments and one or more indicators of bioavailability/bioeffects, to estimate where significant effects will always be obtained by exceeding a particular level of a contaminant (E.V.S. Consultants, 1990). Thus, the method associates levels of contaminants with effects, but does not establish a causal relationship. Its site-specific capability is one additional advantage. Criteria have already been established for marine waters, and sediment bioassays have been performed with Rhepoxynies abronius (amphipod); Crassostrea gigas (oyster), and Microtox. Depressions of benthic polychaete, mollusc, and amphipod populations were also used to derive AET values for sediments.

Three measures are used in the triad procedure:

- Chemistry to determine sediment contamination;

- Bioassays to determine sediment toxicity; and

- in situ biological changes, including changes in infaunal communities and bottomfish histopathology.

The Triad procedure is useful for broader areas than the site specific application of AET (E.V.S. Consultants, 1990). It's major drawbacks are: further development of criteria are needed; large data bases are required; and methods for bioassays of sediments in the field are not yet standardized. Currently, criteria are only available for $\mathrm{Pb}, \mathrm{PAHs}$, and PCBs. Unmeasured covarying contaminants may influence toxicity of the measured components.

Effects of platforms on benthic communities can vary from reductions in diversity and populations of particular species to increases in diversity and populations of particular species (see section 11). This variation includes increases in diversity at the expense of preexisting species, or increases in numbers of particular 
species while total diversity declines. Some of these results are attributable to the introduction of a new structure (i.e., the platform), as well as the accumulation of contaminants in sediments. In the latter case relatively low levels of contaminants may increase populations (hormesis) of opportunistic species that can either metabolically adapt to the contaminants, or compensate for toxic effects on particular life-stages by increases of more resistant stages in the populations.

E.V.S. Consultants (1990) did a sediment quality triad study on a platform in the Gulf of Mexico, in the vicinity of Matagorda Island, Texas. Chemical enrichment of the sediment was highest at five stations close to the platform (within $25 \mathrm{~m}$ ), as was potential toxicity. Bioassays of chemical extracts showed that hydrocarbon contamination, not metal contamination, was associated with this toxicity. Analyses of benthic infauna found subtle differences that were not easy to distinguish between these five stations and stations further away. In contrast to the evidence of potential toxicity, field-collected data provided evidence of faunal enrichment within a $25 \mathrm{~m}$ radius of the platform, attributable to either the introduction of the platform structure or a hormetic effect of the contaminant mixture in the sediment.

\subsubsection{Suggested Sediment Quality Criteria}

Toxicity determination of sediment contamination has the same problems as assessment of any complex mixture. Currently the SEP approach for individual contaminants is the most widely available procedure for evaluating toxicity of sediments. Adequately-developed AET and triad approaches, will be useful for confirming the validity of an additive SEP approach to toxicity of multiple contaminants. A major stumbling block to application of the AET/triad approaches is the validation and standardization of endpoints for toxicity evaluation.

Sediment criteria (Table 9-3), based on specific levels of probability of toxicological effects that could be related to compilations of a biological effects database (BEDS) for contaminant concentrations in marine and estuarine sediments, were recently updated, but remain generally consistent with those previously reported (Long et al., 1995). 
Table 9-3. Proposed sediment quality criteria (from Long et al., 1995).

\begin{tabular}{|l|c|c|}
\hline & \multicolumn{2}{|c|}{ Sediment Quality Criteria } \\
\hline Contaminant & ERL $^{\mathbf{1}}$ & ERM $^{2}$ \\
\hline Metals & $(\mathrm{ppm})^{3}$ & $(\mathrm{ppm})^{3}$ \\
\hline Arsenic & 8.2 & 70 \\
\hline Cadmium & 1.2 & 9.6 \\
\hline Chromium & 81 & 370 \\
\hline Copper & 34 & 270 \\
\hline Lead & 46.7 & 218 \\
\hline Mercury & 0.15 & 0.71 \\
\hline Nickel & 20.9 & 51.6 \\
\hline Silver & 1.0 & 3.7 \\
\hline Zinc & 150 & 410 \\
\hline Organics & $(\mathrm{ppb})^{3}$ & $(\mathrm{ppb})^{3}$ \\
\hline Total PCBs & 22.7 & 180 \\
\hline Total PAH & 4022 & 44792 \\
\hline Acenaphthene & 16 & 500 \\
\hline Acenaphthylene & 44 & 640 \\
\hline Anthracene & 85.3 & 1100 \\
\hline Fluorene & 19 & 540 \\
\hline 2-Methylnaphthalene & 70 & 670 \\
\hline Naphthalene & 160 & 2100 \\
\hline Phenanthrene & 240 & 1500 \\
\hline Low Molec. Weight-PAH & 552 & 3160 \\
\hline Benzo(a)anthracene & 261 & 1600 \\
\hline Benzo(a)pyrene & 430 & 1600 \\
\hline Chrysene & 384 & 2800 \\
\hline Dibenzo(a,h)anthracene & 63.4 & 260 \\
\hline Fluoranthene & 600 & 5100 \\
\hline Pyrene & 665 & 2600 \\
\hline High Molec. Weight-PAH & 1700 & 9600 \\
\hline ERL: effects range low & & \\
\hline ERM: effects range median & \\
\hline dry weight & & \\
\hline & & \\
\hline & & \\
\hline & & \\
\hline & & \\
\hline
\end{tabular}

BEDS includes a wide variety of adverse biological effects and information derived from all the types of measurements described above.

Concentrations in each study included in BEDS were assigned an effects/no effects descriptor, and ascending orders of concentration were assigned percentile values to describe the distributions. The lower tenth percentile level was identified as the Effects Range Low (ERL) value, the fiftieth percentile was identified the Effects Range Median (ERM) value. Measured sediment values below the ERL value of a contaminant represent a minimal effects range, where effects "would rarely be observed". Concentrations at and above the ERL value, but less than the ERM value, "represent a possible-effects range within which effects would occasionally occur" (Long et al., 1995). Concentrations at or above the ERM value "represent a probable effects range within which effects would frequently occur" (Long et 
al., 1995). In addition to the guideline values, the paper (Long et al., 1995) describes the percent incidence (ratios of data entries) for <ERL, ERL-ERM interval, and >ERM, for 28 chemicals and chemical groups.

\subsection{Histopathological and Genotoxic Effects in Fish}

Several studies have related particular groups of chemicals to increased incidence of histopathological lesions in fish from saline environments. High $\mathrm{PAH}$ concentrations in sediments were associated with hepatic lesions (Johnson et al., 1993; Myers et al., 1991), and biomarkers (Goksøyr et al., 1994) in marine fishes.

Liver neoplasms have only been found in adult fish in field studies (Moore and Stegeman, 1994). Laboratory studies with PAHs have only been able to induce liver tumors by prolonged exposures of fish embryos, larvae and juveniles less than one year of age, while exposures of adults have not been successful. Moore and Stegeman (1994) suggested that preadult stages are more sensitive to tumor induction because of relatively rapid rates of cell replication, and that the field observations are the result of repeated exposures to genotoxic compounds of preadult and adult stages, possibly followed by exposures to epigenetic agents.

Halogenated hydrocarbons and PAHs are found in high levels in harbors on all coasts. Areas such as Boston Harbor and Puget Sound are associated with high levels of neoplasms, especially in the livers, of bottom feeding fish such as the winter flounder, Pleuronectes americanus (Johnson et al., 1993, 1994; Moore and Stegeman, 1994; Myers et al., 1991). Associations were made for PAH and chlordane concentrations in sediments with concentrations in stomach contents of several fish species.

Mixed function oxidase systems in fishes are more developed than the enzyme systems in mollusks, and greater transformation of PAHs are to be expected in fishes than in mollusks. PAHs were studied in feral eels and sediment samples, taken from six sites with different levels of water pollution (van der Oost et al., 1994). There were marked differences between parent PAH profiles in the sediments (mostly four-ring compounds) and the profiles in muscle tissue from the eels (mostly two- and three-ring compounds). Further investigations indicated that PAH-DNA adduct levels in liver cells (32P postlabelling technique) were the best markers for elevated exposures to PAH contamination. These observations on PAH-DNA adduct levels are supported by similar observations from mesocosms studies on flounder, Platichthys flesus (Baan et al., 1994) and laboratory studies by Hellou and coworkers on winter flounder (Pleuronectes americanus). 
Baumann and Harshbarger (1995) attributed a significant decline in neoplasms in catfish to a decrease in measured PAH concentrations in sediments in the Black River, Ohio (1982-1987). These declines were associated with the closing of a coking plant in 1983.

E.V.S. Consultants (1990) recommended that histopathology in bottom fish should be dropped from the AET/triad approaches for several reasons: 1) fish are too mobile to be appropriate for evaluating site-specific effects; 2 ) it will be difficult to establish toxicity indices among geographic areas because of differences in fish assemblages, coupled with interspecific variability in sensitivity to toxic agents; 3 ) intraspecific differences in life-stage sensitivity to toxic materials; and 4) uncertainty of cause-effect relationships between chemical exposures and histopathological lesions.

\subsection{Application to Ecological Risk Assessment for Produced Water Discharges}

Data on the toxicity of produced water chemical components are needed to support an effects assessment. USEPA Water Quality Criteria and suggested sediment criteria can be used in a screening assessment to identify potentially important contaminants and exposure pathways. Limited data are available to describe toxicity to marine organisms native to the Gulf of Mexico, and extrapolating from laboratory studies performed on a standard test organisms adds uncertainty to an assessment. 


\section{RADIONUCLIDE EFFECTS}

\subsection{Quantities and Units}

Traditional units in radiation dose measurements (i.e. $\mathrm{Ci}$, rad, rem) are being replaced by the International System (SI) of units (Bq, Gy, Sv). The names and units (traditional and SI) for activity, absorbed dose and dose equivalent are given in Table 10-1. Prefixes commonly applied to these units are given in Table 10-2.

Table 10-1. Radiological names and units.

\begin{tabular}{|l|l|l|l|l|l|}
\hline Quantity & \multicolumn{2}{|c|}{ Traditional } & \multicolumn{2}{c|}{ SI } & Conversion \\
\hline & Name & Unit & Name & Unit & \\
\hline activity & curie (Ci) & $\begin{array}{l}3.7 \times 10^{10} \\
\text { dis/sec }\end{array}$ & becquerel (Bq) & $1 \mathrm{dis} / \mathrm{sec}$ & $1 \mathrm{~Bq}=2.7 \times 10^{-11} \mathrm{Ci}$ \\
\hline $\begin{array}{l}\text { absorbed } \\
\text { dose }\end{array}$ & rad (rad) & $100 \mathrm{erg} / \mathrm{gm}$ & gray (Gy) & $1 \mathrm{~J} / \mathrm{kg}$ & $1 \mathrm{~Gy}=100 \mathrm{rad} \cdot$ \\
$\begin{array}{l}\text { equivalent } \\
\text { dose }\end{array}$ & rem (rem) & $100 \mathrm{erg} / \mathrm{gm}$ & sievert (Sv) & $1 \mathrm{~J} / \mathrm{kg}$ & $1 \mathrm{~Sv}=100 \mathrm{rem}$ \\
\hline
\end{tabular}

Table 10-2. Prefixes used in radiation protection.

\begin{tabular}{|l|l|}
\hline pico. $(\mathrm{p})$ & $10^{-12}$ \\
\hline nano $(\mathrm{n})$ & $10^{-9}$ \\
\hline micro $(\mu)$ & $10^{-5}$ \\
\hline milli $(\mathrm{m})$ & $10^{-3}$ \\
\hline kilo $(\mathrm{k})$ & $10^{3}$ \\
\hline mega $(\mathrm{M})$ & $10^{6}$ \\
\hline giga $(\mathrm{G})$ & $10^{9}$ \\
\hline tera $(\mathrm{T})$ & $10^{12}$ \\
\hline
\end{tabular}

Radioactivity is quantified in terms of the number of spontaneous energy emitting transformations per unit time -- a quantity known as activity. An example of a transformation is the decay of a radium 226 nucleus into a radon 222 nucleus, an alpha particle and gamma rays. The unit of activity has historically been the curie (Ci). One curie is equal to $3.7 \times 10^{10}$ disintegrations per second. In the SI system, the basic unit of activity has been redefined as one disintegration per second, known as the becquerel $(\mathrm{Bq})$. One curie is equal to $3.7 \times 10^{10} \mathrm{~Bq}$.

The biological effects of exposure to a radionuclide are related to the absorbed dose and dose rate. The absorbed dose is a measure of the energy imparted to matter. An absorbed dose of $100 \mathrm{erg} / \mathrm{gram}$ is called $1 \mathrm{rad}$. In the SI system of 
units, the unit of absorbed dose is the Gray (Gy, 1 Joule/kilogram). An absorbed dose of $1 \mathrm{rad}$ is equal to $0.01 \mathrm{~Gy}$ ( $1 \mathrm{~Gy}=100 \mathrm{rads}$ ).

The probability of stochastic effects (i.e. cancer and genetic effects) depends not only on the absorbed dose, but also on the type and energy of the radiation causing the dose and on the organs or tissues irradiated. Factors have been developed by the International Commission on Radiological Protection (ICRP, 1991) to account for these relationships in humans.

Radiation weighting factors are used to account for the differences in relative biological effectiveness (RBE) of different radiations. In the past these differences were accounted for by use of quality factors. The radiation weighting factor for gamma radiation $(\gamma)$ and beta $(\beta)$ particles has been assigned a value of 1 . The weighting factor for alpha $(\alpha)$ particles is set to 20 . The absorbed dose modified by the weighting factor is called the equivalent dose and is expressed in units of Joules per kilogram with the name Sievert (Sv) given to 1 Joule/kg. The traditional unit is the rem (see Table 10-1). One Sievert is equal to $100 \mathrm{rem}$.

Tissue weighting factors are used to account for differences in the sensitivity to cancer induction of different human tissues and organs. A tissue weighting factor represents the relative contribution of that organ or tissue to the total effects resulting from uniform irradiation of the whole body. These factors are given in ICRP (1991). The equivalent dose weighted by these tissue weighting factors is referred to as the effective dose. For a uniform, whole body exposure, the equivalent and effective doses have the same value, and are both expressed in units of Sieverts (Sv).

The limited data for the relative biological effectiveness of various radiation types in man indicate that the RBE can be expected to be similar for aquatic organisms, (Woodhead, 1984), because the soft tissues of man and other organisms are generally similar in terms of water content and basic cell structure (IAEA, 1988). IAEA (1988) suggested that it is reasonable to apply the same quality factors (now radiation weighting factors) derived for humans to doses received by aquatic organisms. There are no parallel tissue weighting factors for aquatic organisms, and the usual approach to estimating doses to aquatic animals to assume that the dose is averaged over the whole body of the organism. NCRP (1991) suggests this approach is reasonable, as long as the average whole body exposure is representative of the dose to the gonads. NCRP also suggests that it may be useful to estimate the dose to the most highly exposed tissue (NCRP, 1991). 


\subsection{Dosimetry}

An aquatic organism may be irradiated externally by radionuclides in water and sediment, and internally by radionuclides taken into the body by ingestion or direct absorption. Most incorporated radionuclides are differentially distributed among the organs and tissues of the organism. Radium, for example, tends to accumulate in bone, skin and exoskeleton.

\subsubsection{Model Codes and Dose Conversion Factors}

NCRP (1991) reviewed several models useful for estimating dose to aquatic animals. Models described include CRITR (Soldat et al., 1974), EXREM III, and BIORAD (Trubey and Kaye, 1973).

CRITR (Soldat et al., 1974) allows calculation of radionuclide concentrations in water, sediment and two groups of organisms from an effluent discharged to surface waters. Concentration factors are used to estimate the equilibrium body burden of a radionuclide. Radionuclides are assumed to be uniformly distributed throughout the body. It is assumed that all of the energy emitted from $\alpha$ and $\beta$ particles inside the body is absorbed within the body. The model uses a set of values derived for muscle-tissue spheres of different radii to account for the effective absorbed energy per dose from $\gamma$ rays. Dose rates are calculated based on assumed occupancy factors, and dose rates from water are tabulated for the geometry of the human body and assumed to apply to the organisms studied. Dose from radionuclides in the sediment is also considered.

EXREM III and BIORAD (Trubey and Kaye, 1973) use a concentration factor approach to estimate the concentration of a radionuclide in organisms from the concentration in water. Dose rates from radionuclides in water are derived from the mean dose rate in an effectively infinite uniformly contaminated source. The dose rate from radionuclides accumulated by the organism are based on the effective absorbed energy per disintegration for radionuclides in a sphere of 30 $\mathrm{cm}$ (except for muskrat: $10 \mathrm{~cm}$ ). No exposure from the sediment is considered.

IAEA (1988) developed dose conversion factors that relate the radiation exposure to an organism to a unit concentration of the radionuclide in the water in which the organism lives (Table 10-3). These dose conversion factors are based on models using assumptions concerning the bioaccumulation factor, $\mathrm{K}_{\mathrm{d}}$, and the sizes and shapes of the animals (see IAEA, 1988). These factors may be useful for screening purposes. 
Table 10-3. IAEA dose conversion factors ( $\mathrm{mSv} / \mathrm{hr}$ per $\mathrm{Bq} / \mathrm{m}^{3}$ ).

\begin{tabular}{|l|l|l|l|l|}
\hline ORGANISM & ${ }^{226} \mathrm{Ra}$ & ${ }^{228} \mathrm{Ra}$ & ${ }^{210} \mathrm{~Pb}$ & ${ }^{210} \mathrm{Po}$ \\
\hline & & & & \\
\hline FISH & & & & \\
\hline bathypelagic & $1.38 \times 10^{-4}$ & $1.62 \times 10^{-7}$ & $4.96 \times 10^{-8}$ & $1.22 \times 10^{-4}$ \\
\hline benthic & $1.45 \times 10^{-4}$ & $3.83 \times 10^{-6}$ & $8.00 \times 10^{-6}$ & $1.22 \times 10^{-4}$ \\
\hline & & & & \\
\hline MOLLUSKS & $2.85 \times 10^{-4}$ & $4.41 \times 10^{-6}$ & $8.51 \times 10^{-5}$ & $6.10 \times 10^{-4}$ \\
\hline & & & & \\
\hline CRUSTACEANS & & & & \\
\hline large, bathypelagic & $2.77 \times 10^{-5}$ & $2.82 \times 10^{-8}$ & $2.46 \times 10^{-7}$ & $3.05 \times 10^{-3}$ \\
\hline large, benthic & $3.54 \times 10^{-5}$ & $4.03 \times 10^{-6}$ & $1.82 \times 10^{-5}$ & $3.05 \times 10^{-3}$ \\
\hline small, bathypelagic & $2.76 \times 10^{-5}$ & $1.86 \times 10^{-8}$ & $1.67 \times 10^{-7}$ & $1.83 \times 10^{-3}$ \\
\hline small, benthic & $3.70 \times 10^{-5}$ & $4.76 \times 10^{-6}$ & $6.14 \times 10^{-4}$ & $1.83 \times 10^{-3}$ \\
\hline & & & & \\
\hline
\end{tabular}

\subsubsection{IAEA (1976) Method}

IAEA (1976) presents a method for estimating the dose to aquatic organisms for radionuclides in water, sediment and accumulated in tissue. The method outlined here is similar to many of the assumptions and models used in the previously discussed codes, but affords greater flexibility in using site specific data and assumptions.

\section{Dose Rates From Incorporated Radionuclides}

Mollusks, crustaceans and fish are large in relation to the range of $\alpha$ and $\beta$ particles. It is assumed that no significant portion of the total energy emitted by incorporated radionuclides in the form of $\alpha$ and $\beta$ particles is dissipated in the surrounding water. The dose rate from $\alpha$ and $\beta$ particles closely approach the dose rate in an infinite volume, uniformly contaminated with the radionuclide.

$$
D_{(\infty)}=2.13 \text { E C } \mu \mathrm{rad} / \mathrm{hour}
$$

where:

$D_{(\infty)}$ is the dose rate $(\alpha$ or $\beta$ ) in an infinite volume,

$E$ is the average energy ( $\alpha$ or $\beta$ ) MeV per disintegration, and

$C$ is the activity of the radionuclide in the organism (pCi/gram). 
To estimate the dose from $\gamma$ rays the dimensions and geometry of the organism are needed. The average dose rate from internal gamma radiation is given by:

$D_{\gamma}=\Gamma C \rho g \times 10^{-3} \mu \mathrm{rad} /$ hour

where:

$\Gamma$ is the specific $\gamma$ ray constant in $\mathrm{cm}^{2}$. rad $/ \mathrm{hr}^{-\mathrm{mCi}^{-1}}$

$C$ is the specific activity in the organism (pCi/gram)

$\rho$ is the density of the organism

$\mathrm{g}$ is the mean geometrical factor in $\mathrm{cm}$ (Loevinger et al., 1956)

IAEA (1976) uses specific dimensions and geometrical factors, but other values can also be used in estimating dose. The idealized dimensions and geometrical factors used in IAEA (1976) are as follows:

Mollusks: flat cylinder, $1 \mathrm{~cm}$ high, $4 \mathrm{~cm}$ in diameter. $\mathrm{g}=10 \mathrm{~cm}$ Crustaceans: cylinder, $15 \mathrm{~cm}$ long, $6 \mathrm{~cm}$ in diameter. $\mathrm{g}=25 \mathrm{~cm}$ Fish: cylinder, $50 \mathrm{~cm}$ long and $10 \mathrm{~cm}$ diameter. $\mathrm{g}=41 \mathrm{~cm}$

The tissue density is assumed to be 1 and the activity is assumed to be uniformly distributed throughout the volume. This assumption may result in an underestimate of the dose to some tissue, since radium tends to accumulate in bone and shell.

\section{Dose Rates From Radionuclides in Water}

For mollusks, crustaceans and fish IAEA (1976) assumes that external $\alpha$ and radiation from the sea water $\gamma$ ray-dose is taken to be $D(\infty)$.

$$
D_{(\infty)}=2.13 E C \mu \mathrm{rad} / \text { hour }
$$

\section{Dose Rates From Radionuclides in Sediment}

The $\gamma$ and $\beta$ radiation dose rate above sediments has been taken to be approximately equal to $0.5 D_{(\infty)}$. The dose from $\alpha$ radiation is assumed to be negligible.

\subsection{Effects on Individuals and Populations}

Exposure to ionizing radiation can result in injury at the molecular, cellular and whole body levels. Most of the available studies of the effects of radiation on aquatic organisms are concerned with the induction of deterministic, somatic effects. These effects include increases in mortality and pathophysiological, developmental and reproductive effects. There is little information available 
concerning induction of cancer and genetic effects, although a few studies of stochastic genetic effects in organisms are available (Anderson and Harrison, 1986).

Reproductive and early developmental systems of vertebrates are the most sensitive to radiation, and invertebrates appear to be relatively resistant (NCRP, 1991).

Most studies of the effects of radiation on aquatic organisms were performed in the laboratory, with effects determined on individual animals. A few studies of the effects of radiation on natural populations have been performed. The most important consideration in assessing the effects of radionuclides discharged in produced water is the effect radiation exposure has on reproductive success in populations, and consequences in populations and ecosystems. If exposures are limited to protect fertility and fecundity of the population as a whole, it is unlikely that other effects in individuals will be important to the population (NCRP, 1991).

IAEA (1976) and Templeton (1980) examined the possible effects of chronic, low level radiation on recruitment, fecundity and mortality by considering the known regulatory mechanisms of natural populations. Recruitment for highly fecund species is not directly related to standing stock size and the mortality rate operating on eggs and larvae varies from year to year. Survival of eggs and larvae depend to a large degree on the availability of food, and a large number of eggs are produced at each spawning (Templeton, 1980). Density dependent mortality reduces fish larvae populations to the level that can be supported by the available food. If mortality is enhanced by low levels of radiation, recruitment to the stocks of highly fecund fish is not likely to be affected, unless the stocks are already at risk due to over-exploitation or other environmental stresses (IAEA, 1976; IAEA, 1988; NCRP, 1991).

For species with low fecundity (e.g., sharks and marine mammals), recruitment is closely related to parent stock size. It is not possible to predict the effects on recruitment for these species, although effects could be more significant than for highly fecund species. However, at low dose rates, it is reasonable to assume that effects will be small compared to fishing and other pressures (IAEA, 1976). For species with special social value (endangered and threatened species, marine mammals) effects on individuals may be of importance.

Effects at the ecosystem level have been demonstrated only for the large doses received at Eniwetok and Bikini atolls in the Pacific Proving Grounds (Templeton, et al., 1971).

The National Council on Radiation Protection and Measurements recently reviewed the literature on the effects of ionizing radiation on aquatic organisms, 
and suggested reference levels that would protect aquatic populations (NCRP, 1991). Major conclusions of this review included:

- Experimental studies in the laboratory have shown detectable effects on fecundity down to $10 \mathrm{mGy} / \mathrm{d}$.

- Effects not necessarily deleterious at the population level have been detected at dose rates between 1 and $10 \mathrm{mGy} / \mathrm{d}$. Deleterious effects on natural populations were observed at dose rates $\geq 10 \mathrm{mGy} / \mathrm{d}$. Clearly deleterious effects which would be detected at the population level appear in the range of $10-100 \mathrm{mG} / \mathrm{d}$.

- Lowest dose rate causing no effect in natural populations: $0.5 \mathrm{mGy} / \mathrm{d}$; lowest dose rate causing no effect in laboratory: $10 \mathrm{mGy} / \mathrm{d}$.

NCRP (1991) suggests a reference dose rate to protect aquatic populations of $10 \mathrm{mGy} / \mathrm{d}$. NCRP also suggests a detailed assessment if an initial analysis results in estimated dose rate above $2.4 \mathrm{mGy} / \mathrm{d}$.

IAEA (1988) came to similar conclusions, but expressed their reference levels in terms of dose equivalent rather than absorbed dose. IAEA (1988) concluded that:

- increased mortality is expected above $10 \mathrm{mSv} / \mathrm{hr}(240 \mathrm{mSv} / \mathrm{d})$;

- reduced reproductive success may occur between 1 and $10 \mathrm{mSv} / \mathrm{hr}(24-$ $240 \mathrm{mSv} / \mathrm{d}$ );

- some somatic effects which would be eliminated by natural selection could occur between 0.004 and $1 \mathrm{mSv} / \mathrm{hr}(0.1-24 \mathrm{mSv} / \mathrm{d})$; and

- no adverse effects are expected below background levels of $0.004 \mathrm{mSv} / \mathrm{hr}$ $(0.1 \mathrm{mSv} / \mathrm{d})$.

\subsection{Application to Ecological Risk Assessment for Produced Water Discharges}

Estimates of external and external dose and doses associated with individual and population effects are needed in an effects assessment for radionuclides discharged in produced water. Generic dose-factors can be used in a screening assessment to identify potential important contaminants and exposure pathways. There is uncertainty in the doses to marine organisms that may be expect to result in effects on individuals or populations, but estimates are available. 


\section{EFFECTS ON BENTHIC COMMUNITIES}

\subsection{Introduction}

Effects of platforms and platform discharges on benthic communities can vary from reductions in diversity and populations of particular species to increases in diversity and populations. This variation includes an increase in diversity at the expense of preexisting species, or an increase in numbers of particular species while total diversity declines. Some of these results are attributable to the introduction of a new structure (i.e., the platform), as well as the accumulation of contaminants in sediments. In the latter case relatively low levels of contaminants may increase populations (hormesis) of opportunistic species that can either metabolically adapt to the contaminants, or compensate for toxic effects on particular life-stages by increases of more resistant stages in the populations. Sparse densities around the platforms can be caused by any combination of the following three scenarios (Harper et. al., 1981):

1. a toxic substance from the platforms is periodically killing organisms relatively quickly after settling, causing a low abundance and a high turnover rate;

2. the harder substrate in the vicinity of the platforms is unsuitable for habitation for many of the benthos; and

3. the fish and larger invertebrates that congregate around the platform prey heavily on the benthic fauna.

Benthic community impacts were associated with levels of produced water chemical constituents in the sediments which generally decreased with distance from the discharge point. The threshold concentration of contaminants at or above which the benthic community was affected varied among study areas. These differences are a function of the loading to the environment, the sedimentary characteristics of the environment and the type of benthic community (Rabalais et al., 1991). This section summarizes studies of the effects of produced water on benthic communities. Conclusions and findings for each study are described, and where available, threshold levels are presented. In most cases it is not clear if the effect identified was due to toxic exposure or from confounding factors (e.g., substrate removed from the platform, background levels, etc.). Other controlling factors specific to the site must also be considered. For example, sediment grain size is an important parameter because fine-grained sediments have a greater capacity for binding organic and metal pollutants than do coarse sediments, and is an important factor in the structure of benthic communities. These site specific assessments may be of limited use for predictive analysis. 


\subsection{Coastal Studies}

\section{Boesch and Rabalais (1989a)}

Boesch and Rabalais (1989a) studied coastal canal environments that received produced water discharges and found that the benthic habitats were disturbed even without the effects of produced water contaminants. The studied environments are channels; in which fine sediments accumulate; which are periodically dredged; and in which vessel traffic disturbs the bottom. Consequently, the benthic fauna is of low diversity and is composed of opportunistic species, including the polychaetes, Stresblospoi benedicti, Mediomastus ambiseta and Capitella capitata and the bivalve, Mulinia lateralis. At locations closest to the discharge, where bottom sediments were heavily contaminated, the macrobenthic fauna was essentially eliminated. Low densities of organisms and few species were found under conditions of moderate hydrocarbon contamination of sediments. Although some relatively uncontaminated sediments had a sparse benthic fauna, high PAH levels in sediments were always associated with a depauperate benthos.

The authors selected three coastal study sites for a general chemical and biological assessment: Bayou Riguad, behind Grand Isle; Pass Fourchon; and the bay side of East Timbalier Island. These sites were chosen because of large produced water discharges and because they represented different hydrological conditions (Table 11-1). These general surveys showed evidence of biological effects in terms of: reduced density and diversity of macrobenthic organisms in contaminated sediments; and the accumulation of petroleum hydrocarbon in the tissues of filter feeding mollusks proximate to the discharge sites.

Table 11-1. General characteristics of study areas (adapted from Boesch and Rabalais, 1989a).

\begin{tabular}{|l|l|l|l|}
\hline Site & $\begin{array}{l}\text { Volume } \\
\text { (bbl/day) }\end{array}$ & Receiving Environment & Flow Regime \\
\hline \hline Bayou Rigaud & 150,000 & $\begin{array}{l}\text { Into terminus of deep slip (7 } \\
\text { m) off Bayou Rigaud }(4.5 \mathrm{~m}) \\
\text { and via holding tank and } \\
\text { aeration system to drainage } \\
\text { ditch }(4 \mathrm{~m}) \text { leading to Bayou } \\
\text { Rigaud }(5.5 \mathrm{~m})\end{array}$ & $\begin{array}{l}\text { Tidally energetic, swift } \\
\text { bottom currents }\end{array}$ \\
\hline Pass Fourchon & 45,000 & $\begin{array}{l}\text { Into dead-end dredged } \\
\text { channel }(2.5 \mathrm{~m}) \text { near occluded } \\
\text { end of Pass Fourchon }(3 \mathrm{~m})\end{array}$ & $\begin{array}{l}\text { Less energetic tidal flow, } \\
\text { dead-end closed }\end{array}$ \\
\hline $\begin{array}{l}\text { East Timbalier } \\
\text { Island }\end{array}$ & 112,930 & $\begin{array}{l}\text { Into dredged canals }(1.5-2 \mathrm{~m}) \\
\text { near open bay }\end{array}$ & $\begin{array}{l}\text { Dredged canals with } \\
\text { reduced flow; open bay, } \\
\text { shallow, well-mixed from } \\
\text { waves and tidal currents }\end{array}$ \\
\hline
\end{tabular}




\section{Rabalais et al., (1991)}

In an expansion of the previous study (Boesch and Rabalais, 1989a) Rabalais et al., (1991) sampled Pass Fourchon, Bayou Rigaud, and East Timbalier Island in more detail and four additional sites (Emeline Pass, Eugene Island, Romere Pass and Empire Waterway). Within each of the study areas, a series of stations was designed for a general assessment of the fate and effects of produced water discharges in the receiving environment.

\section{Pass Fourchon}

The benthic infauna of the Pass Fourchon study area was composed primarily of polychaetes, with Streblospio benedicti being dominant. Another polychaete opportunist, Mediomastus ambiseta, was common in the May 1989 collections. The bivalve, Mulinia lateralis, was numerous during February 1990 and was common during the other sample dates. The benthic fauna included additional polychaete species, a few bivalves and gastropods, nemertean worms, oligochaetes and pericaridean crustaceans.

In most cases, benthic infauna was absent or substantially reduced at 400,500 , 600 , and $800 \mathrm{~m}$ from the discharge point. Infauna was reduced in the deeper parts of the channel where the effluent density plume followed the bottom contours, but was present at higher topographic locations not impacted by the effluent. The benthic fauna at distances greater than $800 \mathrm{~m}$ was not impacted by the discharge.

Rabalais et al., (1991) concluded that there were obvious relationships between the number of species and individuals collected at a station to the amount of chemical constituents in near bottom waters or surficial sediments. Where the chemical contaminants exceeded a threshold level, the numbers of benthic fauna were either severely depressed or absent. Table 11-2 summarizes threshold concentrations of contaminants in the sediments and bottom waters above which benthic fauna was depressed. 
Table 11-2. Threshold concentrations of chemical constituents in near-bottom waters and surficial sediments at or above which benthic fauna was depressed at Pass Fourchon (adapted from Rabalais et al., 1991)

\begin{tabular}{|l|c|c|}
\hline \multicolumn{1}{|c|}{ Chemical Constituent } & $\begin{array}{c}\text { Threshold } \\
\text { (for species) }\end{array}$ & $\begin{array}{c}\text { Threshold } \\
\text { (for Individuals) }\end{array}$ \\
\hline \hline \multicolumn{1}{|c|}{ Near-Bottom Water } & $(\mu \mathrm{g} / \mathrm{l})$ & $(\mu \mathrm{g} / \mathrm{l})$ \\
\hline Volatiles & 25 & 5.8 \\
\hline Alkylated PAH & 0.9 & 0.9 \\
\hline Total PAH & 1.6 & 1.6 \\
\hline Total Saturated HC & 38 & 38 \\
\hline \hline Surficial Sediments & $(\mu \mathrm{g} / \mathrm{g})$ & $(\mu \mathrm{g} / \mathrm{g})$ \\
\hline Alkylated PAH. & 5,900 & 5,900 \\
\hline Total PAH & 6,200 & 6,200 \\
\hline Total Saturated HC & 250,000 & 50,000 \\
\hline
\end{tabular}

\section{Bayou Rigaud}

The benthic infauna of the Bayou Rigaud study area was a combination of marine and intermediate salinity organisms. The dominants of the benthic community were the polychaete, Stroblospio benedicti, and the bivalve, Mulinia lateralis. Numerous other polychaetes, bivalves, gastropods, nemertean worms, oligochaetes and pericaridean crustaceans were also collected.

While there were no severely depressed fauna, there were indications that some of the stations had fewer species and individuals than other stations. The benthic community parameters of number of species and individuals were not related to the grain size distribution. There was a relationship with the total organic carbon of the sediments; with the number of individuals being greater in sediments with higher organic content. The sample data was an influential factor on both the number of species and individuals, as shown in the coanalysis of variance. Numbers were higher in both of the February samples, reduced in May and lowest in October. In stepwise multiple regressions of environmental parameters important in determining the variation in number of species and individuals, the sample data was the first factor identified. With regards to number of species, there was only one more factor identified in the stepwise multiple regression as being important in explaining the variation among the means; this was sediment barium concentration. Sediment $\mathrm{Ba}$ concentration and total organic content were identified in the stepwise multiple regression for number of individuals as significant factors explaining the variation. 
Non-linear relationships with several sediment chemical constituents identified threshold values above which number of species or number of individuals were usually depressed below background levels (Table 11-3). There were no observed threshold levels of chemical constituents in near-bottom waters above which the benthic fauna was depressed.

Table 11-3. Threshold concentrations of chemical constituents in surficial sediments at or above which benthic fauna was depressed at Bayou Rigaud (adapted from Rabalais et al., 1991).

\begin{tabular}{|l|l|l|}
\hline \multicolumn{1}{|c|}{ Chemical Constituent } & \multicolumn{1}{|c|}{$\begin{array}{c}\text { Threshold (for } \\
\text { species) }\end{array}$} & \multicolumn{1}{|c|}{$\begin{array}{c}\text { Threshold } \\
\text { (for } \\
\text { Individuals) }\end{array}$} \\
\hline \hline \multicolumn{1}{|c|}{ Surficial Sediments $(\mu \mathrm{g} / \mathrm{g})$} & & \\
\hline Parent PAH & N/A & 740 \\
\hline Alkylated PAH & N/A & 7,700 \\
\hline Total PAH & N/A & 9,700 \\
\hline Total Saturated HC & 300,000 & 240,000 \\
\hline Barium & N/A & 440 \\
\hline
\end{tabular}

\section{East Timbalier Island}

The benthic infauna community for the East Timbalier Island study area was characterized by marine fauna of mostly polychaetes and a few bivalves, gastropods, amphipods, isopods, cumaceans and nemerteans. There were large numbers of the opportunistic polychaetes Streblospio benedicti, Mediomastus ambiseta and Capitella capitata.

The benthic community parameters of number of species and number of individuals were related to some of the sedimentary characteristics and some sediment chemical constituents (Table 11-4), but the relationships were not consistent between the stations in the north-south transect and those in the east-west transect. In general there were more species and more individuals at stations in the north-south transect, with regard to increased sand content and reduced sediment organic content. For the east-west transect, there were more species and more individuals with reduced sand content and higher total organic carbon in the sediments. Where relationships were apparent with the benthic fauna and sediment hydrocarbon contamination, these relationships were stronger for stations in the north-south transect than the east-west. 
Table 11-4. Threshold concentrations of chemical constituents in surficial sediments at or above which benthic fauna was depressed at East Timbalier Island (adapted from Rabalais et al., 1991).

\begin{tabular}{|l|l|l|}
\hline \multicolumn{1}{|c|}{ Chemical Constituent } & \multicolumn{1}{|c|}{$\begin{array}{c}\text { Threshold (for } \\
\text { species) }\end{array}$} & \multicolumn{1}{|c|}{$\begin{array}{c}\text { Threshold } \\
\text { (for } \\
\text { Individuals) }\end{array}$} \\
\hline \hline \multicolumn{1}{|c|}{ Surficial Sediments $(\mu \mathrm{g} / \mathrm{g})$} & & \\
\hline Alkylated $\mathrm{PAH}$ & 5,000 & 5,000 \\
\hline Total PAH & 5,700 & 4,700 \\
\hline Total Saturated HC & 150,000 & 150,000 \\
\hline $\mathrm{Zn}$ & 58 & 58 \\
\hline
\end{tabular}

\section{Emline Pass}

The benthic macroinfaunal community of Emline Pass was characterized by the following groups: haustoriid amphipods, nemertean worms, and a few species of bivalves, gastropods and polychaetes. Haustoriid amphipods are typical infauna of high energy, sandy marine intertidal beach zones. The high energy, sandy environment at Emline Pass is the result of fast river currents. There were few or no individuals of benthic organisms at most Emline Pass stations (Rabalais et al., 1991)

There were no relationships between the number of species and individuals in the benthic samples to various constituents of the sediments, either grain size distribution, organic content or hydrocarbon contamination. There was also little variability in the benthic community composition with overall low diversity and abundances throughout the transect. There was a slight depression in the number of species and individuals with elevated concentrations of $\mathrm{Al}$ and $\mathrm{Ni}$ in the surface sediments. The distribution of these elevated metals, however, was not related to distance from the discharge facility (Rabalais et al., 1991).

\section{Eugene Island}

The benthic macrofauna was typical of a brackish to intermediate salinity fauna and composed primarily of polychaetes. The dominant polychaete was the opportunist, Kediomastus ambiseta. Other organisms included nemertean worms, oligochaetes, insect larvae, pericaridean crustaceans and a few bivalves and gastropods.

The general trend for Eugene Island was reduced numbers of species and individuals at the discharge point and at some stations near the discharge point. Differences among stations were minimal at distances greater than $300 \mathrm{~m}$. There were reductions in both the number of species and number of individuals 
in relation to certain chemical constituents of the surface sediments. These relationships were stronger for number of individuals than for number of species, but the species richness for the study area was relatively low. The threshold for an effect in the benthic fauna was lower for the number of individuals than for the number of species (Table 11-5).

Table 11-5. Threshold concentrations of chemical constituents in surficial sediments at or above which benthic fauna was depressed at Eugene island (adapted from Rabalais et al., 1991).

\begin{tabular}{|l|c|c|}
\hline \multicolumn{1}{|c|}{ Chemical Constituent } & $\begin{array}{c}\text { Threshold (for } \\
\text { species) }\end{array}$ & $\begin{array}{c}\text { Threshold } \\
\text { (for } \\
\text { Individuals) }\end{array}$ \\
\hline \hline \multicolumn{1}{|c|}{ Surficial Sediments } & $(\mu \mathrm{g} / \mathrm{g})$ & $(\mu \mathrm{g} / \mathrm{g})$ \\
\hline Parent PAH & N/A & 190 \\
\hline Alkylated PAH & 430 & 430 \\
\hline Total PAH & 2,100 & 520 \\
\hline Total Saturated HC & 31,000 & 31,000 \\
\hline Barium & 500 & 370 \\
\hline Aluminum & N/A & 12,000 \\
\hline
\end{tabular}

\section{Romere Pass}

The benthic infauna of the Romere Pass study area was typical of both fresh and brackish environments. Organisms were bivalves, nemertean worms, oligochaetes and a few amphipods, polychaetes and gastropods.

There were statistical differences among stations for three of the benthic community parameters calculated. The differences were not obviously related to proximity to a discharge point, and there was considerable overlap in the station means.

\section{Empire Waterway}

The benthic infauna of the Empire Waterway study area was a combination of marine and intermediate salinity organisms, primarily polychaetes. There were also oligochaetes, nemertean worms, bivalves, gastropods, ophiuroids and decapod crustaceans.

There were no relationships between the number of species and number of individuals and sediment grain size and total organic content. The sediments, however, were uniformly composed of a majority of silts and TOC values were generally $2 \%$ for most samples. Similarly, there were no relationships of the 
benthic fauna with most of the sediment contaminants. Concentrations in the sediments, however, were generally low throughout the study area. There was a pronounced decrease in number of species and number of individuals at a station near an abandoned discharge site. These reductions were related to elevated levels of alkalyted PAH above $60 \mathrm{ppb}$. The vertical core for this station also indicated an accumulation of petrogenic hydrocarbons subsurface and at depth.

\section{Lake Pelto (Neff et al., 1989)}

Neff et al. (1989) studied an estuarine site in Terrebonne Bay, Louisiana at Lake Pelto Tank Battery No. 1.

The benthic fauna at Lake Pelto was dominated by Mediomastus ambiseta. The dominant taxa at all stations were short lived, opportunistic species such as the polychaetes $M$. ambiseta and Streblospio benedicti and the bivalve mollusk Mulinia lateralis. These species are characteristic of communities under natural environmental or pollutant stress. The authors hypothesized that this condition was caused by factors such as high suspended sediment loads attributable to the Mississippi River outflow and periodic bottom water hypoxia, neither of which are related to discharges from coastal exploration/production operations.

Benthic communities at Lake Pelto, Tank Battery No. 1 were more diverse than those at an offshore platform sampled in the same study (see Eugene Island, Block 105). Stations nearest the platform with the coarsest sediment had the highest diversities. Similar analysis revealed that communities at two stations $20 \mathrm{~m}$ from the platform were very similar but unique in comparison from the other stations. The fauna from stations $1000 \mathrm{~m}$ from the platform also were distinct from fauna from other stations.

Neff et al. summarized that grain size was the most important parameter contributing to gradients of benthic community structure around the platform. Benthic communities within about $20 \mathrm{~m}$ of both platforms were influenced by sediment contamination probably derived from produced water discharges. Benthic communities located 100 to $1000 \mathrm{~m}$ from the platform exhibited no evidence of impacts attributable to platform discharges. Neff et al. concluded that relatively minor effects on benthic communities resulting from chronic produced water discharges to shallow estuarine and coastal waters of the northern Gulf of Mexico were restricted to small areas around the platforms.

\section{Trinity Bay, Texas (Armstrong, et al., 1977)}

Armstrong et al., (1977) performed a 21-month study on the effects of produced water effluent from a shallow water (eight ft) oil separator platform on the surrounding benthic fauna of Trinity Bay, a shallow Texas estuary (six to nine ft). 
The effluent was discharged three feet from the bottom. Bottom samples were collected monthly and analyzed for naphthalene concentration, number of species and number of individuals. The concentration of total napthalenes (i.e., napthalenes, methylnapthalenes, dimethylnapthalenes) was used to indicate the presence of petroleum hydrocarbons in the water and sediments.

Fifteen stations were established in Trinity Bay along three transects radiating outward from the C-2 Separator Platform. The station and their distances ranged from $50 \mathrm{ft}$ to $19,00 \mathrm{ft}$ from the platform.

The study found the highest levels of naphthalenes were in sediments within 50 feet of the shallow water $(8 \mathrm{ft})$. The mean concentration at station 1 over the 21 month study was $18-21 \mathrm{ppm}$. Stations located $250 \mathrm{ft}$ from the outfall had mean total naphthalene concentrations $20-50 \%$ of those at station 1 . Stations 1,500 feet from the outfall had total naphthalene concentrations at or near background levels. Benthos was shown to be depressed in the immediate vicinity of the $\mathrm{C} 2$ separator platform. The bottom was found to be almost completely devoid of benthos within 50 feet of the outfall and severely depressed for a radius of 500 feet.

Near the platform there was an inverse correlation between relative concentration of naphthalenes in the sediments and the number of benthic animals. Station 1 was almost completely devoid of benthos, and had an average naphthalene concentration almost twice that of any other station. Outer stations that were unaffected had 0 to $<1 \mathrm{ppm}$ concentrations of naphthalenes.

The authors concluded that other than seasonality, natural environmental factors did not appear to play a part in the distribution and abundance of benthos, since sediment type was the same for all stations, as was salinity, temperature and depth of water.

\subsection{Offshore Benthic Communities}

\section{The Offshore Ecology Investigation (OEI)}

The Offshore Ecology Investigation (OEI) was a field study to assess the cumulative ecological effects of normal oil and gas drilling and production operations on estuarine and near shore ecosystems. It was designed to study the effects of persistent exposure of an estuary and the adjacent offshore area to the low level discharge of contaminants and the physical disturbance associated with prolonged and intensive drilling and production operations (Menzies et al. 1979). The experimental design used to accomplish these objectives included the study of point source discharges based on data sets taken synoptically at active platform experimental sites and at control sites both in Timbalier Bay and offshore Louisiana (Bender et al., 1979). 
All samples contained pelecypods, gastropods, amphipods and cumaceans. On the basis of the offshore benthic biological data the authors found no indication that the benthic macroinvertebrate community has been altered as a result of offshore oil production in Louisiana.

The study concluded that analysis of the benthic biological data in Timbalier Bay and offshore waters does not indicate any environmental stress resulting from oil drilling and production activities. Variation in biota are the result of variability in salinity or turbidity. The study presented the following four major conclusions.

1) Timbalier has not undergone significant ecological change as a result of petroleum drilling production since just prior to 1952 when other more limited baseline data were generated. 2) Every indication of good ecological health is present. The region of the sampling sites is a highly productive one from the biological standpoint, more so than other regions thus far studied in the eastern and open Gulf of Mexico. 3) Concentration of all compounds which are in any way related to drilling or production are sufficiently low to present no known persistent biological hazard. 4) Natural phenomena such as seasonality, floods, upwellings, and turbid layers have much greater impact upon the ecosystem than do petroleum drilling and production activities.

These conclusions were contested by Sanders (1981). With regard to benthic fauna Sanders argued that the studied area was not indicative of a healthy ecosystem. In comparing the densities of organisms in the OEI study with those found in shallow marine habitats elsewhere in the world, the OEl densities were significantly lower. Also, Sanders interpreted the presence of large numbers of two opportunistic species, Mulinia lateralis and Spiochaetopterus oculatus, as indicative of polluted conditions in the study area.

\section{The Central Gulf Platform Study}

Four primary sites and four control sites on the Louisiana shelf, were sampled in three consecutive seasons in 1978-79. The objectives of the biological data synthesis were to compare communities at control and platform sites with an emphasis on indicator species and to attempt to correlate biological parameters with various physical and chemical conditions related to offshore platforms. Problems including natural stress and anthropogenic contaminants from the Mississippi River were recognized and discussed.

The organic chemical analyses found low molecular weight hydrocarbons from several fold to approximately ten times open values. Sea water collected near two secondary platform sites in the second cruise had methane concentrations up to $24 \mathrm{mg} / \mathrm{l}$. 
High molecular weight hydrocarbons were always detected in sediment samples. Most of the measurements of tissue hydrocarbons were done on fish and macroepifauna. No unresolved complex mixtures of hydrocarbons were found in these tissues. The authors made some correlation between the amount of produced water and sand discharged and an increase in the transport of hydrocarbons to the benthos. However they suggest that the Mississippi river is the principle source of hydrocarbons in the study area.

It is strongly implied that hydrocarbons have a chronic sublethal effect on the fauna of the study area. Spies (1987) takes issue with this conclusion based on the fact that the authors extrapolated laboratory toxicity data to the hydrocarbons found in the study area. He asserts that most of the toxic effects described for marine organisms are from relatively low molecular weight aromatic hydrocarbons and that the sediment hydrocarbons found in the study were dominated by highly weathered mixtures.

\section{Buccaneer Gas and Oil Field Study (BGOF)}

The Buccaneer field consists of 18 structures of which 14 are satellite platforms, two are production platforms and two are crew quarters (see section 7). Harper et al. (1981) used data from a pilot study of the Buccaneer oil field to determine the possible impacts on the areal distribution of benthic biota, sediments, heavy metals, and hydrocarbons. The main source of hydrocarbon contamination came from discharge of about $600 \mathrm{bbl} /$ day of produced water which contained about $2 \mathrm{ppm}$ of extractable hydrocarbons. Oily sediments ( $306 \mathrm{ppm}$ ) were found adjacent to one of the production platforms, whereas mostly biogenic background levels of about $0.5 \mathrm{ppm}$ were found at all other stations. The macrobenthic faunal densities in the oiled bottom were reduced and the meiobenthos had an inverse ratio of nematodes to foraminifera compared with other stations. There was also evidence of a depressed fauna to the northeast of the field which may have been caused by an increased percentage of clay in the bottom or by some aspect of the production activities.

The study found that the platforms caused a decrease in macrobenthic abundance that was restricted to an area within $100 \mathrm{~m}$ of the platforms and possibly within $50 \mathrm{~m}$. It is not clear whether the effect was due to periodic contact with toxic substances in the bleedwater, substrate disturbance due to currents eddying around the platform leg and removing the substrate, or some other cause. There was no evidence that diversity was depressed around the platforms. Harper et al. (1981) found the area impacted to be relatively small when compared with the total area of the field. The surface sediments during certain seasons are in nearly continual motion over a somewhat more consolidated basement, and hydrocarbons reaching the benthos are quickly dispersed. It is therefore unclear whether the near platform effects were due to contamination or related to sediment variability (Spies, 1987). 


\section{Eugene Island (Neff et al., 1989)}

Neff et al. (1989) studied four oil-water separation platforms in the Gulf of Mexico off the central coast of Louisiana. They included an estuarine site in Terrebonne Bay at Lake Pelto Tank Battery No. 1 (section 11.2.3) and three offshore sites in 8 to 15 meters of water, Eugene Island, Block 105, Eugene Island, Block 120 and Ship Shoal, Block 114. Rates of produced water discharge from each platform were near the mean rate of discharge (1801 barrels/day) for the entire industry operation on the outer continental shelf of the Gulf of Mexico.

Bottom water and sediments in the vicinity of Ship Shoal, Block 114 contained little or no dissolved oxygen. As a result, the benthic fauna were depauperate throughout the area. Due to bad weather, an insufficient number of stations were sampled at Eugene Island, Block 120 to adequately characterize the local bottom environment. Therefore, of the offshore sites only Eugene Island, Block 105 was used for the detailed field study.

The benthic fauna are pioneer communities characteristic of disturbed marine and estuarine environments dominated by Mediomastus ambiseta. The dominant taxa at all stations were short lived, opportunistic species such as the polychaetes $M$. ambiseta and Streblospio benedicti and the bivalve mollusk Mulinia lateralis. The author hypothesized that this condition was caused by factors such as high suspended sediment loads attributable to the Mississippi River outflow and periodic bottom water hypoxia, neither of which are related to produced water discharges.

At Eugene Island Block 105, faunal density decreased with distance from the platform. However, diversity increased with distance. Benthic fauna at stations $20 \mathrm{~m}$ from the platform were all similar but differed from the fauna at stations further away.

The authors analyzed for sediment grain size for chemical and infaunal analysis, and concluded that grain size was the most important parameter contributing to gradients of benthic community structure around the platforms. Benthic communities within about $20 \mathrm{~m}$ of the platforms were influenced by sediment contamination probably derived from produced water discharges. Benthic communities located 100 to $1000 \mathrm{~m}$ from the platform exhibited no evidence of impacts attributable to platform discharges.

\subsection{Summary of Benthic Effects}

A number of studies have shown differences in benthic communities with distance from platforms discharging produced water. This was particularly true 
for coastal sites in contrast to offshore areas. Although some studies found correlations between the number of species and individuals and the chemical constituents in the near bottom waters or surficial sediments, the findings were site specific and not consistent across all studies. Some studies found little or no disturbance in the benthic communities. Information extracted from studies which found a correlation would be difficult for predicting effects because it is not clear whether the effect was due to periodic contact with toxic substrates in the produced water, substrate disturbance due to currents eddying around the platform leg and removing the substrate, or some other confounding factor (Harper et al., 1981).

\subsection{Application to Ecological Risk Assessment for Produced Water Discharges}

Site specific assessments of benthic effects from produced water discharges may have limited application for assessments at other sites. Available studies do, however, provide estimates of threshold levels for effects, and of community responses useful in the development of the problem formulation phase of an ecological risk assessment for produced water discharges. 


\section{SUMMARY -- DATA AND INFORMATION AVAILABLE FOR ECOLOGICAL RISK ASSESSMENTS FOR PRODUCED WATER DISCHARGES TO THE GULF OF MEXICO}

This report is part of a series of studies of the health and ecological risks from discharges of produced water to the Gulf of Mexico, supported by the United States Department of Energy (USDOE).

The report reviews important ecological risk assessment concepts and methods; describes important biological resources in the Gulf of Mexico of potential concern for produced water impacts; and summarizes data available to estimate exposure and effects of produced water discharges.

No impact analysis or ecological risk assessment is presented. Environmental assessments relating to subsets of produced water discharges in the Gulf of Mexico (e.g., discharges in open Louisiana bays, offshore discharges) are being developed using the data and information presented here, combined with data collected in a field study conducted by the USDOE and results of environmental transport and exposure modeling.

\section{Ecological Risk Assessment Concepts and Methods}

Approaches to ecological risk assessment were reviewed in the context of USEPA's proposed framework for ecological risk assessment. Methods for exposure assessment include application of transport and fate models, and approaches to the estimation of dose and internal exposure. Methods and data for the effects assessment phase in an ecological risk assessment include data from acute and chronic toxicity tests at the individual and population level, and methods to extrapolate effects between species, genera and from acute to chronic effects. Methods for risk characterization include comparing exposure and effects values or distributions, and the application of population and ecosystem models.

\section{Biological Resources In The Gulf Of Mexico}

A description of the important fisheries resources in the Gulf of Mexico was provided to support the problem formulation phase of ecological risk assessments and to identify appropriate endpoints for a specific analysis. Additional site or region specific data may be needed for a specific analysis, and species with important social value other than commercial or recreational uses should also be considered.

The Gulf of Mexico includes a wide variety of habitats for marine biota, both in the water column and on the seafloor. Important coastal ecosystems associated with the Gulf of Mexico include extensive wetlands and estuaries. Wetlands 
provide habitat for a great number and diversity of invertebrates, fish, reptiles, birds and mammals, and are important nursery grounds for many species of fish.

The commercial fishery resources of Texas and Louisiana are of national importance, and the Gulf of Mexico provides almost 20 percent of commercial fish landings in the United States (MMS, 1993). Marine recreational fishing in the Gulf of Mexico accounts for an estimated $\$ 769$ million in sales and employment for over 15,000 people (Sports Fishing Institute, 1987 as cited in MMS, 1993). Recreational fishing takes place from shore or within state waters, as well as offshore from private or charter boats.

Sportfishing in Louisiana and Texas is concentrated around oil and gas structures. Ditton and Auyong (1984) found heavy use of offshore platforms by private recreational fishing boats. Most private recreational boats were bottom fishing, with snapper and seatrout reported most frequently as the major target species. Croaker was reported as a major target species in the Delta Region.

\section{Platform Communities}

A description of the communities associated with coastal and offshore platforms in the Gulf of Mexico was given to support the problem formulation phase of an ecological risk assessment and describe the environment at risk. Community descriptions are also required in identifying assessment endpoints.

Oil and gas platform structures are colonized by microorganisms, algae, and sessile invertebrates that live attached to the structure and form the biofouling mat. These organisms provide food and habitat for many motile invertebrates and small fishes that live in close association with the biofouling mat. There is also a diverse assemblage of demersal and pelagic fishes associated with the platforms, some of which are residents. The composition of the biofouling community and assemblage of demersal and pelagic fishes associated with platforms varies with distance from shore, water depth, latitude and age of the platform (Gallaway and Lewbel, 1982).

\section{Endangered Species And Sensitive Ecosystems}

Descriptions of the major ecosystems and biota potentially at risk will support the problem formulation step in an ecological risk assessment. Endangered species and sensitive ecosystems represent unique social values and should be considered in identifying assessment endpoints.

Seven species of baleen whales have been reported in the Gulf of Mexico but are rare: the northern right whale, blue whale, fin whale, sei whale, Bryde's whale, minke whale and the humpback whale. Five of these species are listed as endangered. Twenty-five species of toothed whales and dolphins have been 
reported in the Gulf of Mexico. The sperm whale is the only one of the toothed whales and dolphins listed as endangered.

Endangered and threatened species of coastal and marine birds potentially impacted by produced water discharges include the brown pelican, bald eagle, arctic peregrine falcon, piping plover and the whooping crane. One species of fish listed as threatened is potentially affected by produced water discharges the Gulf Sturgeon (a subspecies of the Atlantic sturgeon).

Five species of marine turtles occur in the Gulf of Mexico, and all are listed as threatened or endangered (loggerhead turtle, green turtle, leatherback, hawksbill and Kemp's ridley).

Unique and sensitive biological resources of the Gulf of Mexico include coastal wetlands, the pinnacle trend live bottom features, topographic features inhabited by hard-bottom benthic communities, and deep water chemosynthetic benthic communities.

\section{Chemical/Physical Characterization Of Produced Water}

Data describing contaminant concentrations and discharge rates of produced water are needed to formulate the problem, identify potential impacts and describe the source term for an ecological risk assessment. Data presented here are limited and additional data derived from permit files and other sources may be needed in a site or area specific assessment.

Produced waters usually have high total dissolved solids (salinity) and total organic carbon, and are low in dissolved oxygen. Other components of potential concern include metals, dissolved and dispersed petroleum hydrocarbons, various treatment chemicals and radionuclides. Detected contaminants and contaminant concentrations in produced water vary widely, because the characteristics of the saline water and oil in the formation varies and because treatment methods and treatment efficiencies vary over time and space.

\section{Produced Water Toxicity}

Studies of the toxicity of produced water discharges can be used to assess potential effects on organisms. Problems with using these data include the importance of biocides in causing toxicity, and the change in toxicity that occurs with time and space. Site-specific toxicity tests are preferable to data derived from other sources.

Results of produced water bioassays conducted in the laboratory range from providing evidence of very low toxicities (Middleditch, 1984), to showing that produced water was highly toxic (Federal Register, 1992). This could be due to 
differences in the toxicity of the produced water, problems with protocols used in testing or the presence of biocides in some discharges.

\section{Bioaccumulation Of Major Toxic Components Of Produced Waters}

Data describing the bioaccumulation of produced water components can be used to formulate the problem, identify contaminants of potential concern and assess exposure. They can also be used to assess effects, although data relating body burdens to effects are limited. The BAF approach is commonly used in both human health and ecological risk assessments, but its reliability may be questionable.

The most direct estimates of bioaccumulation are derived from measurements of biotic and media specimens simultaneously obtained in the field. Although measurements on field-collected specimens are a preferred method for estimating site-specific bioaccumulation, they may be fiscally prohibitive (Lee, 1992). There is limited information on bioaccumulation of specific contaminants from produced waters in marine and estuarine organisms in the Gulf of Mexico. Because the data are limited, a modeling approach to estimating concentrations of organics, metals and radionuclides in animals is often used.

Only limited data are available for BAFs for organic and metals in saltwater organisms. BCFs available in the literature should be reviewed in the context of their relevance and appropriateness for application to a specific organism and specific circumstance. Generic values are often used in screening-models (Strenge and Peterson, 1989) and for organics may be calculated from octanolpartition coefficients. BCFs for some contaminants are available in the USEPA AQUIRE database (Russom et al., 1991).

\section{Toxicity of Chemical Components of Produced Water}

Data on the toxicity of produced water chemical components are needed to support an effects assessment. Limited data are available to describe toxicity to marine organisms native to the Gulf of Mexico, and extrapolating from laboratory studies performed on a standard test organisms adds uncertainty to an assessment.

A good place to start in developing the toxicity data needed in an analysis are the USEPA water quality criteria developed to protect saltwater animals as well as other values (USEPA, 1986). Additional data are available in the documents that support these criteria, in the open literature, and in electronic data bases. Another important concern in terms of potential impacts from produced water are effects on animals living on or in the sediment. There are limited data available to describe toxicities to these organisms, but sediment quality criteria have been derived for some contaminants. Limited data are also available to suggest a 
relationship between exposure to contaminants in water and sediment and genotoxic and histopathologic effects in fish.

\section{Radionuclide Effects}

Estimates of external and external dose and doses associated with individual and population effects are needed in an effects assessment for radionuclides discharged in produced water. Generic dose-factors can be used in a screening assessment to identify potential important contaminants and exposure pathways. There is uncertainty in the doses to marine organisms that may be expected to result in effects on individuals or populations, but estimates are available.

An aquatic organism may be irradiated externally by radionuclides in water and sediment, and internally by radionuclides taken into the body by ingestion or direct absorption. Most incorporated radionuclides are differentially distributed among the organs and tissues of the organism. Radium, for example, tends to accumulate in bone, skin and exoskeleton.

NCRP (1991) reviewed several models useful for estimating dose to aquatic animals. Models described include CRITR (Soldat et al., 1974), EXREM III, and BIORAD (Trubey and Kaye, 1973).

IAEA (1988) developed dose-rate factors that relate the radiation exposure to an organism to a unit concentration of the radionuclide in the water in which the organism lives. These dose rate factors are based on models using assumptions concerning the bioaccumulation factor, $K_{d}$ and the sizes and shapes of the animals (see IAEA, 1988). These factors may be useful for screening purposes.

IAEA (1976) presents a method for estimating the dose to aquatic organisms for radionuclides in water, sediment and accumulated in tissue.

Exposure to ionizing radiation can result in injury at the molecular, cellular and whole body levels. Most of the available studies of the effects of radiation on aquatic organisms are concerned with the induction of deterministic, somatic effects. These effects include increases in mortality and pathophysiological, developmental and reproductive effects. There is little information available concerning induction of cancer and genetic effects, although a few studies of stochastic genetic effects in organisms are available (Anderson and Harrison, 1986).

The National Council on Radiation Protection and Measurements recently reviewed the literature on the effects of ionizing radiation on aquatic organisms, and suggested reference levels that would protect aquatic populations (NCRP, 1991). NCRP (1991) suggested a reference dose rate to protect aquatic 
populations of $10 \mathrm{mGy} / \mathrm{d}$. NCRP also suggests a detailed assessment if an initial analysis results in estimated dose rate above $2.4 \mathrm{mGy} / \mathrm{d}$.

IAEA (1988) came to similar conclusions, but expressed their reference levels in terms of dose equivalent rather than absorbed dose. IAEA (1988) concluded that some somatic effects which would be eliminated by natural selection could occur between 0.004 and $1 \mathrm{mSv} / \mathrm{hr}(0.1-24 \mathrm{mSv} / \mathrm{d})$.

\section{Effects On Benthic Communities}

Site specific assessments of benthic effects from produced water discharges may have limited application for assessments at other sites. Available studies do, however, provide estimates of threshold levels for effects, and of community responses useful in the development of the problem formulation phase of an ecological risk assessment for produced water discharges.

Effects of platforms and platform discharges on benthic communities can vary from reductions in diversity and populations of particular species to increases in diversity and populations. This variation includes an increase in diversity at the expense of preexisting species, or an increase in numbers of particular species while total diversity declines. Some of these results are attributable to the introduction of a new structure (i.e., the platform), as well as the accumulation of contaminants in sediments. In the latter case relatively. low levels of contaminants may increase populations (hormesis) of opportunistic species that can either metabolically adapt to the contaminants, or compensate for toxic effects on particular life-stages by increases of more resistant stages in the populations.

A number of studies have shown differences in benthic communities with distance from platforms discharging produced water. This was particularly true for coastal sites in contrast to offshore areas. Although some studies found correlations between the number of species and individuals and the chemical constituents in the near bottom waters or surficial sediments, the findings were site specific and not consistent across all studies. Some studies had even found little or no disturbance in the benthic communities. Information extracted from studies which found a correlation would be difficult for predicting effects because it is not clear whether the effect was due to periodic contact with toxic substrates in the produced water, substrate disturbance due to currents eddying around the platform leg and removing the substrate, or some other confounding factor (Harper et al., 1981). 


\section{REFERENCES}

Anderson, S.L., and F.L. Harrison, 1986, Effects of Radiation on Aquatic Organisms and Radiobiological Methodologies for Effects Assessment, USEPA Report No. 520/1-85-016, United States Environmental Protection Agency, Washington, D.C.

Armstrong, H.W., K. Fucik, J.W. Anderson and J.M. Neff, 1977, Effects of Oilfield Brine Effluent on Benthic Organisms in Trinity Bay, Texas, American Petroleum Institute, Washington D.C.

ASTM, 1991, Annual Book of ASTM Standards, Sec. 11, Water and Environmental Technology, American Society for Testing and Materials, Philadelphia, PA.

Avanti Corporation, 1993, Ocean Discharge Criteria Evaluation for the NPDES General Permit For the Western Gulf of Mexico OCS, prepared for the United States Environmental Protection Agency, Water Management Division, Region VI.

Baan, R. A., M.J.S.T. Steenwinkel, P.T.M. van den Berg, R. Roggeband and J.H.M. van Delft, 1994, "Molecular Dosimetry of DNA Damage Induced by Polycyclic Aromatic Hydrocarbons; Relevance for Exposure Monitoring and Risk Assessment, "Human \& Experimental Toxicol. 13:880-887.

Barnthouse, L., 1993, "Population-Level Effects" in G.W. Suter, (ed.), Ecological Risk Assessment, Lewis Publishers, Boca Raton, FL.

Barnthouse, L.W., G.W. Suter, A.E. Rosen and J.J. Beauchamp, 1987, "Estimating Responses of Fish Populations to Toxic Contaminants", Environ. Toxicol. Chem. 6:811-824.

Barnthouse, L.W., G.W. Suter II, and A.E. Rosen, 1989, "Inferring Populationlevel Significance from Individual-level Effects: an Extrapolation from Fisheries Science to Ecotoxicology" pp. 289-300 in: G.W. Suter and M.A. Lewis (eds.) Aquatic Toxicology and Environmental Fate: 11th Volume, ASTM STP 1007, American Society for Testing and Materials, Philadelphia.

Barnthouse, L.W., G.W. Suter and A. Rosen, 1990, "Risks of Toxic Contaminants to Exploited Fish Populations: Influence on Life History, Data Uncertainty and Exploitation History", Environ. Toxicol. Chem. 9:297-311. 
Barnthouse, L.W., and J. Brown, 1994, "Conceptual Model Development" in: Ecological Risk Assessment Issue Papers, United States Environmental Protection Agency, Office of Research and Development, EPA630/R94/009.

Bartell, S.M., R.H. Gardner and R.V. O'Neil, 1988a, "An Integrated Fate and Effects Model for Estimation of Risk in Aquatic Systems", pp. 261-274, in: W.J. Mitsch, R.W. Bosserman and J.M. Klopatek, (eds.), Energy and Ecological Modeling, Elsevier, New York.

Bartell, S.M., R.H. Gardner and R.V. O'Neil, 1988b, "An Integrated Fate and Effects Model For Estimation of Risk in Aquatic Systems" Aquatic Toxicology and Hazard Assessment: Tenth Volume, ASTM STP Materials, Philadelphia.

Bartell, S.M., R.H. Gardner and R.V. O'Neill, 1992, Ecological Risk Estimation, Lewis Publishers, Boca Raton, FL.

Baumann, P.C. and J.C. Harshberger, 1995, "Decline in Liver Neoplasms in Wild Brown Bullhead Catfish After Coking Plant Closes, And Environmental PAHs Plummet", Environ. Health Perspectives 103:168-170.

Bender, M.E., D.J. Reish, and C.H. Ward, 1979, "Re-examination of the Offshore Ecology Investigation", pp 35-102 in: C.H. Ward, M.F. Bender and P.J. Reish (eds) The Offshore Ecology Investigation, Effects of Oil Drilling and Production in a Coastal Environmen, William March Rice University, Houston, TX.

Bert, T.M. and H.J. Humm, 1979, "Checklist of the Marine Algae on the Offshore Oil Platforms of Louisiana", in: C.H. Ward, M.E. Bender, and D.J. Reish, (eds.), The Offshore Ecology Investigation, Effects of Oil Drilling and Production in a Coastal Environment, Rice Univ. Stud. $65(4,5)$ pp. $437-$ 446.

Boehm, P.D. and J.W. Farrington, 1984, "Aspects of Polycyclic Aromatic Hydrocarbon Geochemistry of Recent Sediments in the Georges Bank Region," Environ. Sci. Technol. 18:804-845.

Boesh, D.F. and N.M. Rabalais, 1989a, Produced Waters in Sensitive Coastal Habitats, An Analysis of Impacts: Central Coastal Gulf of Mexico, OCS Report/MMS 89-0031, United States Department of the Interior, Minerals Management Service, Gulf of Mexico OCS Regional Office, New Orleans, LA. 
Boesh, D.F. and N.M. Rabalais, 1989b, Environmental Impact of Produced Water Discharges in Coastal Louisiana, Louisiana Universities Marine Consortium, Louisiana State University, A\&M College and Aero-Data Corporation, prepared for the Louisiana Division of the Mid-Continent Oil and Gas Association.

Bouchard, D.C., R.B. Ambrose, Jr., T.O. Barnwell, Jr., and D.W. Disney, 1995, "Environmental Modeling Software at the U.S. Environmental Protection Agency's Center for Exposure Assessment Modeling", in: G.E.G. Beroggi and W.A. Wallace (eds.), Computer Supported Risk Management, pp 321360, Kluwer Academic Publishers, Dordrecht, The Netherlands.

Brandsma, M.G., and Sauer, T.C., 1983a, "The OOC Model: Prediction of Short Term Fate of Drilling Mud in the Ocean, Part I: Model Description", in: Proceedings of the Workshop on an Evaluation of Effluent Dispersion and Fate Models for OCS Platforms, Santa Barbara, CA., February 7-10, 1983, Volume 2 pp 58-84, MBC Applied Environmental Sciences.

Brandsma, M.G., and Sauer, T.C., 1983b, "The OOC Model: Prediction of Short Term Fate of Drilling Mud in the Ocean, Part Il: Model Results", in: Proceedings of the Workshop on an Evaluation of Effluent Dispersion and Fate Models for OCS Platforms, Santa Barbara, CA., February 7-10, 1983, Volume 2, pp. 85-106, MBC Applied Environmental Sciences.

Brandsma, M.G., Smith, J.P., Reilly, J.O., and Ayers, R.C., Jr., and A.L. Holmquist, 1992, "Modeling Offshore Discharges of Produced Water", pp: 59-71, in: J.P. Ray and F.R. Engelhart, Produced Water, Plenum Press, New York.

Brooks, J.M., M.C. Kennicutt II, C.R. Fisher, S.A. Macko, K. Cole, J.J. Childress, R.R. Bidigare and R.D. Vetter, 1987, "Deep-sea Hydrocarbon Seep Communities: Evidence for Energy and Nutritional Carbon Sources", Science 238:1138-1142.

Burmaster, D.E., K.M. Thompson, E.A.C. Crouch, C.A. Menzie and T.E. McKone, 1990, "Monte Carlo Techniques for Quantitative Uncertainty Analysis in Public Health Risk Assessment", in: SUPERFUND '90, Proceedings of the 11th National Conference, November 26-28, 1990.

Calabrese, E.J. and L.A. Baldwin, 1993, Performing Ecological Risk Assessments, Lewis Publishers, Boca Raton, FL. 
Capuzzo, 1987, "Biological Effects of Petroleum Hydrocarbons: Assessments From Experimental Results", pp. 343-420, in: D.F. Boesch and N.N. Rabalais, eds., Long-Term Environmental Effects of Offshore Oil and Gas Development, Elsevier Applied science, New York

Cherry, R.D., and L.V. Shannon, 1974, "The Alpha Radioactivity of Marine Organisms", Atomic Energy Review, 12:3-45.

Continental Shelf Associates, 1991, Measurements of Naturally Occurring Radioactive Materials (NORM) at Three Produced Water Outfalls, Continental Shelf Associates, Inc., Jupiter, Florida, prepared for MidContinent Oil and Gas Association, Baton Rouge, LA.

Continental Shelf Associates, 1992a, Mississippi-Alabama Shelf Pinnacle Trend Habitat Mapping Study, U.S. Department of the Interior, Minerals Management Service, Gulf of Mexico OCS Regional Office, New Orleans, LA, OCS Study/MMS 92-0026,

Continental Shelf Associates, 1992b, Measurements of Naturally Occurring Radioactive Material at Two Offshore Production Platforms in the Northern Gulf of Mexico, Preliminary Data Report, prepared for the American Petroleum Institute, Washington, D.C.

Cothern, 1988, "Uncertainties in Quantitative Risk Assessments - Two Examples: Trichloroethylene and Radon in Drinking Water", pp. 159-180, in: Advances in Modern Toxicology Vol 15, Risk Assessment and Risk Management of Industrial and Environmental Chemicals, Princeton Scientific Publishing Company, New Jersey.

Darnell, R.M., and N.W. Phillips, 1988, "Conceptual Modeling" in: Phillips, N.W. and Bela M. James, eds., Offshore Texas and Louisiana Marine Ecosystems Data Synthesis, Volume II: Synthesis Report, pp 353-412. U.S. Department of the Interior, Minerals Management Service, Gulf of Mexico OCS Regional Office, New Orleans, LA. OCS study. MMS 88-0067.

Darnell, R.M., and D.J. Schmidly, 1988, "Marine Biology" in: Phillips, N.W. and Bela M. James, eds., Offshore Texas and Louisiana Marine Ecosystems Data Synthesis, Volume II: Synthesis Report, pp. 203-325 . U.S. Department of the Interior, Minerals Management Service, Gulf of Mexico OCS Regional Office, New Orieans, LA, OCS Study. MMS 88-0067.

Defenbaugh, R.E., 1976, A Study of the Benthic Macroinvertebrates of the Continental Shelf of the Northern Gulf of Mexico, Ph.D. Dissertation, Texas A\&M University, College Station, TX, (as cited in Darnell and Schmidly, 1988). 
Ditton, R.B. and J. Auyong, 1984, Fishing Offshore Platforms, Central Gulf of Mexico, An Analysis of Recreational and Commercial Fishing Use at 164 Major Offshore Petroleum Structures, Minerals Management Service, Metairie, LA, MMS-84-0006.

Doneker, R.L. and G.H. Jirka, 1990, Expert System for Hydrodynamic Mixing Zone Analysis of Conventional and Toxic Submerged Single Port Discharges (CORMIX 1), EPA600/3-90/012, United States Environmental Protection Agency, Athens, GA.

Emlen J.M., 1989, "Terrestrial Population Models For Ecological Risk Assessment: A State-Of The Art Review", Environ. Toxicol. Chem. 8:831842.

E.V.S. Consultants, 1990, Sediment Toxicity Evaluation, API Publication 4501, American Petroleum Institute, Washington, D.C.

Federal Register, 1987, "Toxic Substances Control Act Test Guidelines: Proposed Rule", Federal Register 52:36334-36371.

Federal Register, 1992, "Environmental Protection Agency, Final NPDES General Permit for the Western Gulf of Mexico Outer Continental Shelf", Federal Register 58:224:54642-54671.

Federal Register, 1993, "Environmental Protection Agency, Oil and Gas Extraction Point Source Category; Offshore Subcategory Effluent Limitations Guidelines and New Source Performance Standards", 40 CFR Part 435, Federal Register 58:41:12454-12512.

Fotheringham, N., 1981, Effects of Offshore Oil Field Structures on the Biotic Environment: Platform Fouling Community in: B.S. Middleditch, (ed.), Environmental Effects of Offshore Oil Production, The Buccaneer Gas and Oil Field Study, Plenum Press, New York, pp. 179-208.

Franke, C., G. Studinger, G. Berger, S. Böhling, U. Bruckmann, D. CohorsFresenborg and U. Jöhncke, 1994, "The assessment of Bioaccumulation", Chemosphere 29:1501-1514.

Franz, D. R. and J. T. Tanacredi, 1992, "Secondary Production of the Amphipod Ampelisca abdita Mills and its Importance in the Diet of Juvenile Winter Flounder (Pleuronectes americana) in Jamaica Bay, New York, Estuaries 15:193-203. 
Fucik, K.W. and I.T. Show, 1981, "Environmental Synthesis Using an Ecosystems Model", in: B.S. Middleditch, ed., Environmental Effects of Offshore Oil Production, The Buccaneer Gas and Oil Field Study, Plenum Press, New York, pp. 320-353.

Gallaway. B.J., 1981, An Ecosystem Analysis of Oil and Gas Development on the Texas-Louisiana Continental Shelf, U.S. Fish and Wildlife Service, Office of Biological Services, Washington, D.C., FWS/OBS-81/27.

Gallaway, B.J. and F.J. Margraf, 1979, Simulation Modeling of Biological Communities Associated With A Production Platform in Buccaneer Gas and Oil Field, Annual Report to the National Marine Fisheries Service, Galveston, TX.

Gallaway, B.J., L.R. Martin, R.L. Howard, G.S. Bowland and G.S. Dennis, 1981a, "Effects on Artificial Reef and Demersal Fish and Macrocrustacean Communities" in: B.S. Middleditch, ed., Environmental Effects of Offshore Oil Production, The Buccaneer Gas and Oil Field Study, Plenum Press, New York, pp. 237-299.

Gallaway, B.J., M.F. Johnson, L.R. Martin, F.J. Margraf, G.S. Lewbel, R.L. Howard and G.S. Bowland, 1981b, "The Artificial Reef Studies, Vol II.", in: C.A. Bedinger, Jr., ed., Ecological Investigations of Petroleum Production Platforms in the Central Gulf of Mexico, Report by the Southwest Research Institute to the Bureau of Land Management, New Orleans, LA., Contract No. AA551-CT8-17.

Gallaway, B.J. and G.S. Lewbel, 1982, The Ecology of Petroleum Platforms in the Northwestern Gulf of Mexico: A Community Profile, U.S. Fish and Wildife Service, Office of Biological Services, Washington, D.C., FWS/OBS-82/27, Bureau of Land Management, Gulf of Mexico OCS Regional Office, Open-File Report 82-03.

George R.Y. and P.J. Thomas, 1979, "Biofouling Community Dynamics in Louisiana Shelf Oil Platforms in the Gulf of Mexico", in: C.H. Ward, M.E. Mender and D.J. Reish, (eds.), The Offshore Ecology Investigation, Effects of Oil Drilling and Production in a Coastal Environment, Rice Univ. Stud. vol. 65 , Nos. 4,5 , Houston, TX.

Goksøyr, A., J. Beyer, A. M. Husoy, H. E. Larsen, K. Westrheim and S. Wilhelmsen, 1994, "Accumulation and Effects of Aromatic and Chlorinated Hydrocarbons in Juvenile Atlantic cod (Gadus morhua) Caged in a Polluted Fjord (Sørjorden, Norway), Aquatic Toxicology 29:21-35. 
Harper, D.E. and D.C. Potts, 1981, "Distribution and Abundance of Macrobenthic and Meiobenthic Organisms" pp 133-177 in B.S. Middleditch (ed.)

Environmental Effects of Offshore Oil Production, the Buccaneer Gas and Oil Field Study. Plenum Press, New York.

Hellou, J., 1995, "Polycyclic Aromatic Hydrocarbons in Marine Mammals, Finfish and Molluscs", in: Heinz and Beyer, eds., Interpreting Environmental Contaminants in Animal Tissues, Lewis Publishers, Boca Raton, In Press.

Hellou, J., J. F. Payne, C. Upshall, L.L. Fancey and C. Hamilton, 1994, "Bioaccumulation of Aromatic Hydrocarbons From Sediments: A DoseResponse Study with Flounder (Pseudopleuronectes americanus)", Archives of Environmental Contamination and Toxicology 27:477-485.

Hellou, J., D. MacKay and B. Fowler, 1995, "Bioaccumulation of Polycyclic Aromatic Compounds from Sediments to Muscle of Finfish", Environ. Sci. Technol. 29:25555-2560.

Hellou, J. and C. Upshall, 1994, "Monocyclic Aromatic Hydrocarbons in Bile of Flounder Exposed to a Petroleum Oil", Intern. J. Environ. Analyt. Chem. 60:101-111

Heillou, J. and C. Upshall, 1995, "Fate of Hydrocarbons in Pseudopleuronectes americanus exposed to Hibernia Crude Oil", Canad. Technol. Report Fish. Aquat. Sci., In Press.

Holcombe, G.W., G.L. Phipps and G.D. Veith, 1988, "Use of Acute Lethality Tests to Estimate Safe Chronic Concentrations of Chemicals in Initial Ecological Risk Assessments", pp. 442-467, in: G.W. Suter II and M. Lewis, (eds.), Aquatic Toxicity and Hazard Assessment: Eleventh Symposium, American Society for Testing and Materials, Philadelphia, PA.

IAEA, 1976, Effects of lonizing Radiation on Aquatic Organisms and Ecosystems, Technical Report Series No. 172, International Atomic Energy Agency, Vienna.

IAEA, 1982, Generic Models and Parameters for Assessing the Environmental Transfer of Radionuclides from Routine Releases, Safety Series No. 57, Procedures and Data, International Atomic Energy Agency, Vienna.

IAEA, 1985, Sediment Kds and Concentration Factors for Radionuclides in the Marine Environment, Technical Report Series No. 247, International Atomic Energy Agency, Vienna. 
IAEA, 1988, Assessing the Impact of Deep Sea Disposal of Low Level Radioactive Waste on Living Marine Resources, Technical Reports Series No. 288, International Atomic Energy Agency, Vienna.

ICRP, 1979. Radionuclide Release Into the Environment: Assessment of Doses to Man. ICRP Publication 29. International Commission on Radiological Protection, Pergamon Press, New York NY.

ICRP, 1991, "1990 Recommendations of the International Commission on Radiological Protection", Publication 60, Annals of the ICRP, 21:1-3, Pergamon Press, Oxford.

Jackson, W.B., 1979, (ed) Environmental Assessment of an Active Oil Field in the Northwest Gulf of Mexico 1977-1978, Volume II Data Management and Biological Investigation, U.S. Department of Commerce PB80-165970.

Jenkins, K.D. and A. Gillam, 1991, Evaluation of the AET as a Basis for Setting Sediment Quality Criteria, Health and Environmental Sciences Department, API Publication Number 1, American Petroleum Institute, Washington, DC.

Johnson, L. L. and J. T. Landahl, 1994, "Chemical Contaminants, Liver-disease, and Mortality-rates in English Sole", Ecological Applications 4:59 -68.

Johnson, L. L., C. M. Stehr, O.P. Olson, M.S. Myers, S.M. Pierce, C.A. Wigren, B.B. McCain and U. Varanasi, 1993, "Chemical Contaminants and Hepatic Lesions in Winter Flounder (Pleuronectes americanus) From the Northeast Coast of the United States", Environmental Science and Technology 27:2759-2771.

Kooijman, S.A.L.M., 1983a, "Parametric Analysis of Population Growth in Bioassays", Water Res. 17:527-538.

Kooijman, S.A.L.M., 1983b, "Statistical Aspects of the Determination of Mortality Rates in Bioassays". Water Res. 17-749-759.

Lamberson, J. O., T. H. DeWitt, and R.C. Swartz, 1992, "Assessment of Sediment Toxicity to Marine Benthos", Chapter 9 in : G. A. Burton Jr., (ed), Sediment Toxicity Assessment, Lewis Publishers, Boca Raton, pp. 183 211.

Lee, H., II, 1992, "Models, Muddles, and Mud: Predicting Bioaccumulation of Sediment-Associated Pollutants", Chapter 12 in : G. A. Burton Jr., (ed.), Sediment Toxicity Assessment, Lewis Publishers, Boca Raton, pp. 267 293. 
Linton, T.L., 1988, "Socioeconomics" in: Phillips, N.W. and Bela M. James, (eds.), Offshore Texas and Louisiana Marine Ecosystems Data Synthesis, Volume II: Synthesis Report, pp. 327-351, U.S. Department of the Interior, Minerals Management Service, Gulf of Mexico OCS Regional Office, New Orleans, LA. OCS Study. MMS 88-0067.

Loevinger, R., J.G. Holt and G.J. Hine, 1956. "Internally Administered Radioisotopes", Chapter 7, In: Radiation Dosimetry, G.J. Hine and G.L. Brownell, (eds.), Academic Press, New York.

Long, E. R., D. D. Macdonald, S. L. Smith, F. D. Calder, 1995, "Incidence of Adverse Biological Effects Within Ranges of Chemical Concentrations in Marine and Estuarine Sediments", Environmental Management 19:81-97.

Long, E.R., and L.G. Morgan, 1990, The Potential for Biological Effects of Sediment-sorbed Contaminants Tested in the National Status and Trends Program, NOAA Tech. Memo. NOS OMA 52, U.S. National Oceanic and Atmospheric Administration, Seattle, WA.

Mackay, D., and S. Paterson, 1993, "Mathematical Models of Transport and Fate", in: G.W. Suter, (ed.), Ecological Risk Assessment, Lewis Publishers, Boca Raton, FL.

Matthews, T. D., 1994, "Contaminants in Recreationally Important Estuarine Finfish from South Carolina", Bull. Environ. Contam. Toxicol, 53:412-419.

Mayer, F.L., C.H. Deans and A.G. Smith, 1987, Inter-taxa Correlations for Toxicity to Aquatic Organisms" EPA/600/X-87/332, United States Environmental Protection Agency, Environmental Research Laboratory, Gulf Breeze, Florida.

Meinhold, A.F., and L.D. Hamilton, 1992, "Radium Concentration Factors and Their Use in Health and Environmental Risk Assessment" ", pp. 293-302, in: Produced Water, J.P. Ray and F.R. Engelhart, eds., Plenum Press, New York, pp. 293-302.

Meinhold, A.F., L.D. Hamilton, S. Holtzman and S.L. Baxter, 1993. Human Health Risk Assessment for Radium Discharged in Produced Waters Offshore: Phase II, Brookhaven National Laboratory, Upton, NY, BNL60107. 
Menzies, R.J., J.P. Morgan, C.H. Oppenheimer, S.Z. El-Sayed and JM. Sharp, 1979, "Design of the Offshore Ecology Investigation", pp. 19-32, in: C.H. Ward, M.E. Bender and D.J. Reish, (eds), The Offshore Ecology Investigation: Effects of Oil Drilling and Production in a Coastal Environment, Rice Univ. Stud. Vol. 65, No. 4,5, Houston, TX.

Middleditch, B.S., 1981, (ed.), Environmental Effects of Offshore Oil Production, The Buccaneer Gas and Oil Field Study, Plenum Press, New York

Middleditch, B.S., 1984, Ecological Effects of Produced Water Discharges From Offshore Oil and Gas Production Platforms, Final Report on API Project No. 248, American Petroleum Institute, Washington, D.C.

MMS, 1990, Gulf of Mexico Sales 131, 135, and 137: Central Western and Eastern Planning Areas, Final Environmental Impact Statement, Volumes I, II, United States Department of the Interior, Minerals Management Service, New Orleans, LA, OCS EIS/EA MMS 90-0042.

MMS, 1993, Gulf of Mexico Sales 147 and 150: Central and Western Planning Areas, Final Environmental Impact Statement, Volumes I, II, United States Department of the Interior, Minerals Management Service, New Orleans, LA, OCS EJS/EA MMS 93-0065.

MMS, 1994, Gulf of Mexico Sales 152 and 155: Central and Western Planning Areas, Draft Environmental Impact Statement, Volumes I, II, United States Department of the Interior, Minerals Management Service, New Orleans, LA, OCS EIS/EA MMS 94-0019.

Moore, M. J. and J. J. Stegeman, 1994, "Hepatic Neoplasms in Winter Flounder Pleuronectes americanus from Boston Harbor, Massachusetts, USA", Diseases Of Aquatic Organisms 20:33-48.

Moskowitz, P.D., R.R. Pardi, M.P. DePhillips, A.F. Meinhold and B. Irla., 1995, "Computer Models Used to Support Cleanup Decision Making at Hazardous and Radioactive Waste Sites", in: G.E.G. Beroggi and W.A. Wallace (eds.), Computer Supported Risk Management, pp 275-320, Kluwer Academic Publishers, Dordrecht, The Netherlands.

Myers, M. S., J. T. Landahl, M. M. Krahn, B. B. Mccain, 1991, Relationships Between Hepatic Neoplasms and Related Lesions and Exposure to Toxic Chemicals in Marine Fish from the United States West Coast", Environmental Health Perspectives 90:7-15. 
Napier, B.A., R.L. Roswell, W.E. Kennedy, Jr., and D.L. Strenge, 1980, Assessment of Effectiveness of Geologic Isolation Systems: ARRRG and FOOD: Computer Programs for Calculating Radiation Dose to Man from Radionuclides in the Environment, PNL-3180, Pacific Northwest Laboratory, Richland, WA.

NCRP, 1991, Effects of lonizing Radiation on Aquatic Organisms, NCRP Report No. 109, National Council on Radiation Protection and Measurements, Bethesda, MD.

Neff, J., M.,1987, "Biological Effects of Drilling Fluids, Drill Cuttings and Produced Waters" pp. 469-538, in: D.F. Boesch and N.N. Rabalais, eds., Long-Term Environmental Effects of Offshore Oil and Gas Development, Elsevier Applied Science, New York.

Neff, J.M., B.A. Cox, D. Dixit and J.W. Anderson, 1976, "Accumulation and Release of Petroleum-derived Aromatic Hydrocarbons by Four Species of Marine Animals", Mar. Biol. 38:279-289.

Neff, J., M., N.N. Rabalais and D.F. Boesch, 1987, "Offshore Oil and Gas Development Activities Potentially Causing Long-Term Environmental Effects" pp. 149-173, in: D.F. Boesch and N.N. Rabalais, eds., Long-Term Environmental Effects of Offshore Oil and Gas Development, Elsevier Applied Science, New York.

Neff, J.M., T.C. Sauer and N. Maciolek, 1989, Fate and Effects of Produced Water Discharges in Nearshore Marine Waters, API Publication NO. 4472, American Petroleum Institute, Washington, D.C.

NRC, 1983, Risk Assessment in the Federal Government: Managing the Process, National Research Council, National Academy Press, Washington, D.C.

O'Neil, R.V., R.H. Gardner, L.W. Barnthouse, G.W. Suter, S.G. Hildebrand and C.W. Gehrs, 1982, "Ecosystem Risk Analysis: A New Methodology", Environ. Toxicol. Chem. 1:167-177.

O'Neil, R.V., S.M. Bartell and R.H. Gardner, 1983, "Patterns of Toxicological Effects in Ecosystems: A Modeling Study", Environ. Toxicol. Chem. 2:451461. 
O'Reilly, J.E., Sauer, T.C., Ayers, R.C. Jr., Brandsma, M.G., and Meek, R., 1988, "Field Verification of the OOC Mud Discharge Model", in: Drilling Wastes, Engelhardt, F.R., Ray, J.P., and Gillam A.H., eds. Proceedings of the 1988 International Conference on Drilling Wastes, Calgary, Alberta, Canada, April 5-8, .1988, pp. 647-666.

Paustenbach, D.J., D.M. Meyer, P.J. Sheenan and V. Lau, 1991, "An Assessment and Quantitative Uncertainty Analysis of the Health Risks to Workers Exposed to Chromium-Contaminated Soils", Toxicol. Indust. Health 7:159-196.

Power, E. A. and P. M. Chapman, 1992; "Assessing Sediment Quality", Chapter 1, pp. 1-18, in : G.A. Burton Jr., ed, Sediment Toxicity Assessment, Lewis Publishers, Boca Raton,

Rabalais, N.N., B. McKee, D.J. Reed and J.C. Means, 1991, Fate and Effects of Nearshore Discharges of OCS Produced Waters, Volume II, Technical Report, OCS Study/MMS 91-0005, U.S. Department of Interior, Minerals Management Service, Gulf of Mexico OCS Regional Office, New Orleans, LA.

Reggio, V.C. Jr., Rigs-to-Reefs, 1987, Minerals Management Service, Gulf of Mexico OCS, Regional Office, New Orleans, LA., OCS Report, MMS 870015.

Rezak, R. T.J. Bright and D.W. McGrail, 1985, Reefs and Banks of the Northwestern Gulf of Mexico: Their Geological, Biological and Physical Dynamics, John Wiley and Sons, New York, NY.

Rose, C.D. and T.J. Ward, 1981, "Acute Toxicity and Aquatic Hazard Associated with Discharged Formation Water" pp 301-327 in: B.S. Middleditch (ed.) Environmental Effects of Offshore Oil Production, the Buccaneer Gas and Oil Field Study. Plenum Press, New York.

Russom, C. L. and E. B. Anderson, 1991, "Aster in Integration of the Aquire Data Base and the QSAR System For Use in Ecological Risk Assessments", Science Of The Total Environment 109:667-670.

SAIC, 1991, Produced Water Variability Factors and Filtration Efficiency Assessments From the Three Facility Oil and Gas Study, prepared for the Industrial Technology Division, United States Environmental Protection Agency, Washington, D.C. 
Sanders, H.L., 1981, "Environmental Effects Of Oil in the Marine Environment", In: Safety and Offshore Oil: Background Papers of the Committee on Assessment of Safety in OCS Activities, National Research Council, National Academy Press, Washington, D.C.

St. Pé, 1990, An Assessment of Produced Water Impacts to Low-Energy, Brackish Water Systems in Southeast Louisiana, Louisiana Department of Environmental Quality, Water Pollution Control Division, Baton Rouge, LA.

Schaefer, E.W. Jr., W.A. Bowles, Jr., and J. Hurlbet, 1983, "The Acute Oral Toxicity, Repellancy and Hazard Potential of 933 Chemicals to House and Deer Mice", Arch. Environm. Contam. Toxicol. 12:355.

Shinn, E.A., 1974, "Oil Structures as Artificial Reefs", pp. 91-96 in: L. Colunga and R. Stone, (eds.), Proceedings of an International Conference on Artificial Reefs, Center for Marine Resources, Texas A\&M University, College Station, (as cited by Gallaway and Lewbel, 1982).

Sloff, W., J.A. M. van Oers and D. de Zwart, 1986, "Margins of Uncertainty in Ecotoxicological Hazard Assessment", Environ. Toxicol. Chem. 5:841-852.

Smith, E., and H. Shugart, 1994, "Issue Paper on Uncertainty in Ecological Risk Assessment", in: Ecological Risk Assessment Issue Papers, Office of Research and Development, Risk Assessment Forum, United States Environmental Protection Agency, Washington, D.C., EPA/630/R-94/009.

Soldat, J.K., N.M. Robinson and D.A. Baker, 1974, Models and Computer Codes For Evaluating Environmental Radiation Doses, BNWL-1754, Battelle Pacific Northwest Laboratories, Richland, WA.

Spies, R.B., 1987, "The Biological effects of Petroleum Hydrocarbons in the Sea: Assessments from the Field and Microcosms" pp 411-454 in: D.F. Boesch and N.N. Rabalais, eds., Long-Term Environmental Effects of Offshore Oil and Gas Development, Elsevier Applied Science, New York.

Sports Fishing Institute, 1987, Number of Paid Fishing License Holders, License Sales, and Cost to Fishermen, Fiscal Year 1986, Bulletin No. 387, Washington, D.C. (as cited in MMS, 1993).

Stanley, D.R. and C.A. Wilson, 1990, "A Fishing-Dependent Based Study of Fish Species Composition and Associated Catch Rates Around Oil and Gas Structures Off Louisiana", U.S. Fishery Bulletin 88:719-730.

Steimle \& Associates, 1992, Fate and Effects of Radionuclides, Data Report, prepared for the American Petroleum Institute, Washington, D.C. 
Stephan, C.E., 1977, "Methods for Calculating an LC $_{50}$ ", pp. 65-84, in: F.L. Mayer and J.L. Hamelink, (eds.), Aquatic Toxicology and Hazard Assessment, ASTM STP 634, American Society for Testing and Materials, Philadelphia.

Stephenson, M.T., 1992, “A Survey of Produced Water Studies", pp. 1-12, in: Produced Water, J.P. Ray and F.R. Engelhart, (eds.), Plenum Press, New York.

Stephenson, M.T. and I.R. Supernaw, 1990, Offshore Operators Committee 44 Platform Study, Radionuclide Analysis Results, Texaco, Inc.

Strenge, D.L., R.A. Peloquin and G. Whelan, 1986, LADTAP / - Technical Reference and User Guide, NUREG/CR-4013, United States Nuclear Regulatory Commission, Washington, D.C.

Strenge, D.L. and S.R. Peterson, 1989, Chemical Data Bases for the Multimedia Environmental Pollutant Assessment System (MEPAS): Version 1, PNL7145, Pacific Northwest Laboratory, Richland, WA.

Suter, G. W. , 1993a, "Defining the Field" in G.W. Suter, (ed.), Ecological Risk Assessment,-'Lewis Publishers, Boca Raton, FL.

Suter, G.W., 1993b, (ed), Ecological Risk Assessment, Lewis Publishers, Boca Raton, FL.

Suter, G. W. , 1993c, "Predictive Risk Assessments of Chemicals" in: G.W. Suter, (ed)., Ecological Risk Assessment, Lewis Publishers, Boca Raton, FL.

Suter, G. W. , 1993d, "Organism-Level Effects” in: G.W. Suter, (ed.) Ecological Risk Assessment, Lewis Publishers, Boca Raton, FL.

Suter, G.W. and L.W. Barnthouse, 1993, "Assessment Concepts" in: G.W. Suter, (ed.), Ecological Risk Assessment, Lewis Publishers, Boca Raton, FL.

Suter, G. W. , and S. Bartell, 1993, "Ecosystem-Level Effects" in G.W. Suter, (ed.), Ecological Risk Assessment, Lewis Publishers, Boca Raton, FL.

Suter, G. W. II and A.E. Rosen, 1988, "Comparative Toxicology for Risk Assessment of Marine Fishes and Crustaceans", Environ. Sci. Technol. 22:548-556. 
Suter, G.W. III, D.S. Vaughan and R.H. Gardner, 1983, "Risk Assessment by Analysis of Extrapolation Error, a Demonstration for Effects of Pollutants on Fish", Environ. Toxicol: and Chemistry 2:369-378.

Suter, G. W. II, A.E. Rosen and E. Linder, 1986, "Analysis of Extrapolation Error," pp. 49-81 in: L.W. Barnthouse and G.W. Suter, (eds.) User's Manual for Ecological Risk Assessment, ORNL-6251, Oak Ridge National Laboratory, Oak Ridge TN.

Suter, G.W. II, A.E. Rosen, G. Linder and D.F. Parkhurst, 1987, "Endpoints for Responses of Fish to Chronic Toxic Exposures", Environ. Toxicol. Chem. 6:793-809.

Suter, G.W., J. Gillette and S. Norton, 1994, "Issue Paper on Characterization of Exposure" in: Ecological Risk Assessment Issue Papers, Office of Research and Development, Risk Assessment Forum, United States Environmental Protection Agency, Washington, D.C., EPAV630/R-94/009.

Templeton, W.L., 1980, "Ecological Effects of Transuranics in the Marine Environment", In: Radiation Effects on Aquatic Organisms, N. Egami, (ed.), Park Press, Baltimore. pp 3-12.

Templeton, W.L., Nakatani, R.E. and E.E. Held, 1971. "Radiation Effects", In: Radioactivity in the Marine Environment, National Academy of Sciences, Washington D.C. pp. 223-240.

Thompson, S.E., Burton, C.A., Quinn, D.J., and Ng, Y.C., 1972, Concentration Factors of Chemical Elements in Edible Aquatic Organisms, Lawrence Livermore National Laboratory, University of California, Report UCRL50564, Revision 1.

Trubey, D.K., and S.V. Kaye, 1973, The EXREM III Computer Code For Estimating External Radiation Doses to Populations From Environmental Releases, ORNL-TM-4322, Oak Ridge National Laboratory, Oak Ridge, Tennessee

USDOC, 1991, Marine Recreational Fishery Survey, Atlantic and Gulf Coasts, 1987-1989, U.S. Department of Commerce, National Oceanic and Atmospheric Administration, National Marine Fisheries Service, Silver Spring, MD. Current Fisheries Statistics No. 8904.

USDOC, 1992, Fisheries of the United States 1991, U.S. Department of Commerce, National Oceanic and Atmospheric Administration, National Marine Fisheries Service, Silver Spring MD. Current Fishery Statistics No. 9100. 
USEPA, 1980, Ambient Water Quality Document for Polynuclear Aromatic Hydrocarbons, Prepared by the Office of Health and Environmental Assessment, Environmental Criteria and Assessment Office, Cincinnati, $\mathrm{OH}$ for the Office of Water Regulations and Standards, United States Environmental Protection Agency, Washington, D.C. EPA 440/5-80-069, NTIS PB 81-117806.

USEPA, 1982, Guidelines and Support Documents for Environmental Effects Testing, United States Environmental Protection Agency, Washington, D.C.

USEPA, 1985, Methods for Measuring the Acute Toxicity of Effluents to Freshwater and Marine Organisms, (Third Edition) EPA600/4-85/013, United States Environmental Protection Agency, Washington, D.C.

USEPA, 1986, Quality Criteria for Water, Office of Water Regulations and Standards, United States Environmental Protection Agency, Washington, D.C. EPA/440/5-86/001, NTIS PB87-226759.

USEPA, 1989a, Risk Assessment Guidance for Superfund, Volume I, Human Health Evaluation Manual (Part A) Interim Final, Office of Emergency and Remedial Response, EPA1540/1-89/002, United States Environmental Protection Agency, Washington, D.C.

USEPA, 1989b, Assessing Human Health Risks from Chemically Contaminated Fish and Shellfish: A Guidance Manual, Office of Marine and Estuarine Protection (WH-558f) and Office of Water Regulation and Standards (WH552), United States Environmental Protection Agency, Washington, D.C.

USEPA, 1991, Drinking Water Criteria Document for Polycyclic Aromatic Hydrocarbons (PAHS), prepared by the Office of Health and Environmental Assessment, Office of Environmental Criteria and Assessment, for the Office of Water, United States Environmental Protection Agency, Washington, D.C., ECAO-CIN-DO1O, NTIS PB92-173459.

USEPA, 1992, Framework for Ecological Risk Assessment, Office of Research and Development, United States Environmental Protection Agency, Washington, D.C., EPA/630/R-92/001. 
USEPA, 1993a, Wildlife Exposure Factors Handbook, Vol I, Vol II: Appendix: Literature Review Database, Office of Research and Development, United States Environmental Protection Agency, Washington, D.C., EPA600/R93/187a,b.

USEPA, 1993b, Produced Water Radioactivity Study, Final Draft, Office of Science and Technology, Office of Water, United States Environmental Protection Agency, Washington, D.C.

USEPA, 1993c, Regulatory Impact Analysis of Final Effluent Guidelines and Standards for the Offshore Oil and Gas Industry, Office of Water, United States Environmental Protection Agency, Washington, D.C., EPA 821-R93-002.

USEPA, 1993d, Development Document for Effluent Limitations Guidelines and New Source Performance Standards for the Offshore Subcategory of the Oil and Gas Extraction Point Source Category, Final, United States Environmental Protection Agency, Washington, D.C., EPA 821-R-93-003.

USEPA, 1994, Ecological Risk Assessment Issue Papers, Office of Research and Development, Risk Assessment Forum, United States Environmental Protection Agency, Washington, D.C., EPAV630/R-94/009.

USFDA, 1992, Action Levels for Poisons or Deleterious Substances in Human Food and Animal Feed, US Food and Drug Administration, Department of Health and Human Services, Washington, D.C.

van der Oost, R., F. J. van Schooten, 1994, "Bioaccumulation, Biotransformation and DNA Binding of PAHs in Feral Eel (Anguilla anguilla) Exposed to Polluted Sediments: a Field Survey," Environmental Toxicology And Chemistry 13:859-870.

Wiegart, R. and S. Bartell, 1994, "Issue Paper on Risk Integration Methods", in: Ecological Risk Assessment Issue Papers, Office of Research and Development, Risk Assessment Forum, United States Environmental Protection Agency, Washington, D.C., EPA630/R-94/009.

Witzig, J.F., 1986, "Rig Fishing in the Gulf of Mexico-- 1984 Marine Recreational Fishing Results", in: Proceedings if the Sixth Annual Gulf of Mexico Information Transfer Meeting, Minerals Management Service, New Orleans, LA, MMS-86-0073. 
Woodhead, D.S., 1984, "Contamination Due to Radioactive Materials" in: O. Kinne, (ed)., Marine Ecology, Vol V, Part 3: Pollution and Protection of the Seas-Radioactive Materials, Heavy Metals and Oil, John Wiley and Sons, New York, NY.

Workman, I.K. and C.E. Jones, 1979. "Determine Effects of Field Discharges on Species Composition and Abundance of Pelagic Fishes and Demersal Fishes and Macro-Crustaceans in the Oil Field" pp. 2.3.5-1 - 2.3.5-149, in: W.B. Jackson (ed) Environmental Assessment of an Active Oil Field in the Northwest Gulf of Mexico 1977-1978. Volume II Data Management and Biological Investigation. U.S. Department of Commerce, PB80-165970.

Zien-Eldin, Z.P. and P.M. Keney, 1979, "Bioassay of Buccaneer Oil Field effluent with Penaeid Shrimp", pp. 2.3.4-1 -2.3.4-25, in: W.B. Jackson (ed) Environmental Assessment of an Active Oil Field in the Northwest Gulf of Mexico 1977-1978. Volume II Data Management and Biological Investigation, U.S. Department of Commerce, PB80-165970. 


\section{APPENDIX A}

SPECIES LISTS FOR THE GULF OF MEXICO

(modified after Darnell and Schmidly, 1988)

page

Table A-1. Common nekton species of the Texas-Louisiana continental shelf.

Table A-2. Common demersal species of the Texas-Louisiana continental shelf $(0-200 \mathrm{~m})$.

Table A-3. Common demersal species of the Texas-Louisiana upper continental slope (200-500 m).

Table A-4. Some of the major macrofaunal taxa reported from the Texas-Louisiana continental shelf and slope.

Table A-5. Depth-related faunal assemblages of the TexasLouisiana continental shelf and upper slope based upon the larger benthic invertebrates..

Table A-6. Partial list of algae and invertebrates reported from drilling rigs and platforms of the Texas-Louisiana continental shelf

Table A-7. Fish species reported around drilling rigs and platforms of the Texas-Louisiana continental shelf. 
Table A-1. Common nekton species of the Texas-Louisiana continental shelf.

\section{INVERTEBRATES}

Medusae

Cyanea capillata

Dactylometra quinquecirma

Stomolophus meleagris

lion's mane

sea nettle

cabbage head

Cephalopods

Doryteuthis plei

Loligo pealei

Lolliguncula brevis

arrow squid

common squid

little squid

\section{CARTILAGINOUS FISHES}

\section{Carcharhinidae}

Carcharhinus brevipinna

Carcharhinus falciformis

Carcharhinus isodon

Carcharhinus leucas

Carcharhinus limbatus

Galeocerdo cuvieri

Mustelis canis

Rhizoprinodon terraenovae

\section{Sphyrnidae \\ Sphyma lewini \\ Sphyma tiburo}

Myliobatidae

Rhinoptera bonasus

Mobulidae

Manta birostris

spinner shark

silky shark

finetooth shark

bull shark

blacktip shark

tiger shark

smooth dogfish

Atlantic sharpnose shark

scalloped hammerhead

bonnethead

cownose ray

BONY FISHES

\section{Elopidae}

Elops saurus

Megalops atlanticus

ladyfish

tarpon

\section{Clupeidae}

Brevoortia gunteri

Brevoortia patronus

Harengula jaguana

Opisthonema oglinum

Atlantic manta

finescale menhaden

Gulf menhaden

scaled sardine

Atlantic thread herring 
Table A-1 (continued).

\begin{tabular}{|c|c|}
\hline $\begin{array}{l}\text { Engraulidae } \\
\text { Anchoa hepsetus } \\
\text { Anchoa mitchilli }\end{array}$ & $\begin{array}{l}\text { striped anchovy } \\
\text { bay anchovy }\end{array}$ \\
\hline $\begin{array}{l}\text { Exocoetidae } \\
\text { Cypselurus cyanopterus } \\
\text { Hirundichthys rondeleti } \\
\text { Hyporhampus unifasciatus }\end{array}$ & $\begin{array}{l}\text { margined flying fish } \\
\text { blackwing flyingfish } \\
\text { halfbeak }\end{array}$ \\
\hline $\begin{array}{l}\text { Belonidae } \\
\text { Strongylura marina }\end{array}$ & Atlantic needlefish \\
\hline $\begin{array}{l}\text { Atherinidae } \\
\text { Membras martinica } \\
\text { Menidia peninsulae }\end{array}$ & $\begin{array}{l}\text { rough silverside } \\
\text { tidewater silverside }\end{array}$ \\
\hline $\begin{array}{l}\text { Pomatomidae } \\
\text { Pomatomus saltatrix }\end{array}$ & bluefish \\
\hline $\begin{array}{l}\text { Rachycentridae } \\
\text { Rachycentron canadum }\end{array}$ & cobia \\
\hline $\begin{array}{l}\text { Echeneidae } \\
\text { Echeneis naucrates }\end{array}$ & sharksucker \\
\hline $\begin{array}{l}\text { Carangidae } \\
\text { Camax hippos } \\
\text { Camax latus } \\
\text { Chloroscombrus chrysurus } \\
\text { Decapterus punctatus } \\
\text { Oligoplites sarus } \\
\text { Selene setapinnis } \\
\text { Seriola dumerili } \\
\text { Seriola zonata } \\
\text { Trachinotus carolinus }\end{array}$ & $\begin{array}{l}\text { crevalle jack } \\
\text { horse-eye jack } \\
\text { Atlantic bumber } \\
\text { round scad } \\
\text { leatherjacket } \\
\text { Atlantic moonfish } \\
\text { greater amberjack } \\
\text { banded rudderfish } \\
\text { Florida pompano }\end{array}$ \\
\hline $\begin{array}{l}\text { Coryphaenidae } \\
\text { Coryphaena equisetis } \\
\text { Coryphaena hippurus }\end{array}$ & $\begin{array}{l}\text { pompano dolphin } \\
\text { dolphin }\end{array}$ \\
\hline $\begin{array}{l}\text { Mugilidae } \\
\text { Mugil cephalus } \\
\text { Mugil curema }\end{array}$ & $\begin{array}{l}\text { striped mullet } \\
\text { white mullet }\end{array}$ \\
\hline $\begin{array}{l}\text { Sphyraenidae } \\
\text { Sphyraena barracuda } \\
\text { Sphyraena guachancho }\end{array}$ & $\begin{array}{l}\text { great barracuda } \\
\text { guaguanche }\end{array}$ \\
\hline
\end{tabular}


Table A-1 (continued).

\begin{tabular}{|c|c|}
\hline $\begin{array}{l}\text { Polynemidae } \\
\text { Polydactylus octonemus }\end{array}$ & Atlantic threadfin \\
\hline $\begin{array}{l}\text { Scombridae } \\
\text { Acanthocybium solanderi } \\
\text { Euthynnus alletteratus } \\
\text { Scomberomorus cavalla } \\
\text { Scomberomorus maculatus } \\
\text { Thunnus albacares } \\
\text { Thunnus atlanticus }\end{array}$ & $\begin{array}{l}\text { wahoo } \\
\text { little tunny } \\
\text { king mackerel } \\
\text { Spanish mackerel } \\
\text { yellowfin tuna } \\
\text { blackfin tuna }\end{array}$ \\
\hline $\begin{array}{l}\text { Xiphiidae } \\
\text { Xiphias gladius }\end{array}$ & swordfish \\
\hline $\begin{array}{l}\text { Istiphoridae } \\
\text { Istiophorus platypterus } \\
\text { Makaira nigricans } \\
\text { Tetrapterus albidus }\end{array}$ & $\begin{array}{l}\text { sailfish } \\
\text { blue marlin } \\
\text { white marlin }\end{array}$ \\
\hline $\begin{array}{l}\text { Stromateidae } \\
\text { Peprilus alepidotus } \\
\text { Peprilus burti }\end{array}$ & $\begin{array}{l}\text { harvestfish } \\
\text { Gulf butterfish }\end{array}$ \\
\hline SEA TURTLES & \\
\hline $\begin{array}{l}\text { Caretta caretta } \\
\text { Lepidochelys kempi }\end{array}$ & $\begin{array}{l}\text { loggerhead } \\
\text { Kemp's ridley }\end{array}$ \\
\hline CETACEANS & \\
\hline $\begin{array}{l}\text { Globicephala macrorhynchus } \\
\text { Kogia breviceps } \\
\text { Stenella plagiodon } \\
\text { Tursiops truncatus }\end{array}$ & $\begin{array}{l}\text { short-finned pilot whale } \\
\text { pygmy sperm whale } \\
\text { Atlantic spotted dolphin } \\
\text { Atlantic bottlenose dolphin }\end{array}$ \\
\hline
\end{tabular}


Table A-2. Common demersal species of the Texas-Louisiana continental shelf (0-200 m).

\section{SQUIDS \\ Loligo peali* \\ Lolliguncula brevis \\ SHRIMP \\ Peneaus aztecus* \\ Peanaeus setiferus* \\ Sicyonia brevirostris \\ Sicyonia dorsalis \\ Solenocera vioscai \\ Trachypenaeus similis \\ Xiphopenaeus kroyeri \\ CRABS \\ Porcellana sayana \\ Raninoides louisianensis \\ Calappa sulcata \\ Callinectes sapidus* \\ Callinectes similis \\ Portunus gibbesi \\ Portunus spinicarpus \\ Portunus spinimanus}

\section{STOMATOPODS}

Squilla chydaea

Squilla empusa

\section{FISHES}

Clupeidae

Brevoortia patronus ${ }^{\star}$

Harengula jaguana

Synodontidae

Synodus foetens

\section{Ariidae}

Arius felis*

\section{Batrachoididae}

Porichthys plectrodon ${ }^{*}$

Ogcocephalidae

Halieutichthys aculeatus

Gadidae

Urophycis floridana

* estuary related species
Gulf menhaden

scaled sardine

inshore lizardfish

hardhead catfish

Atlantic midshipman

pancake batfish

southern hake 
Table A-2 (cont).

\begin{tabular}{|c|c|}
\hline $\begin{array}{l}\text { Serranidae } \\
\text { Centropristis philadelphica } \\
\text { Diplectum bivittatum } \\
\text { Diplectum formosum } \\
\text { Serranus atrobranchus }\end{array}$ & $\begin{array}{l}\text { rock sea bass } \\
\text { dwarf sand perch } \\
\text { sand perch } \\
\text { blackear bass }\end{array}$ \\
\hline $\begin{array}{l}\text { Carangidae } \\
\text { Chloroscombrus chrysurus } \\
\text { Selena setapinnis } \\
\text { Trachurus lathami }\end{array}$ & $\begin{array}{l}\text { Atlantic bumber } \\
\text { Atlantic moonfish } \\
\text { rough scad }\end{array}$ \\
\hline $\begin{array}{l}\text { Lujanidae } \\
\text { Lutjanus campechanus } \\
\text { Pristipomoides aquilonaris } \\
\text { Rhomboplites aurorubens }\end{array}$ & $\begin{array}{l}\text { red snapper } \\
\text { wenchman } \\
\text { vermilion snapper }\end{array}$ \\
\hline $\begin{array}{l}\text { Haemulidae } \\
\text { Orthopristis chrysoptera* }\end{array}$ & pigfish \\
\hline $\begin{array}{l}\text { Sparidae } \\
\text { Lagodon rhomboides } \\
\text { Stenotomus caprinus }\end{array}$ & $\begin{array}{l}\text { pinfish } \\
\text { longspine porgy }\end{array}$ \\
\hline $\begin{array}{l}\text { Sciaenidae } \\
\text { Cynoscion arenarius* } \\
\text { Cynoscion nothus } \\
\text { Larimus fasciatus } \\
\text { Leiostomus xanthurus* } \\
\text { Menticimhs americanus } \\
\text { Micropogonias undulatus* }\end{array}$ & $\begin{array}{l}\text { sand seatrout } \\
\text { silver seatrout } \\
\text { banded drum } \\
\text { spot } \\
\text { southern kingfish } \\
\text { Atlantic croaker } \\
\text { star drum }\end{array}$ \\
\hline $\begin{array}{l}\text { Mullidae } \\
\text { Mulloidichthys martinicus } \\
\text { Mullus auratus } \\
\text { Upeneus parvus }\end{array}$ & $\begin{array}{l}\text { yellow goatfish } \\
\text { red goatfish } \\
\text { dwarf goatfish }\end{array}$ \\
\hline $\begin{array}{l}\text { Labridae } \\
\text { Hemipteronotus novacula }\end{array}$ & pearly razorfish \\
\hline $\begin{array}{l}\text { Polynemidae } \\
\text { Polydactylus octonemus }\end{array}$ & Atlantic threadfin \\
\hline $\begin{array}{l}\text { Trichiuridae } \\
\text { Trichiurus lepturus }\end{array}$ & Atlantic cutlassfish \\
\hline
\end{tabular}

- estuary related species 
Table A-2. (cont).

\begin{tabular}{|c|c|}
\hline $\begin{array}{l}\text { Stromateidae } \\
\text { Peprilus alepidotus } \\
\text { Peprilus burti }\end{array}$ & $\begin{array}{l}\text { harvestfish } \\
\text { Gulf butterfish }\end{array}$ \\
\hline $\begin{array}{l}\text { Triglidae } \\
\text { Bellator militaris } \\
\text { Prionotus paralatus } \\
\text { Prionotus rubio } \\
\text { Prionotus steamsi } \\
\text { Prionotus tribulus }\end{array}$ & $\begin{array}{l}\text { horned searobin } \\
\text { Mexican searobin } \\
\text { blackfin searobin } \\
\text { shortwing searobin } \\
\text { bighead searobin }\end{array}$ \\
\hline $\begin{array}{l}\text { Bothidae } \\
\text { Ancyclopsetta dilecta } \\
\text { Citharichthys spilopterus* } \\
\text { Cyclopsetta chittendeni } \\
\text { Etropus crossotus } \\
\text { Syacium gunteri } \\
\text { Trichopsetta ventralis }\end{array}$ & $\begin{array}{l}\text { three-eye flounder } \\
\text { bay whiff } \\
\text { Mexican flounder } \\
\text { fringed flounder } \\
\text { shoal flounder } \\
\text { sash flounder }\end{array}$ \\
\hline $\begin{array}{l}\text { Soleidae } \\
\text { Trinectes maculatus }\end{array}$ & hogchoker \\
\hline $\begin{array}{l}\text { Balistidae } \\
\text { Monacanthus hispidus }\end{array}$ & planehead filefish \\
\hline $\begin{array}{l}\text { Tetraodontidae } \\
\text { Lagocephalus laevigatus } \\
\text { Spoeroides parvus }\end{array}$ & $\begin{array}{l}\text { smooth puffer } \\
\text { least puffer }\end{array}$ \\
\hline
\end{tabular}

` estuary related species 
Table A-3. Common demersal species of the Texas-Louisiana upper continental slope (200-500 m).

\begin{tabular}{l} 
SHRIMP \\
Acanthephyra purpurea \\
Bentheogennema intermedia \\
Gennadas valens \\
Heterocarpus ensifer \\
Hymenopenaeus debilis \\
Hymenopenaeus robustus \\
Parapandalis willisi \\
Parapenaeus longirostris \\
Penaeopsis serrata \\
Plesionika tenuipes \\
Solenocera vioscai \\
Systellaspis pellucida \\
GALATHEIDS \\
Munida forceps \\
Munida longipes \\
CRABS \\
Acanthocarpus alexandri \\
Bathyplax typhla \\
Benthochascon schmitti \\
Cyclodomipoe antennaria \\
Ethusa macrophthalma \\
Lyreidus bairdii \\
Myropsis quinquespinosa \\
Portunus spinicarpus \\
Pyromaia arachna \\
Raninoides louisianensis \\
Thalassoplax angusta \\
FISHES \\
Ancyclopsetta dilecta \\
Benbrops anatirostris \\
Benbrops gobioides \\
Coelorynchus caribbaeus \\
Coelorynchus coelorhynchus \\
Dibranchus atlanticus \\
Halieuticthys aculeatus \\
Hymenocephalus italicus \\
Parasudis truculenta \\
Peristedion greyae \\
Poecilopsetta beani \\
Pontinus longispinis \\
Pristipomoides aquilonaris \\
Steindachneria argentea \\
Trichopsetta ventralis \\
Urophycis cirrata \\
Urophycis regia \\
Ventrifossa occidentalis \\
\hline
\end{tabular}


Table A-4. Some of the major macrofaunal taxa reported from the TexasLouisiana continental shelf and slope.

\begin{tabular}{|c|c|}
\hline PORIFERA & $\begin{array}{r}\text { MOLLUSCA } \\
\text { Gastropoda }\end{array}$ \\
\hline CNIDARIA & Bivalvia \\
\hline $\begin{array}{l}\text { Hydrozoa } \\
\text { Scvphozoa }\end{array}$ & Scaphopoda \\
\hline $\begin{array}{l}\text { Anthozoa } \\
\text { Actinaria } \\
\text { Alcyonaria } \\
\text { Scleractinia }\end{array}$ & $\begin{array}{l}\text { ARTHROPOD } \\
\text { Acarina } \\
\text { Ostracoda } \\
\text { Copepoda } \\
\text { Mysidacea }\end{array}$ \\
\hline NEMERTA & $\begin{array}{l}\text { Cumacea } \\
\text { Tanaidacea }\end{array}$ \\
\hline $\begin{array}{l}\text { ASCHELMINTHES } \\
\text { Kinorhyncha } \\
\text { Nemadoda } \\
\text { Priapulida }\end{array}$ & $\begin{array}{l}\text { Isopoda } \\
\text { Amphipoda } \\
\text { Decapoda }\end{array}$ \\
\hline $\begin{array}{l}\text { LOPHOPHORA } \\
\text { Brachiopoda } \\
\text { Bryozoa } \\
\text { Phoronida }\end{array}$ & $\begin{array}{l}\text { ECHINODERM } \\
\text { Echinoidea } \\
\text { Holothuroidea } \\
\text { Ophiuroidea }\end{array}$ \\
\hline & POGONOPHORA \\
\hline ECHIURIDA & CHORDATA \\
\hline SIPUNCULIDA & $\begin{array}{r}\text { Urochordata } \\
\text { Ascidiacea }\end{array}$ \\
\hline $\begin{array}{l}\text { ANNELIDA } \\
\text { Oligochaeta } \\
\text { Polychaeta }\end{array}$ & \\
\hline
\end{tabular}


Table A-5. Depth-related faunal assemblages of the Texas-Louisiana continental shelf and upper slope based upon the larger benthic invertebrates.

\section{INNER SHELF ASSEMBLAGE}

Cnidaria

Renilla mlleri

Astrangia astreiformis

Palythoa texaensis

\section{Annelida}

Diopatra cuprea

Onuphis eremita oculata

\section{Gastropoda}

Architectonica nobilis

Polinices duplicatus

Phalium granulatum

Ihais haemostoma canaliculata

Anachis obesa

Cantharus cancellarius

Busycon spiratum plagosum

Nassarius acutus

Oliva sayana

Olivella mutica

Terebra dislocata

Terebra protexta

\section{Bivalvia}

Nuculana concentrica

Anadara ovalis

Anadara transversa

Noetia ponderosa

Atrina serrata

Dinocardium robustum

Dosinia discus

Corbula swiftiana
Natantia

Penaeus aztecus

Penaeus setiferus

Sicyonia brevirostris

Sicyonia dorsalis

Trachypenaeus similis

\section{Reptantia}

Pagurus pollicaris

Persephona aquilonaris

Persephona crinata

Persephona punctata

Calappa sulcata

Hepatus epheliticus

Callinectes sapidus

Callinectes similis

Portunus gibbesi

Portunus spinimanus

Libina emarginata

Stomatopoda

Squilla emousa

Echinodermata

Luidia clathrata

Ophioleopis elegans

Mellita quinquiesperforata 
Table A-5. (continued)

\section{PRO-DELTA FAN ASSEMBLAGE}

\section{Cnidaria}

Renilla mulleri

Gastropoda

Cantharus cancellarius

Nassarius acutus

Bivalvia

Nuculana concentrica

Macoma tageliformis

Abra loica

\section{Natantia}

Peneaus aztecus

Peanaeus setiferus

Sicyonia dorsalis

Trachypenaeus similis

\section{Reptantia}

Persephona crinata

Callinectes similis

Portunus gibbesi

Portunus spinimanus

Stomatopoda

Squilla empusa

\section{INTERMEDIATE SHELF ASSEMBLAGE}

Annelida

Diopatra cuprea

\section{Gastropoda}

Strombus alatus

Distorsio clathrata

Tonna galea

Murex fulvescens

Busycon contrarium

Fasciolaris lilium hunteri

Conus austini

Polystira albida

Pleurobrachea hedgpethi

Natantia

Peneaus aztecus

Peanaeus setiferus

Sicyonia brevirostris

Sicyonia dorsalis

Trachypenaeus similis
Reptantia

Petrochirus diogenes

Persephona crinata

Calappa sulcata

Hepatus epheliticus

Callinectes similis

Portunus gibbesi

Portunus spinicarpus

Portunus spinimanus

Anasimus latus

Libina emarginata

Parthenope serrata

Stomatopoda

Squilla chydaea

Squilla empusa

Echinodermata

Luidia altemata

Luidia clathrata

Astropecten duplicatus

Ophiolepis elegans

Clypeaster ravenelli

Encope michelini

Echinaster sp.

Stylocidaris affinis 
Table A-5. (continued)

OUTER SHELF ASSEMBLAGE

\section{Gastropoda}

Turritella exoleta

Distorsio clathrata macgintyj

Polystira albida

\section{Bivalvia}

Anadara baughmani

Anadara floridana

Amusium papyraceus

Argopecten gibbus

Pitar cordatus

Verticordia omata

Natantia

Parapenaeus longirostris

Peneaus aztecus

Sicyonia brevirostris

Trachypenaeus similis
Reptantia

Munida forceps

Raninoides louisianensis

Myropsis quinquespinosa

Calappa springeri

Calappa sulcata

Portunus spinicarpus

Anasimus latus

Leiolambrus nitidus

Stomatopoda

Squilla chydaea

Echniodermata

Astropecten cingulatus

Astropecten duplicatus

Brissopsis atlantica

Echinocardium fulvescens

UPPER SLOPE ASSEMBLAGE

Cnidaria

sea anemone (unidentified)

\section{Annelida}

Protula tubularia

Gastropoda

Sconsia striata

Murex beauii

Bivalvia

Yoldia solenoides

Limopsis sulcata

Cyclopecten nanus

Cyclocardia armilla

Nemocardium perambile

Natantia

Parapenaeus longirostris

Solenociera vioscai

Hymenopenaeus tropicalis

\section{Reptantia}

Munida forceps

Raninoides louisianensis

Myropsis quinquespinosa

lliacantha subglobosa

Pyromaia arachna

Acanthocarpus alexandri

Calappa sulcata

Portunus spinicarpus

Thalassoplax angusta

Anasimus latus

Stenocionops spinimana

Parthenope agona

Stomatopoda

Squilla chydaea

Echinodermata

Anthenoides piercei

Luidia elegans

Astropecten nitidus

Chieraster echinulatus

Echinocardium fulvescens

Brissopsis alta

Brissopsis atlantica 
Table A-6. Partial list of algae and invertebrates reported from drilling rigs and platforms of the Texas-Louisiana continental shelf.

\section{ALGAE}

Cyanophyta - Microcoleus, Oscillatoria, Schizothrix

Rhodophyta - Acrochaetum, Callithamnion, Ceramium, Polysiphonia

Phaeophyta - Ectocarpus, Giffordia, Sargassum

Chlorophyta - Bryopsis, Chaetomorpha, Cladophora, Enteromorpha

\section{INVERTEBRATES}

Porifera - Cliona, Haliclona, Halichondria, Verongia

Cnidaria

Hydrozoa - Aglaophenia, Bougainvillea, Obelia, Tubularia

Anthoza - Astrangea, Leptogorgia, Oculina, Telesto

Nemerteans

Platyhelminthes - Leptoplana

Bryozoans - Acanthodesmia, Bugula, Membranipora

Sipunculids

Annelida

Polychaetes - Eunice, Haplosyllus, Neanthes, Nereis

Mollusks

Gastropods - Cantharus, Crepidula, Murex, Thais

Bivalves - Arca, Crassostrea, Isognomon, Ostrea

Pycnogonids - Tanystylum

\section{Crustaceans}

Copepods - Acartia, Labidocera

Cirripedes - Balanus, Lepas, Megabalanus

Amphipods - Caprella, Corophium, Jassa, Stenothoe

Tanaids - Tanais

Isopods - Limnoria, Sphaeroma

Decapods - Callinectes, Dromidia, Eurypanopeus, Hexapaneopeus, Menippe, Neopanope, Pachygrapsus, Pagurus,

Panopeus, Panulirus, Petrochirus, Pilumus,

Porcellana, Portunus, Stenorhynchus, Synalpheus

Echinoderms - Arbacea, Ophiactis, Ophiothrix

Urochordata

Ascidiaceans - Enterogona 
Table A-7. Fish species reported around drilling rigs and platforms of the TexasLouisiana a continental shelf.

\begin{tabular}{|c|c|}
\hline $\begin{array}{l}\text { Orectolobidae } \\
\text { Ginglymostoma cirratum }\end{array}$ & $\begin{array}{l}\text { carpet sharks } \\
\text { nurse shark }\end{array}$ \\
\hline $\begin{array}{l}\text { Sphymidae } \\
\text { Sphyma americana }\end{array}$ & $\begin{array}{l}\text { hammerhead sharks } \\
\text { scalloped hammerhead }\end{array}$ \\
\hline $\begin{array}{l}\text { Dasyatidae } \\
\text { Dasyatis americana }\end{array}$ & $\begin{array}{l}\text { stingrays } \\
\text { southern stingray }\end{array}$ \\
\hline $\begin{array}{l}\text { Clupeidae } \\
\text { Harengula jaguana } \\
\text { Sardinella aurita }\end{array}$ & $\begin{array}{l}\text { herrings } \\
\text { scaled sardine } \\
\text { Spanish sardine }\end{array}$ \\
\hline $\begin{array}{l}\text { Serranidae } \\
\text { Epinephelus adscensionis } \\
\text { Epinephelus itajara } \\
\text { Epinephelus nigritus } \\
\text { Mycteroperca phenax } \\
\text { Mycteroperca rubra } \\
\text { Paranthias furcifer } \\
\text { Serranus subligarius }\end{array}$ & $\begin{array}{l}\text { sea basses } \\
\text { rock hind } \\
\text { Jewfish } \\
\text { Warsaw grouper } \\
\text { scamp } \\
\text { comb grouper } \\
\text { Creole-fish } \\
\text { belted sandfish }\end{array}$ \\
\hline $\begin{array}{l}\text { Grammistidae } \\
\text { Rypticus maculatus }\end{array}$ & $\begin{array}{l}\text { soapfishes } \\
\text { whitespotted soapfish }\end{array}$ \\
\hline $\begin{array}{l}\text { Priacanthidae } \\
\text { Pricanthus arenatus }\end{array}$ & $\begin{array}{r}\text { bigeyes } \\
\text { bigeye }\end{array}$ \\
\hline $\begin{array}{l}\text { Apogonidae } \\
\text { Apogon maculatus }\end{array}$ & $\begin{array}{l}\text { cardinaifishes } \\
\text { flamefish }\end{array}$ \\
\hline $\begin{array}{l}\text { Pomatomidae } \\
\text { Pomatomus saltatrix }\end{array}$ & $\begin{array}{l}\text { bluefishes } \\
\text { bluefish }\end{array}$ \\
\hline $\begin{array}{l}\text { Rachycentridae } \\
\text { Rachycentron canadum }\end{array}$ & $\begin{array}{r}\text { cobias } \\
\text { cobia }\end{array}$ \\
\hline $\begin{array}{l}\text { Carangidae } \\
\text { Caranx crysos } \\
\text { Caranx hippos } \\
\text { Caranx latus } \\
\text { Chloroscombrus chrysurus } \\
\text { Decapterus punctatus } \\
\text { Elagatis bipinnulata } \\
\text { Selene setapinnis } \\
\text { Selene vomer } \\
\text { Seriola dumerili } \\
\text { Seriola rivoliana } \\
\text { Trachurus lathami }\end{array}$ & $\begin{array}{l}\text { jacks } \\
\text { blue runner } \\
\text { crevalle jack } \\
\text { horse-eye jack } \\
\text { Atlantic bumber } \\
\text { round scad } \\
\text { rainbow runner } \\
\text { Atlantic moonfish } \\
\text { lookdown } \\
\text { greater amberjack } \\
\text { almaco jack } \\
\text { rough scad }\end{array}$ \\
\hline
\end{tabular}


Table A-7. (continued).

\begin{tabular}{|c|c|}
\hline $\begin{array}{l}\text { Coryphaenidae } \\
\text { Coryphaena hippurus }\end{array}$ & $\begin{array}{r}\text { dolphins } \\
\text { dolphin }\end{array}$ \\
\hline $\begin{array}{l}\text { Lutjanidae } \\
\text { Lutjanus campechanus } \\
\text { Lutjanus cyanopterus } \\
\text { Lutjanus griseus } \\
\text { Lutjanus synagris } \\
\text { Ocyurus chrysurus } \\
\text { Rhomboplites aurorubens }\end{array}$ & $\begin{array}{l}\text { snappers } \\
\text { red snapper } \\
\text { cubera snapper } \\
\text { gray snapper } \\
\text { lane snapper } \\
\text { yellowtail snapper } \\
\text { vermiliom snapper }\end{array}$ \\
\hline $\begin{array}{l}\text { Haemulidae } \\
\text { Haemulon aurolineatum }\end{array}$ & $\begin{array}{l}\text { grunts } \\
\text { tomtate }\end{array}$ \\
\hline $\begin{array}{l}\text { Sparidae } \\
\text { Archosargus probatocephalus }\end{array}$ & $\begin{array}{l}\text { porgies } \\
\text { sheepshead }\end{array}$ \\
\hline $\begin{array}{l}\text { Sciaenidae } \\
\text { Cynoscion arenarius } \\
\text { Cynoscion nebulosus } \\
\text { Equetus umbrosus } \\
\text { Micropogonias undulatus }\end{array}$ & $\begin{array}{l}\text { drums } \\
\text { sand seatrout } \\
\text { spotted seatrout } \\
\text { cubbyu } \\
\text { Atlantic croaker }\end{array}$ \\
\hline $\begin{array}{l}\text { Kyphosiadae } \\
\text { Kyphosus sectatrix }\end{array}$ & $\begin{array}{l}\text { sea chubs } \\
\text { Bermuda chub }\end{array}$ \\
\hline $\begin{array}{l}\text { Ephippidae } \\
\text { Chaetodipterus faber }\end{array}$ & $\begin{array}{l}\text { spadefishes } \\
\text { Atlantic spadefish }\end{array}$ \\
\hline $\begin{array}{l}\text { Chaetodontidae } \\
\text { Chaetodnon ocellatus }\end{array}$ & $\begin{array}{l}\text { butterfly fishes } \\
\text { spotfin butterflyfish }\end{array}$ \\
\hline $\begin{array}{l}\text { Pomacanthidae } \\
\text { Holacanthus bermudensis } \\
\text { Holacanthus ciliaris } \\
\text { Holacanthus tricolor } \\
\text { Pomacanthus arcuatus } \\
\text { Pomacanthus paru }\end{array}$ & $\begin{array}{l}\text { angelfishes } \\
\text { blue angelfish } \\
\text { queen angelfish } \\
\text { rock beauty } \\
\text { gray angelfish } \\
\text { French angelfish }\end{array}$ \\
\hline $\begin{array}{l}\text { Pomacentridae } \\
\text { Abudefduf saxatilis } \\
\text { Chromis multilineatus } \\
\text { Pomacentrus variabilis }\end{array}$ & $\begin{array}{l}\text { damselfishes } \\
\text { sergeant major } \\
\text { brown chromis } \\
\text { cocoa damselfish }\end{array}$ \\
\hline $\begin{array}{l}\text { Cirrhitidae } \\
\text { Amblycirnhitus pinos }\end{array}$ & $\begin{array}{l}\text { hawkfishes } \\
\text { redspotted hawkfish }\end{array}$ \\
\hline $\begin{array}{l}\text { Labridae } \\
\text { Bodianus pulchellus } \\
\text { Bodianus rufus } \\
\text { Thalassoma bifasciatum }\end{array}$ & $\begin{array}{l}\text { wrasses } \\
\text { spotted hogfish } \\
\text { Spanish hogfish } \\
\text { bluehead }\end{array}$ \\
\hline
\end{tabular}


Table A-7. (continued).

\begin{tabular}{ll}
\hline $\begin{array}{l}\text { Sphyraenidae } \\
\text { Sphyraene barracuda }\end{array}$ & $\begin{array}{l}\text { barracuda } \\
\text { great barracuda }\end{array}$ \\
$\begin{array}{l}\text { Blenniidae } \\
\text { Hypleurochilus geminatus }\end{array}$ & $\begin{array}{l}\text { combtooth blennies } \\
\text { crested blenny } \\
\text { Hypleurochiuis springeri }\end{array}$ \\
$\begin{array}{l}\text { Parablennius marmospotted blenny } \\
\text { Scartella cristata }\end{array}$ & $\begin{array}{l}\text { seaweed blenny } \\
\text { molly miller }\end{array}$ \\
Acanthuridae & surgeonfishes \\
Acanthurus coeruleus & blue tang \\
& mackerels \\
Scombridae & little tunny \\
Euthynnus alleteratus & king mackerel \\
Scomberomorus cavalla & leatherjackets \\
& orange filefish \\
Balistidae & scrawled filefish \\
Aluterus schoepfi & gray triggerfish \\
Aluterus scriptus & queen triggerfish \\
Balistes capriscus & orangespotted filefish \\
Balistes vetula & ocean triggerfish \\
Cantherhines pullus & planehead filefish \\
Cantherhines suffiamen & puffers \\
Monacanthus hispidus & sharpnose puffer \\
\hline
\end{tabular}

